\title{
Profits and Balance Sheet Developments at U.S. Commercial Banks in 1996
}

William R. Nelson and Ann L. Owen, of the Board's Division of Monetary Affairs, prepared this article. Thomas C. Allard assisted in the preparation of the data, and Amy M. Tucker provided research assistance.

U.S. commercial banks had another very good year in 1996. Profits posted strong growth, preserving the high levels of return on equity and return on assets that have prevailed over the past four years (chart 1). Helping to boost profits were continued strong growth of interest-earning assets, a slight widening of the net interest margin, significant gains in noninterest income, and continued containment of noninterest expense (table 1). Return on assets edged up despite a slight increase in provisioning for loan and lease losses relative to assets. Delinquency and charge-off rates stayed low for business loans but climbed throughout the year for consumer loans. ${ }^{1}$

Commercial banks generally were willing lenders last year, helping to support the strong advance in U.S. economic activity. In fact, increased loan volume was the main contributor to the increase in assets; banks' holdings of securities rose only slightly. Loan growth was funded primarily with managed liabilities.

Bank stock prices rose more rapidly than prices in the stock market as a whole, and many bank holding companies substantially increased their dividends and their stock repurchases. Banks paid out three-fourths

1. Except where otherwise indicated, data in this article are from the quarterly Reports of Condition and Income (Call Reports) for insured domestic commercial banks. The data consolidate information from foreign and domestic offices and have been adjusted to take account of mergers. Size categories, based on assets at the start of each quarter, are as follows: the ten largest banks, large banks (those ranked 11 through 100 by size), medium-sized banks (those ranked 101 through 1,000 by size), and small banks (those not among the largest 1,000 banks). At the start of the fourth quarter of 1996, each of the ten largest banks had assets of more than approximately $\$ 50$ billion, each large bank had assets between approximately $\$ 7$ billion and $\$ 50$ billion, each medium-sized bank had assets between approximately $\$ 300$ million and $\$ 7$ billion, and each small bank had assets of less than approximately $\$ 300$ million. Many of the data series reported here begin in 1985 because the Call Report was significantly revised at the start of that year. Data shown may not match data published in earlier years because of revisions. In the tables, components may not sum to totals because of rounding. of their net income as dividends in 1996, up from two-thirds in the previous two years. Even so, the ratio of capital to total assets increased slightly, and virtually all bank assets were at well-capitalized banks.

\section{BALANCE SHEET DEVELOPMENTS}

Bank assets expanded further in 1996, though at a somewhat slower pace than in 1995 (table 2). ${ }^{2}$ Increases in loans and leases, particularly to businesses, accounted for most of the growth. On the liability side of the balance sheet, core deposits grew more slowly than managed liabilities for the fourth consecutive year, with large time deposits an increasingly important source of funds.

2. Since 1994, reported bank assets have included the market value of derivatives contracts. As required by Financial Accounting Standards Board Interpretation No. 39 (FIN 39), derivatives used for trading purposes that have positive value are recorded as assets and those that have negative value as liabilities. Before 1994, banks netted the values of derivatives across counterparties. Total assets excluding the effects of FIN 39 can be approximately determined from the data reported in table A. 2 by reducing assets by the revaluation losses on off-balance-sheet items. For a discussion of this issue, see William B. English and Brian K. Reid, "Profits and Balance Sheet Developments at U.S. Commercial Banks in 1994," Federal Reserve Bulletin, vol. 81 (June 1995), pp. 548-49.

1. Measures of commercial bank profitability, 1970-96

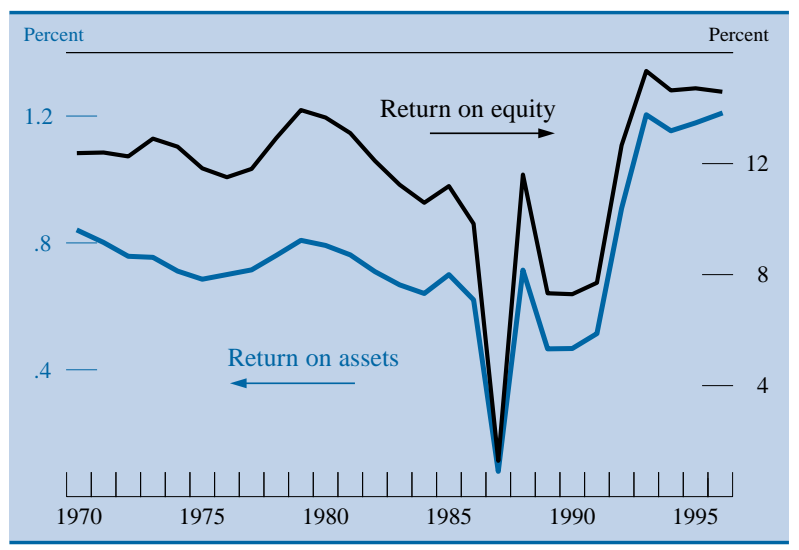

Note. The data are annual. 


\section{Loans to Businesses}

The value of commercial and industrial (C\&I) loans on banks' balance sheets grew about 71/4 percent last year-somewhat less than in the preceding two years but still a sizable increase. According to the Federal Reserve's quarterly Senior Loan Officer Opinion Survey on Bank Lending Practices (LPS), the demand for C\&I loans remained high throughout the year (chart 2). ${ }^{3}$ Banks attributed the strong demand in part to their customers' needs to finance inventories and plant and equipment. Demand was also boosted by heavy merger and acquisition activity, which in many cases resulted in a need to finance the retirement of the acquired firm's equity.

Not only were banks willing to meet the strong demand for C\&I loans, but they encouraged it by easing lending terms over the course of the year. Respondents to the LPS reported having lowered the cost of credit lines, narrowed spreads of rates charged on business loans over base rates, and eased loan covenants, particularly for large firms. In contrast, respondents to a second survey, the Federal Reserve's quarterly Survey of Terms of Bank Lending to Business, which involves a larger sample of banks, indicated that spreads on loans of all sizes changed very little during $1996 .{ }^{4}$ On average, how-

3. About sixty domestic commercial banks from the twelve Federal Reserve Districts are surveyed by the LPS. Most of them are large: As of December 31, 1996, their combined assets totaled \$1.3 trillion, about one-third of the combined assets of all domestic commercial banks.

4. The Survey of Terms of Bank Lending to Business collects data on lending rates from a sample of more than 300 commercial banks. These banks accounted for 64 percent of the dollar value of C\&I loans outstanding at the end of 1996. Data are collected on the terms of C\&I loans made by these banks during the first full week of the middle month of each quarter.
2. Net percentage of selected commercial banks that experienced increased demand for commercial and industrial loans, by size of firms seeking loans, 1992-96

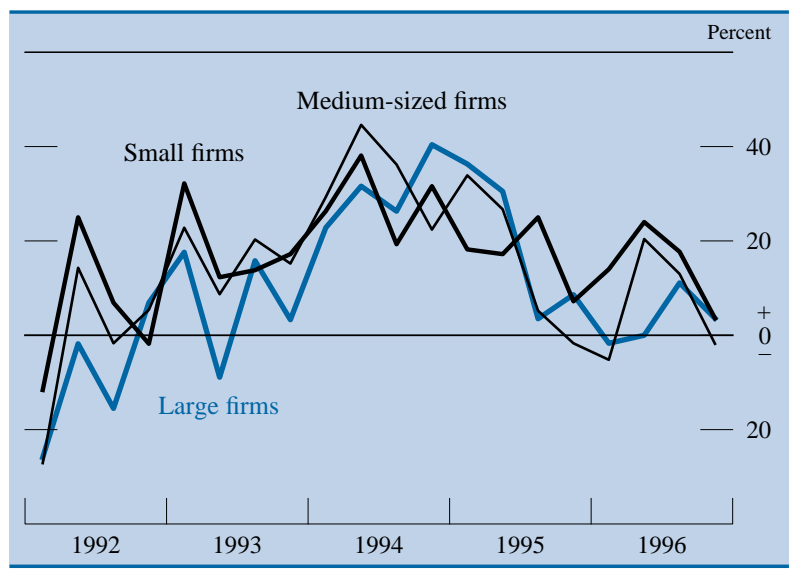

Note. The data are quarterly. Net percentage is the percentage of banks reporting an increase less the percentage reporting a decrease. The definition for firm size suggested for, and generally used by, survey respondents is that medium firms are those with sales between $\$ 50$ million and $\$ 250$ million.

Source. Senior Loan Officer Opinion Survey on Bank Lending Practices.

ever, spreads in this second survey were narrower last year than in 1995, particularly for large loans (chart 3).

More aggressive competition from other commercial bank and nonbank lenders was an important factor influencing the LPS respondents that eased standards or terms for C\&I loans. The bond market was one source of competition, as yields on corporate bonds, especially below-investment-grade borrowing instruments, were low by historical standards compared with rates on Treasury securities. Even so, by pricing relatively aggressively, commercial banks were able to capture a larger share of the business financing market. However, the share of total credit market debt of nonfinancial businesses provided by

1. Selected income and expense items

Percentage of average net consolidated assets

\begin{tabular}{|c|c|c|c|c|c|c|c|c|c|}
\hline \multirow[b]{2}{*}{ Item } & \multirow[b]{2}{*}{1991} & \multirow[b]{2}{*}{1992} & \multirow[b]{2}{*}{1993} & \multirow[b]{2}{*}{1994} & \multirow[b]{2}{*}{1995} & \multirow[b]{2}{*}{1996} & \multicolumn{3}{|c|}{ Annual average } \\
\hline & & & & & & & $1985-92$ & $1993-96$ & $\begin{array}{c}\text { Change, } \\
1985-92 \text { to } \\
1993-96\end{array}$ \\
\hline Net interest income & 3.61 & 3.90 & 3.90 & 3.79 & 3.73 & 3.76 & 3.55 & 3.79 & .24 \\
\hline Noninterest income & 1.79 & 1.95 & 2.13 & 2.00 & 2.02 & 2.19 & 1.56 & 2.08 & .52 \\
\hline Noninterest expense & 3.73 & 3.87 & 3.94 & 3.76 & 3.65 & 3.73 & 3.47 & 3.77 & .30 \\
\hline 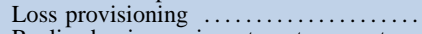 & 1.03 & .78 & .47 & .28 & .30 & .38 & .90 & .36 & -.54 \\
\hline $\begin{array}{l}\text { Realized gains on investment account } \\
\text { securities }\end{array}$ & 09 & .11 & .09 & -.01 & 01 & .03 & .06 & .03 & -.03 \\
\hline $\begin{array}{l}\text { Income before taxes and extraordinary } \\
\text { items }\end{array}$ & .73 & 1.32 & 1.70 & 1.74 & 1.81 & 1.86 & .81 & 1.78 & .97 \\
\hline $\begin{array}{l}\text { Taxes and extraordinary items } \\
\text { Net income (return on assets) }\end{array}$ & .22 & $\begin{array}{l}.41 \\
.91\end{array}$ & $\begin{array}{r}.50 \\
1.20\end{array}$ & $\begin{array}{r}.58 \\
1.15\end{array}$ & $\begin{array}{r}.63 \\
1.18\end{array}$ & $\begin{array}{r}.65 \\
1.21\end{array}$ & .25 & $\begin{array}{r}.59 \\
1.19\end{array}$ & .34 \\
\hline Dividends & .45 & .41 & .62 & .73 & .75 & .91 & .40 & .75 & .35 \\
\hline Retained income & .07 & .50 & .59 & .42 & .43 & .29 & .16 & .43 & .27 \\
\hline
\end{tabular}


banks remained well below levels of the early 1980s (chart 4).

The growth of commercial real estate loans picked up to $73 / 4$ percent in 1996 , the third consecutive year in which such lending expanded. Demand was likely stimulated by improving conditions in the commercial real estate market, as seen in declining vacancy rates and rising commercial real estate prices. Still, at the end of 1996, only about 9 percent of bank assets were in the form of commercial real estate loans, down from 111/4 percent in 1991. The change has not been uniform across banks of different sizes, however: The proportion of assets in commercial real estate loans has increased for small banks (from 11 percent in 1991 to $13 \frac{1}{1} 4$ percent in 1996) but has decreased for large banks (from 11/1/4 percent in 1991 to $81 / 2$ percent in 1996).

\section{Loans to Households}

The value of consumer loans on banks' balance sheets increased about 5 percent last year, about half as fast as in 1995. The slowing of growth was likely a result of several factors: an increase in the pace of securitization of consumer loans, which removes loans originated by banks from their balance sheets; a slight weakening of the growth of demand for such loans; and less aggressive pursuit of these loans by banks.

2. Annual rates of growth of balance sheet items, 1987-96

Percent

\begin{tabular}{|c|c|c|c|c|c|c|c|c|c|c|c|}
\hline Item & 1987 & 1988 & 1989 & 1990 & 1991 & 1992 & 1993 & 1994 & 1995 & 1996 & $\begin{array}{c}\text { Мемо: } \\
\text { Dec. } 1996 \\
\text { levels } \\
\text { (billions } \\
\text { of dollars) }\end{array}$ \\
\hline Assets & 2.00 & 4.33 & 5.35 & 2.64 & 1.33 & 2.20 & 5.67 & 8.08 & 7.60 & 6.13 & 4,555 \\
\hline Interest-earning assets & 3.08 & 4.04 & 5.61 & 2.23 & 1.98 & 2.55 & 6.54 & 5.31 & 7.75 & 5.70 & 3,935 \\
\hline Loans and leases (net) & 3.00 & 5.93 & 6.24 & 2.37 & -2.65 & -1.02 & 6.02 & 9.85 & 10.60 & 8.16 & 2,742 \\
\hline Commercial and industrial & -1.95 & 1.84 & 2.97 & -.67 & -9.10 & -4.10 & .52 & 9.34 & 12.25 & 7.29 & 706 \\
\hline Real estate ............. & 16.56 & 12.43 & 12.69 & 8.79 & 2.73 & 1.94 & 6.13 & 7.94 & 8.28 & 5.55 & 1,132 \\
\hline Booked in domestic offices.. & 17.11 & 11.99 & 13.02 & 8.55 & 2.90 & 2.57 & 6.17 & 7.68 & 8.43 & 5.61 & 1,104 \\
\hline Residential & 18.03 & 13.89 & 15.75 & 13.49 & 8.08 & 7.87 & 10.96 & 10.00 & 10.10 & 4.92 & 689 \\
\hline Nonresidential & 16.26 & 10.22 & 10.39 & 3.57 & -2.82 & -3.95 & -.45 & 4.12 & 5.71 & 6.77 & 415 \\
\hline Booked in foreign offices & .84 & 27.03 & 3.00 & 16.65 & -2.34 & -17.80 & 4.66 & 18.37 & 2.80 & 3.17 & 28 \\
\hline Consumer ..................... & 4.55 & 7.64 & 6.18 & $\begin{array}{l}1.03 \\
.38\end{array}$ & -2.55 & -1.53 & $\begin{array}{l}8.00 \\
8.92\end{array}$ & 16.02 & 9.98 & 4.88 & 558 \\
\hline Other loans and leases & -5.33 & -3.09 & $\begin{array}{l}-.10 \\
-.94\end{array}$ & -5.68 & -4.91 & -4.25 & 9.97 & 5.30 & 14.23 & 22.24 & 404 \\
\hline Loan loss reserves and & & & & & & & & & & & \\
\hline unearned income & 44.36 & -4.19 & 10.29 & .35 & -3.79 & -4.79 & -5.89 & -2.20 & .44 & .34 & 58 \\
\hline Securities. . & 4.94 & 3.27 & 5.08 & 8.45 & 16.23 & 12.29 & 12.26 & -4.13 & .60 & .84 & 924 \\
\hline Investment account & 7.51 & 2.93 & 4.04 & 8.19 & 14.42 & 11.44 & 8.09 & -1.71 & -1.54 & -1.12 & 793 \\
\hline U.S. Treasury & .00 & -5.80 & -13.79 & 3.50 & 32.01 & 23.96 & 7.21 & -8.44 & -19.20 & -14.29 & 165 \\
\hline $\begin{array}{l}\text { U.S. government agency and } \\
\text { corporation obligations . }\end{array}$ & 25.46 & & & & & 1277 & & & 6.44 & 362 & 438 \\
\hline Other .................... & 4.43 & -2.46 & -.87 & $\begin{array}{l}2.02 \\
-6.69\end{array}$ & -2.57 & -5.19 & 6.07 & 2.52 & 4.35 & 1.79 & $\begin{array}{l}430 \\
189\end{array}$ \\
\hline Trading account & -23.88 & 8.58 & 20.62 & 11.87 & 38.88 & 21.01 & 51.94 & -20.51 & 18.52 & 14.43 & 132 \\
\hline Other & .24 & -5.82 & 2.49 & -11.69 & 2.82 & 1.57 & -7.89 & 3.25 & 7.65 & -.89 & 269 \\
\hline Non-interest-earning assets & -5.07 & 6.45 & 3.50 & 5.51 & -3.10 & -.31 & -.87 & 30.22 & 6.62 & 8.94 & 620 \\
\hline Liabilities & 2.18 & 4.05 & 5.43 & 2.37 & 1.01 & 1.36 & 5.10 & 8.33 & 7.22 & 5.99 & 4,180 \\
\hline Core deposits & -.76 & 5.48 & 5.75 & 7.58 & 5.25 & 5.09 & 1.49 & -.15 & 3.95 & 4.12 & 2,386 \\
\hline Transaction deposits & -6.04 & 2.65 & .93 & 2.43 & 3.38 & 14.63 & 5.4 & -.30 & -3.10 & -3.42 & 793 \\
\hline Savings and small time deposits & 2.95 & 7.29 & 8.71 & 10.51 & 6.24 & .18 & -.85 & -.05 & 8.35 & 8.33 & 1,593 \\
\hline Managed liabilities ${ }^{1}$ & 6.90 & 2.26 & 5.20 & -6.16 & -6.18 & -6.03 & 12.28 & 17.64 & 10.62 & 9.71 & 1,514 \\
\hline Deposits booked in foreign & & & & & & & & & & & \\
\hline 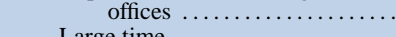 & 8.86 & -7.77 & -1.08 & -5.88 & 3.82 & -5.85 & 15.05 & 30.89 & 5.13 & 4.26 & 473 \\
\hline $\begin{array}{l}\text { Large time .............. } \\
\text { Subordinated notes and }\end{array}$ & 12.16 & 9.22 & 5.00 & -5.68 & -19.73 & -26.20 & -9.2 & 8.73 & 19.60 & 21.18 & 315 \\
\hline debentures & 3.72 & -4.26 & 16.98 & 20.99 & 4.69 & 34.89 & 10.82 & 9.24 & 6.61 & 17.77 & 51 \\
\hline Other managed liabilities & .78 & 5.45 & 10.12 & -8.11 & -1.34 & 7.11 & 22.18 & 13.02 & 11.66 & 8.32 & 674 \\
\hline Other . & 3.75 & .08 & 2.59 & 4.36 & -4.28 & -1.05 & 14.93 & 77.82 & 20.32 & 2.83 & 280 \\
\hline Equity capital & -.66 & 8.77 & 4.18 & 6.68 & 5.98 & 13.78 & 12.56 & 5.24 & 12.08 & 7.54 & 375 \\
\hline $\begin{array}{l}\text { MEмо } \\
\text { Commercial real estate loans }\end{array}$ & n.a. & n.a. & n.a. & n.a. & 10.68 & -5.18 & -1.33 & 3.74 & 5.82 & 7.78 & 414 \\
\hline $\begin{array}{l}\text { Note. Data are from year-end to } \\
\text { n.a. Not available. } \\
\text { 1. Measured as the sum of depos }\end{array}$ & & & & & $\begin{array}{l}\text { d loans } \\
\text { ivities }\end{array}$ & tecte & rear & al es & onstruc & and 1 & $\begin{array}{l}\text { loans securec } \\
\text { ial properties } \\
\text { i developmen }\end{array}$ \\
\hline
\end{tabular}

debentures, and other borrowed money. 
The securitized share of bank-originated consumer loans rose further last year, to almost 25 percent (chart 5). After adjustment for securitization, the slowing of growth of consumer loans on banks' balance sheets is much less pronounced-from a little more than 17 percent in 1995 to about $141 / 4$ percent in 1996.

LPS respondents indicated that the demand for consumer loans dropped off a bit at the end of the year (chart 6). The decline may have been a result of higher consumer debt burdens. On the supply side, banks reported that they had tightened standards for approving consumer loans, particularly credit card loans, as well as terms on new or existing credit card

3. Spread of C\&I loan rate over intended federal funds rate, by size of loan, 1987-96

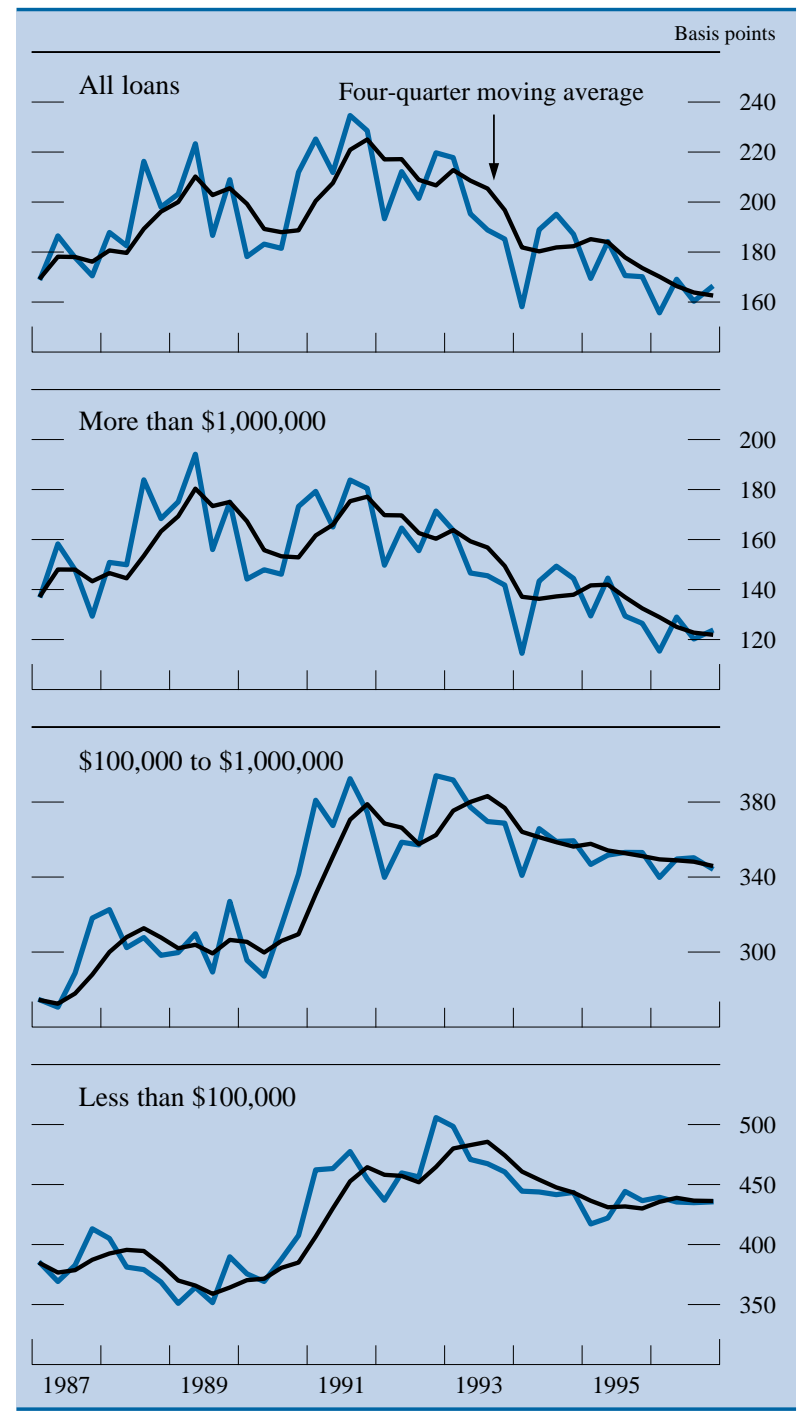

NoTE. The data are quarterly.

SourcE. Survey of Terms of Bank Lending to Business, Federal Reserve Board statistical release E.2.
4. Outstanding bank loans as a share of total credit market debt of nonfinancial businesses, 1970-96

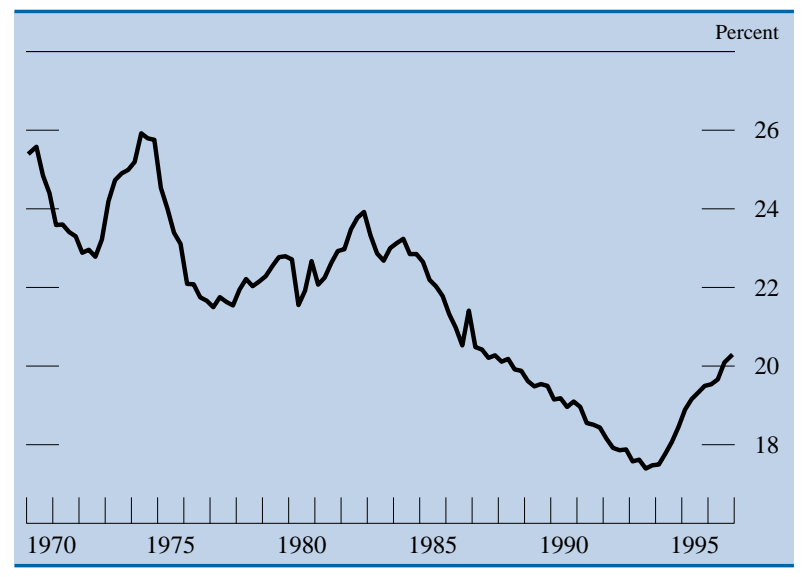

Note. The data are quarterly.

Source. Flow of funds accounts of the United States, table L. 101.

loans, most often by reducing credit lines or widening the spreads of loan rates over base rates. These reports of tightening are in sharp contrast to the picture at the beginning of 1995, when banks reported having eased standards for approving credit card applications as well as terms on credit card accounts, by narrowing spreads over base rates, raising credit limits, and reducing annual fees. Despite the reported tightening of standards in 1996, banks increased lines of credit on credit cards faster than outstandings increased, resulting in a slight drop in utilization rates.

Residential mortgages, which represent $14 \frac{1}{2}$ percent of commercial bank assets, also grew more slowly in 1996-about 5 percent, a little less than half the average for the past three years. Although the LPS indicated that banks had slightly tightened

5. Securitized share of consumer loan outstandings originated by banks, 1988-96

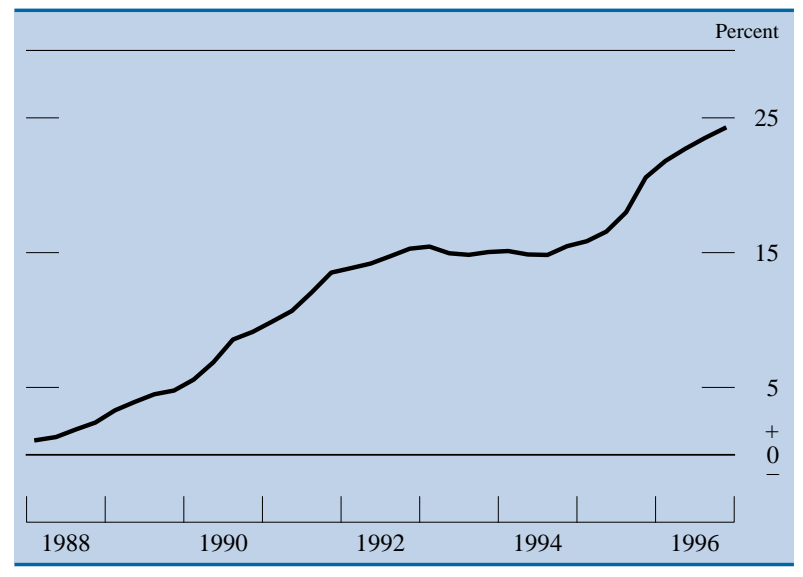

Note. The data are quarterly. 
6. Net percentage of selected commercial banks that experienced increased demand for consumer loans, 1992-96

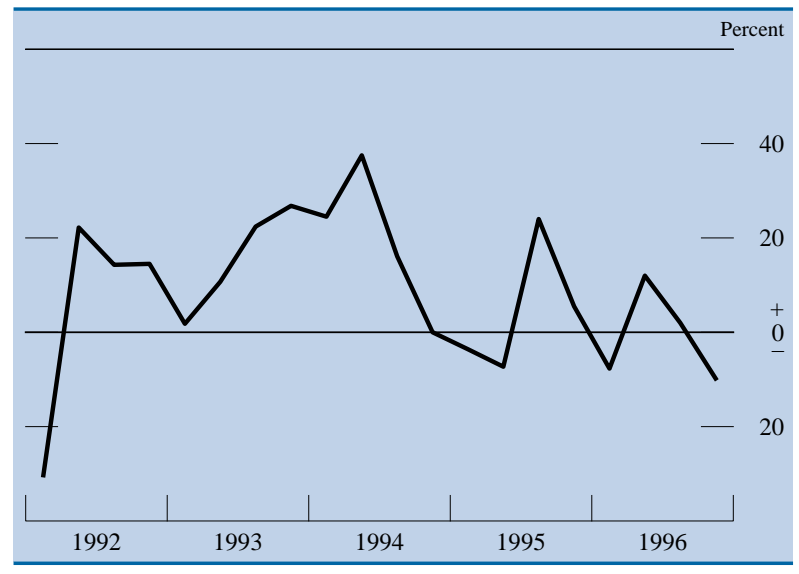

NoTE. The data are quarterly. Net percentage is the percentage of banks reporting increased demand less the percentage reporting decreased demand.

Source. Senior Loan Officer Opinion Survey on Bank Lending Practices.

lending standards for home mortgages, the slowing of growth appears to reflect a heavy pace of securitization rather than a reduced pace of originations: Total residential mortgages originated by banks and nonbanks, including mortgages held in pools of mortgage securities, expanded $81 / 4$ percent last year, the fastest rate since 1990 .

Loans in one residential real estate category, home equity loans, increased significantly over the year. Respondents to the LPS reported stronger demand for such loans. In addition, some banks increased their marketing efforts for home equity loans and targeted specific customers in an effort to encourage a shift from unsecured consumer loans to secured home equity lines. Because home equity lines are often used to pay down unsecured consumer debt, their expansion likely explains a portion of the slowing of growth of consumer lending.

\section{Securities}

Banks' securities holdings grew less than 1 percent in 1996 and at year-end represented 21 percent of assets, the lowest proportion in five years. Banks used a portion of their investment account securities as a source of funds, but this decline was about offset by an increase in the value of securities held in trading accounts. Small banks held a greater proportion of their assets in securities than did large banks, nearly 30 percent compared with 17 percent.

An off-balance-sheet item of note is banks' holdings of derivatives. During 1996, the notional value of derivatives contracts of all types held by banks increased about 181/4 percent over 1995's year-end value; a large part of the increase occurred at the ten largest banks, which hold the vast majority of such contracts. ${ }^{5}$ Most of the holdings were in the form of interest rate contracts. Of the year-end 1996 notional value, more than 92 percent was related to contracts held for trading purposes; these are used primarily to help customers hedge against the risk of changes in interest rates, exchange rates, equity prices, and commodity prices. The remainder was related to contracts held for nontrading purposes, primarily to hedge against risks to the banks themselves.

\section{Liabilities}

Core deposits at banks advanced moderately in 1996, growing more slowly than bank assets. Growth was sluggish partly because banks set deposit rates low relative to the rates of return available on alternative investments (chart 7). On average, rates on money market mutual funds were 2 percentage points higher than rates on bank savings accounts, and the return on most stock mutual funds also significantly exceeded bank deposit rates.

Within core deposits, transaction deposits fell for the third year in a row. The decline can be attributed to the implementation of retail "sweep" accounts, whereby funds are automatically swept out of trans-

5. The notional value of a derivative is the value of the underlying financial asset, index, or other investment used to calculate the payments specified in the contract. Only the payments represent benefits or risks to the banks.

\section{Selected interest rates, 1987-96}

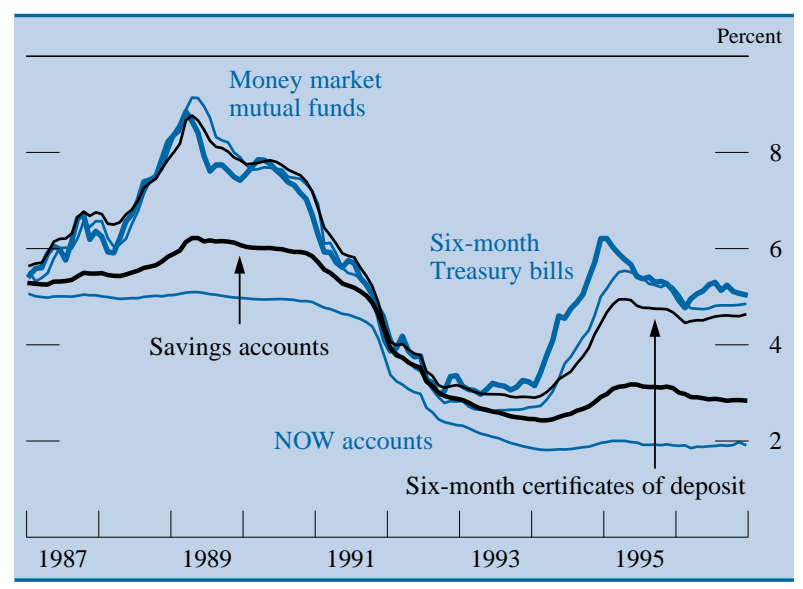

Note. The data are monthly. Rates are at commercial banks. Savings accounts include money market deposit accounts.

SourCES. Federal Reserve Board statistical releases H.6 and H.15. 
action accounts, against which banks must hold reserves, and into money market accounts, against which they need not hold reserves. This arrangement has no effect on the total amount of retail deposits, but it does reduce the amount of non-interest-bearing required reserves a bank must hold at the Federal Reserve, freeing up these funds to be invested elsewhere. In 1996 the volume of new retail sweep accounts tripled, bringing the cumulative amount swept out of retail transaction accounts to about $\$ 170$ billion (chart 8).

To fund the growth of bank assets in the presence of the relatively slow expansion of core deposits, banks relied heavily on managed liabilities, which grew faster than total bank assets for the fourth consecutive year. Increases in large time deposits and in subordinated notes and debentures fueled the growth in this category, while deposits booked in foreign offices were a much less important source of funds for domestic lending. The rates of growth for different categories of managed liabilities have varied widely over the past few years, in part because of the reduction of deposit insurance premiums in 1995 and the beginning of 1996, which increased the attractiveness of large time deposits as a source of funds. ${ }^{6}$

6. Over this period, deposit insurance premiums for wellcapitalized banks were reduced to zero. Although they are insured up to only $\$ 100,000$, large time deposits are included in the assessment base used to determine insurance premiums, and therefore the cost of this source of funding varies with the insurance premiums. Deposit insurance premiums are not paid on foreign deposits. For further discussion, see William R. Nelson and Brian K. Reid, "Profits and Balance Sheet Developments at U.S. Commercial Banks in 1995," Federal Reserve Bulletin, vol. 82 (June 1996), pp. 483-505.

8. Cumulative amount transferred out of retail transaction accounts upon initiation of sweep accounts, 1994-96

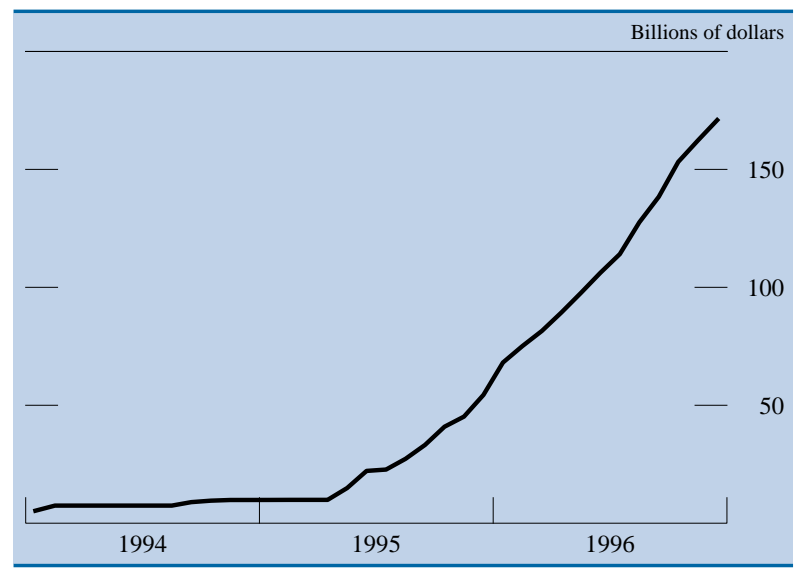

Note. The data are monthly.

\section{Capital}

The share of their assets that banks funded with capital was about the same in 1996 as it was in 1995. As a result, the leverage ratio remained basically unchanged last year, on net, although risk-based capital ratios (tier 1 and total) declined slightly (chart 9). ${ }^{7}$ The risk-based capital measures have fallen a bit over the past two years because of the relatively more rapid growth of loans, which carry

7. The tier 1 ratio is the ratio of tier 1 capital to risk-weighted assets, and the total ratio is the ratio of the sum of tier 1 and tier 2 capital to risk-weighted assets. Tier 1 capital consists mainly of common equity (excluding capital gains and losses on investment account securities classified as available for sale) and certain perpetual preferred stock. Tier 2 capital consists primarily of subordinated debt, non-tier 1 preferred stock, and loan-loss reserves. Risk-weighted assets are calculated by multiplying the amount of assets and the credit equivalent amount of off-balance-sheet items by the risk weight for each category. The leverage ratio is the ratio of tier 1 capital to total assets.

For a summary of the evolution of risk-based capital standards, see Allan D. Brunner and William B. English, "Profits and Balance Sheet Developments at U.S. Commercial Banks in 1992," Federal Reserve Bulletin, vol. 79 (July 1993), pp. 661-62.

9. Regulatory capital ratios, and share of industry assets at well-capitalized banks, 1991-96

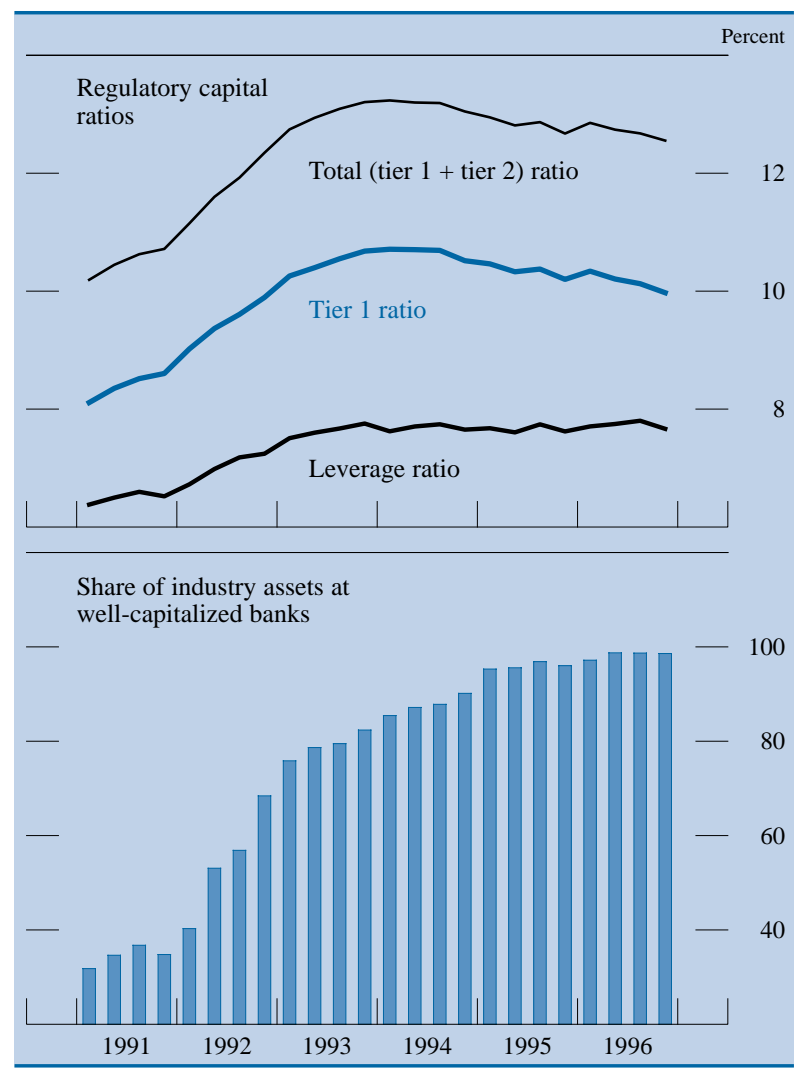

Note. The data are quarterly. For definitions of tier 1 and tier 2 capital and leverage ratio, see text footnote 7 . 
higher risk weights than do securities. ${ }^{8}$ Despite the decline in industry-average capital ratios, the fraction of bank assets at well-capitalized banks-those with sound capital ratios and positive examiner ratingsincreased again last year, crowding still closer to 100 percent.

Banks boosted their equity last year even though they significantly increased the share of income they paid out as dividends. This high payout by banks contributed to generous distributions by bank holding companies. The top fifty bank holding companies increased their dividends about 20 percent. Furthermore, net expenditures on stock repurchases by these companies grew more than 50 percent last year and approached four-fifths of the amount disbursed through dividends.

\section{TRENDS IN PROFITABILITY}

The net income of U.S. commercial banks grew 8 percent in 1996, the seventh consecutive annual increase. The return on equity remained in the elevated range it has occupied since 1993, and the return on assets posted a new high. The increase in profitability was widespread: The average return on assets rose for all four bank size groups, and net income was positive at 95 percent of all banks, accounting for 99 percent of total bank assets. Profits were boosted a bit by growth of net interest income but more by higher noninterest income. Taken together, the gains in net interest and noninterest income exceeded the increases in noninterest expense and provisioning for loan and lease losses. Propelled in part by growth of profits, stocks of large bank holding companies outperformed the broader market in 1996, as they had in 1995 (chart 10).

Last year was the fourth consecutive year in which measures of commercial bank profitability significantly exceeded the long-term norms. For example,

8. Banks' capital situation was not materially affected by holding companies' explosive issuance of trust preferred securities last fall. These securities are created when a bank holding company establishes a trust that issues cumulative preferred stock and then loans the proceeds to the parent company. The resulting liability counts as tier 1 capital for the holding company, but the interest payments on the debt are tax deductible- a combination of features sufficiently attractive that holding companies issued $\$ 6$ billion of these securities last year in the public market and probably several times that amount in the private market. Nevertheless, these transactions do not show up on banks' balance sheets except in the rare instance that the trust issuing the securities is organized under the bank rather than the holding company, in which case the preferred stock is classified as tier 2 capital for the bank. In 1996 banks issued about $\$ 1.2$ billion in trust preferred securities, only $1 / 3$ of 1 percent of total (tier 1 plus tier 2) bank capital.
10. Stock price indexes, 1996-April 1997

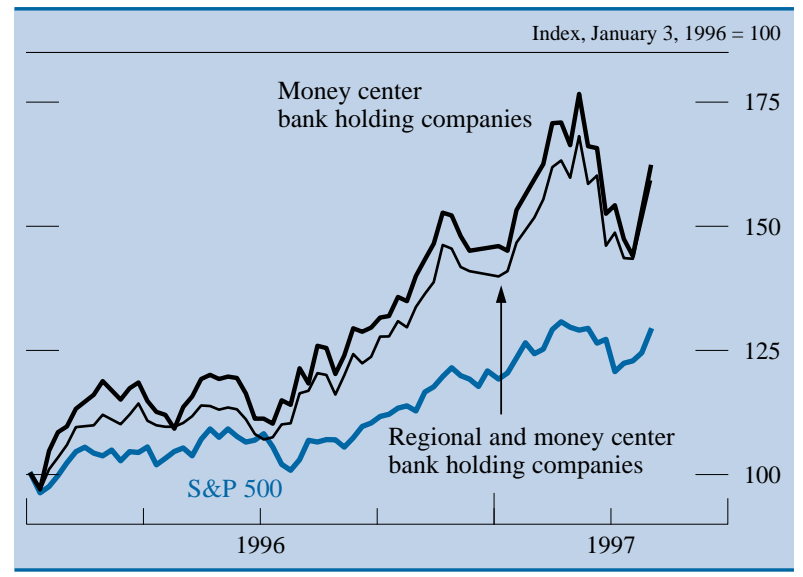

Note. The data are weekly. The bank indexes are for eight money center bank holding companies and forty-two regional bank holding companies as defined by Salomon Brothers.

SourCES. Salomon Brothers and Standard \& Poor's.

the return on assets averaged 63 basis points more over the past four years than over the preceding seven years (table 1). The recent improvement is due in part to a sharp drop in loss provisioning relative to assets, which has allowed some other longer-term trends boosting return on assets to show through. First, the ratio of net interest income to assets has been increasing because banks have been shifting their portfolios toward riskier assets, which carry higher yields, and have been funding a larger share of assets with capital instead of interest-bearing liabilities. Also, ongoing improvements in efficiency have helped banks lower the ratio of noninterest expense to revenue. Finally, noninterest income has accounted for a steadily growing share of revenue, partly because of the increasing importance of off-balance-sheet activity. ${ }^{9}$

\section{Interest Income and Expense}

Both interest income and interest expense as a percentage of assets fell slightly at commercial banks

9. The increasing importance of off-balance-sheet activity has also made return on assets as a measure of profitability less meaningful over time. Nevertheless, a large fraction of banking is still tied to traditional on-balance-sheet items, and in interpreting changes in net income, assets remain a useful scaling factor for separating the effects of growth from those of improved profitability. The other common measure of profitability-return on equity-is, of course, not affected by changes in the relative importance of off-balance-sheet activity. However, interpreting trends in this measure is complicated by the significant increases in capital-to-assets ratios in recent years in response, in part, to regulatory changes. 
last year, reflecting the moderately lower market rates that prevailed, on average, in 1996 relative to 1995. The decline in expense exceeded the decline in income, leaving net interest income as a percentage of assets (the net interest margin) 3 basis points higher than in 1995 and, despite declines in 1994 and 1995, still elevated relative to the late 1980s.

The net interest margin was held down in the late 1980s by competition among banks for loans and funding sources. It surged in 1991 and 1992 as banks widened spreads between loan and deposit rates in an effort to improve capital ratios by boosting earnings and curbing asset growth (chart 11). The rise occurred even though loans, which tend to yield more than securities, declined as a share of assets.

Since 1992, more aggressive loan pricing and greater reliance on managed liabilities have squeezed the net interest margin somewhat, but it remains high for several reasons. First, compared with the early 1990s, banks fund a significantly larger fraction of assets with capital, and the returns on capital are not considered an interest expense. Also, rates paid on retail deposits have been low relative to market rates. Finally, the margin has been held up significantly by

11. Net interest income and the composition of assets, 1985-96

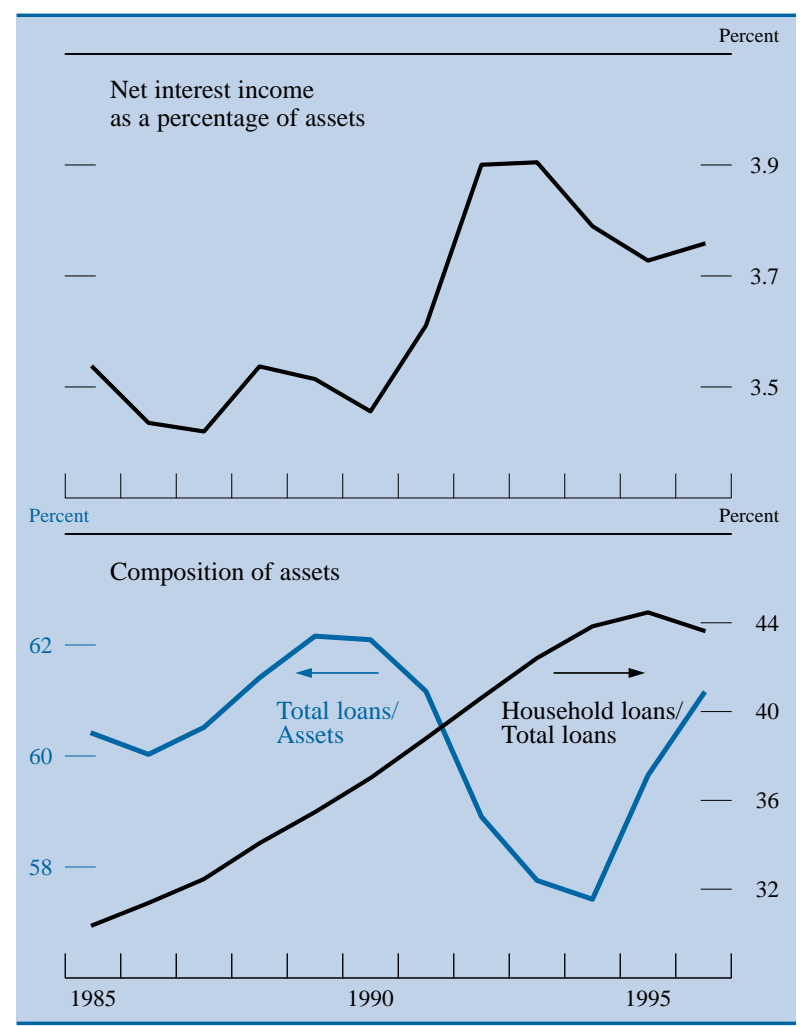

Note. The data are annual. a rebound in the share of assets in loans and a rising volume of loans to households, a relatively high yielding category of loans.

\section{Noninterest Income and Expense}

Noninterest income provided a hefty boost to return on assets last year, increasing 17 basis points as a percentage of assets relative to 1995 . Over the past ten years, noninterest income has accounted for an expanding share of bank revenue (chart 12). A small part of the increase has been from fiduciary activities and trading revenue, but most of the growth has been in the broad category "other noninterest income," which includes merchant credit card fees, annual cardholder fees, fees for servicing mortgages, and income from loans that have been securitized. Thus, the increase in the proportion of revenue accounted for by noninterest income likely reflects both the expansion of bank lending to households and the growing fraction of bank loans that are securitized.

12. Noninterest income and its components as a percentage of total revenue, 1985-96

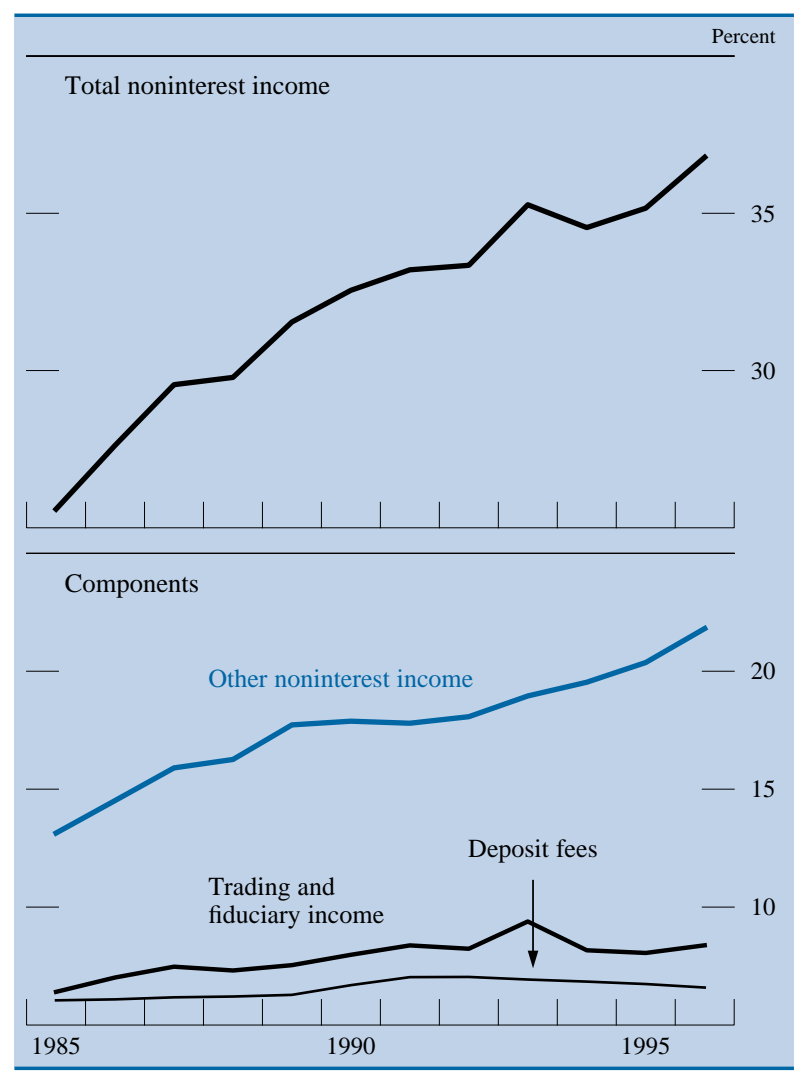

Note. The data are annual. 
Noninterest expense as a percentage of assets rose 8 basis points in 1996 even though occupancy and employee costs were about unchanged. The increase reflects a rise in "other noninterest expense" accounted for by two recent adjustments in deposit insurance premiums. In 1995, banks received a rebate of $\$ 1 \frac{1}{2}$ billion for overpayment of deposit insurance, while in 1996, banks that had acquired thrift deposits paid a $\$ 1 \frac{1 / 4}{4}$ billion one-time assessment to support the Savings Association Insurance Fund. Other noninterest expense was also boosted last year by higher merger restructuring charges, with the Chase Manhattan Corporation-Chemical Banking Corporation merger alone accounting for $\$ 13 / 4$ billion in expenses. (See the accompanying box for a brief discussion of the continuing consolidation of the banking industry.)

Over the past ten years, noninterest expense has been held in check in part by a decline in employment and occupancy costs as a percentage of revenue

\section{Consolidation of the Banking Industry}

The past decade has seen a marked consolidation of the U.S. commercial banking industry. In 1996, 359 banking organizations with combined assets totaling about $\$ 450$ billion merged or were acquired, contributing to the continuing decline in the number of banks and bank holding companies (chart). As a result of this consolidation, the assets held by the fifty largest bank holding companies represent an increasing share of total banking assets (chart).

Regulatory changes have been an important factor in the consolidation of the banking industry. For many years, legal restrictions on the geographic expansion of banks generally limited the size of any one bank or bank holding company; in many cases a banking organization was prohibited from expanding within its home state as well as into other states. Over the past fifteen years, these restrictions have been eased. Most states now allow some, if not all, out-of-state bank holding companies to own banks within their state. Many states have also lifted restrictions on intrastate branching of state-chartered banks, which in turn has resulted in broader branching powers being given to national banks.

The Riegle-Neal Interstate Banking and Branching Efficiency Act of 1994 went even further in removing geographic restrictions by allowing bank holding companies to

\section{Number of U.S. commercial banking organizations, 1986-96}

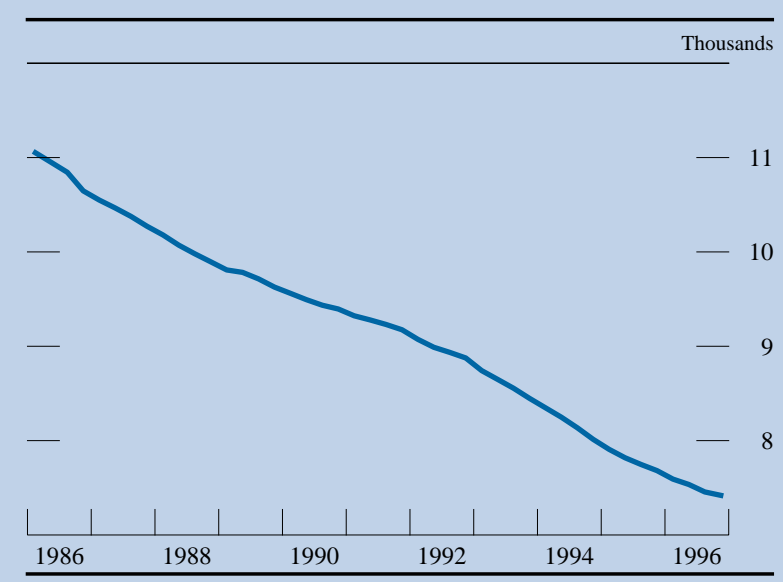

purchase banks throughout the United States after September 1995. In June 1997, remaining legal restrictions on geographic expansion were removed, and all banks are now allowed to acquire established branches through interstate mergers, provided that the state has not opted out of interstate banking. ${ }^{1}$ (Only Texas and Montana have opted out.)

Before completing a merger or acquisition, banks and bank holding companies still must obtain approval from the appropriate regulatory agencies. Under the Bank Holding Company Act and the Bank Merger Act, the Board of Governors of the Federal Reserve System oversees the mergers and acquisitions of bank holding companies and of state member banks. In considering these applications, the Board looks at the effect of the merger or acquisition on the competitiveness of the relevant banking market, the financial and managerial resources of the firms involved, and the convenience and needs of the community.

1. Both the purchase of banks by out-of-state holding companies and the acquisition of established branches through interstate mergers are subject to deposit caps and certain state laws. Specifically, the combined organization may control no more than 10 percent of the insured deposits in the United States and is subject to deposit limits of the relevant state. In addition, the acquired bank must have been in existence the minimum amount of time required by state law.

Share of banking assets held by the fifty largest bank holding companies, 1986-96

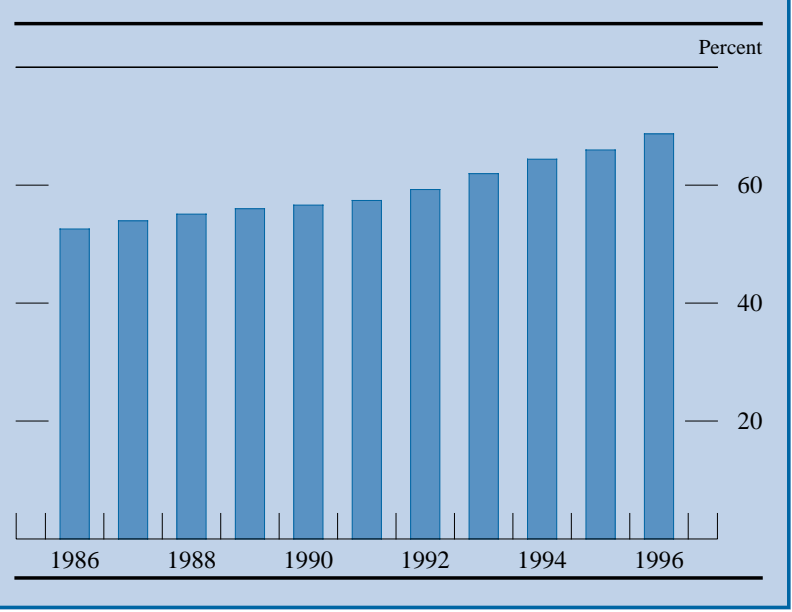


13. Noninterest expense and its components as a percentage of total revenue, 1985-96

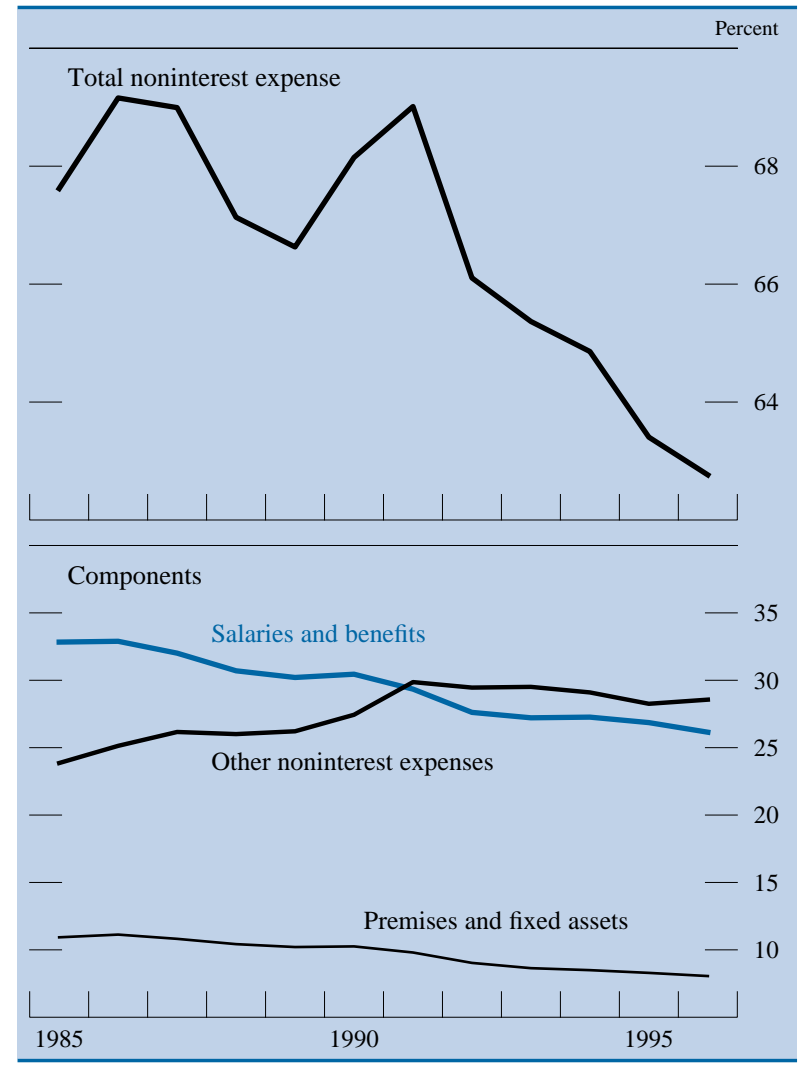

Note. The data are annual.

(chart 13). Employment levels in the industry fell during the late 1980s and early 1990s and have since remained about unchanged. Occupancy costs have likely benefited from the slow growth of the number of bank offices, which rose only 17 percent between 1986 and 1996, one-third the increase in revenue, adjusted for inflation, over that period. Furthermore, over the ten years, the inflation-adjusted cost per office fell more than 10 percent. These costs may have been contained in part by the growing popularity of low-cost supermarket branches. By contrast, other noninterest expense, a broad category that accounts for nearly half of noninterest expense and includes deposit insurance premiums, losses on the sale of various assets, amortization of intangible assets, expenditures for information processing services provided by others, and merger restructuring charges, has risen a bit relative to revenue. Nevertheless, the ratio of total noninterest expense to revenue has fallen over the past ten years; thus, at least by this common measure of efficiency, banks appear to have significantly streamlined their operations.

\section{Loss Provisioning and Loan Quality}

Since 1992, the banking industry has been setting aside as a provision against losses on loans and leases amounts very close to their net charge-offs (chart 14). In keeping with this pattern, provisioning rose slightly last year, matching a small increase in net charge-offs. Although loan-loss provisioning relative to assets edged higher over the past two years, it was quite a bit lower at the end of 1996 than earlier in the 1990s and about the same as at the beginning of the 1980s. Banks were able to reduce provisioning in 1992 because improvements in loan quality and a contraction in loans sharply reduced their need for loan-loss reserves. In recent years, continued improvements in measured loan quality have allowed banks to equalize provisioning and net charge-offs, leaving the level of reserves unchanged. Although the ratio of reserves to loans fell in each of the past four years, the ratio of reserves to delinquent loans increased until 1995, fell only slightly last year, and was more than 80 percent at year-end (chart 15). However, net charge-offs grew faster than delinquencies, and the ratio of reserves to charge-offs fell fairly sharply in the past two years. Still, in 1996, loan-loss reserves were $3 \frac{1}{2}$ times as large as net charge-offs in that year, a bit above average.

Although the decline in provisioning relative to the levels in the troubled late 1980s and early 1990s has helped boost measures of bank profitability, banks would still be solidly profitable even if provisioning were much higher. For example, if provisioning had been double its actual level last year, the ratio of provisioning to assets would have been about 50 percent higher than its average level since 1970. Nevertheless, net interest income less provisioning

14. Reserves for loan and lease losses, loss provisioning, and net charge-offs as a percentage of loans, 1980-96

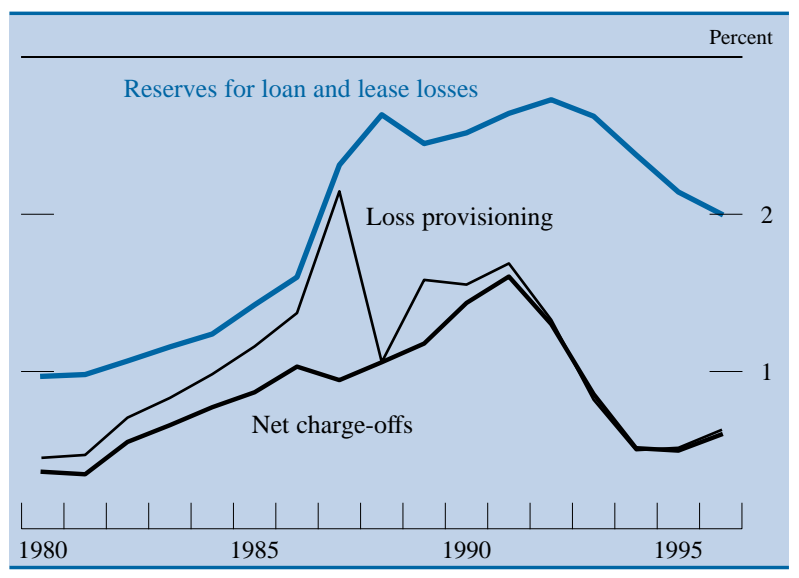

Note. The data are annual. 
15. Measures of the adequacy of loan-loss reserves, 1985-96

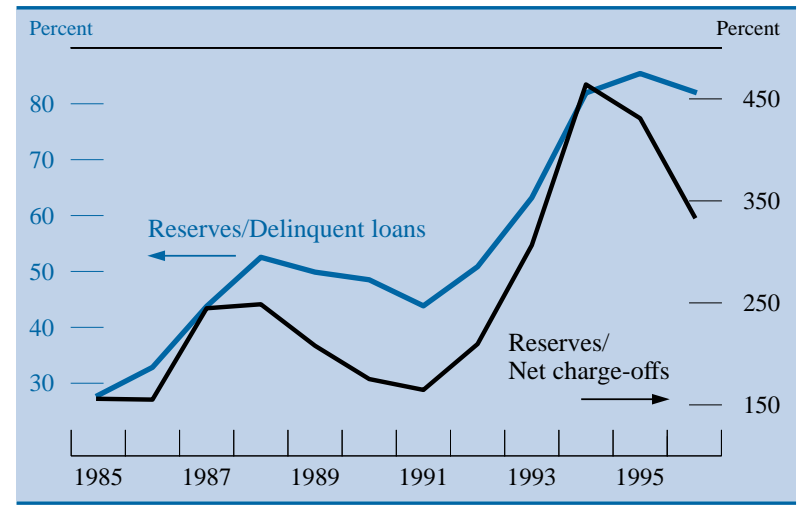

Note. The data are annual.

would have equaled 3 percent of assets, slightly above the average level for this ratio since 1970. The return on assets would drop to a bit under 1 percent, but it would still be a bit above its average over the period, and the return on equity would fall to $11 \frac{1}{2}$ percent, about equal to its average over the period.

Banks were able to keep provisioning low last year because, overall, the performance of bank loans remained quite good. Delinquency and charge-off
16. Delinquency and charge-off rates, all loans, 1985-96

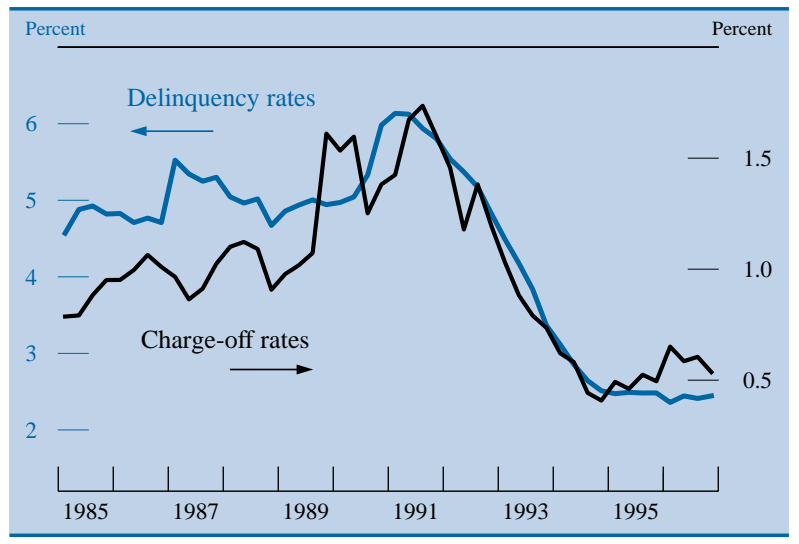

NoTE. The data are quarterly and are seasonally adjusted. Delinquent loans are loans that are not accruing interest and those that are accuring interest but are more than thirty days past due. The delinquency rate is the end-of-period level of delinquent loans divided by the end-of-period level of outstanding loans. The charge-off rate is the annualized amount of charge-offs over the quarter net of recoveries, divided by the average level of outstanding loans.

rates for loans to businesses remained low even as the performance of loans to households deteriorated further (chart 16). Within the business loan category, the performance of commercial real estate loans has been improving dramatically (chart 17). Indeed, the net

\section{Delinquency and charge-off rates, by type of loan, 1991-96}

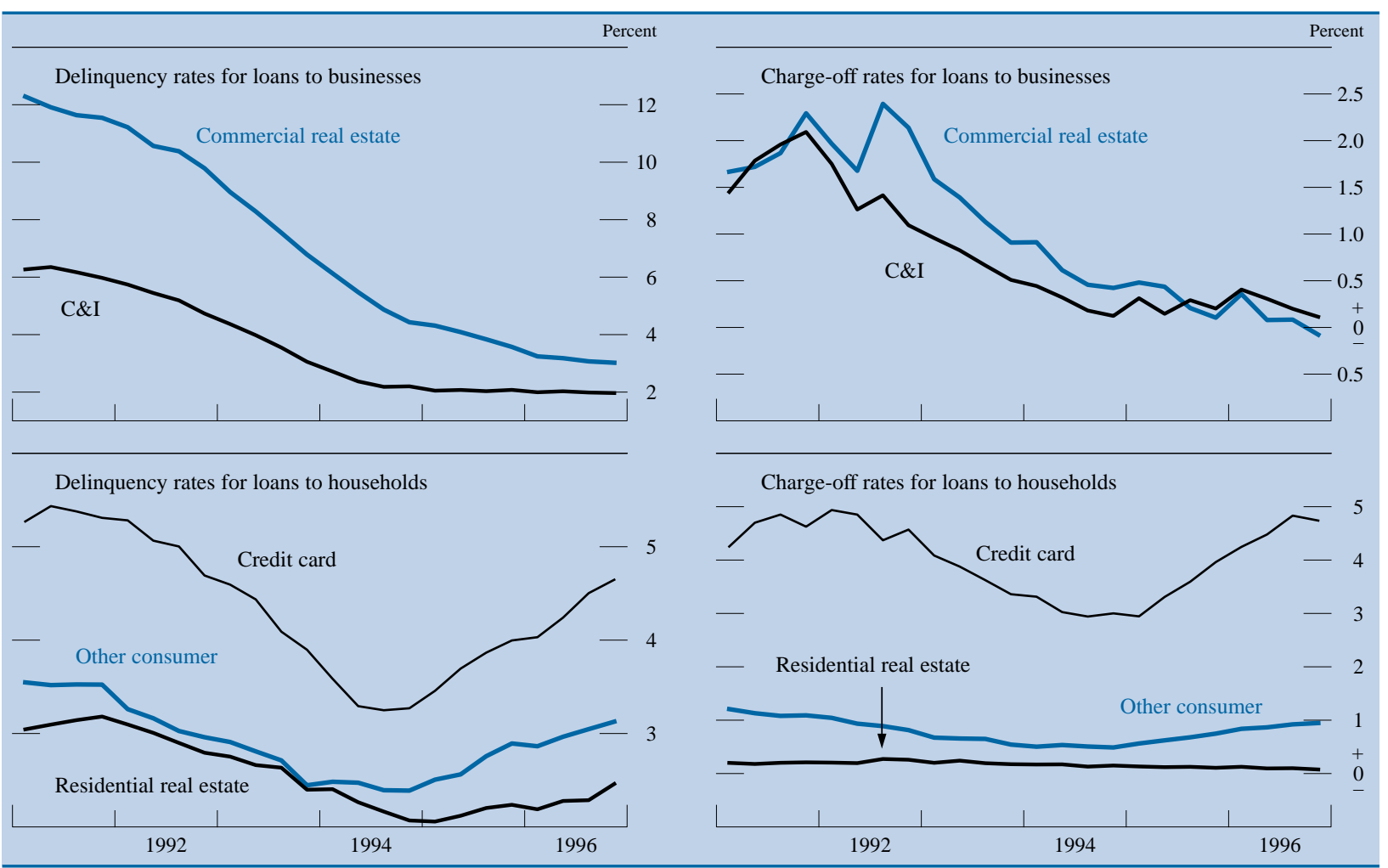

Note. The data are quarterly and are seasonally adjusted. See note on chart 16. 


\section{Credit Card Banks}

Since the early 1980s, bank holding companies have been creating subsidiary banks that specialize in credit card lending. These institutions were initially established in states that had a high interest rate ceiling, or no ceiling at all, to avoid the limitations imposed by usury laws in other states. Although interest rate ceilings no longer restrict desired lending rates in most states, bank holding companies continue to create subsidiaries that specialize in credit card lending, presumably because of the economies of scale that are obtained by concentrating this line of business at a single bank. In 1996, credit card banks, defined here as banks among the top 1,000 by assets for which credit card loans constitute more than half of assets, accounted for more than 60 percent of credit card outstandings at all banks. By this definition, there were forty credit card banks at the end of 1996, up from eleven at the end of 1985.

On average, 85 percent of the assets of these banks at the end of 1996 were credit card receivables (table). The banks funded themselves largely with managed liabilities, and they had significantly higher capital ratios than the typical commercial bank. Credit card banks also fund a relatively large fraction of the loans they originate through securitizations, which typically remove the affected loans from their books. At year-end 1996, about one-half of the outstanding balances on credit card loans made by these banks were securitized, compared with about one-fourth for the rest of the industry.

The profitability of credit card banks has been reduced by the erosion of consumer credit quality. Delinquency and charge-off rates for loans at credit card banks have risen sharply in the past two years, and returns on assets and on equity at these banks have fallen dramatically. Nearly onefourth of credit card banks, accounting for about 10 percent of the assets held by such banks, posted losses in 1996 . Still, the average return on equity at credit card banks last year was well above the average for commercial banks as a whole (chart).

Rising loan-loss rates lower the profits of credit card banks in two ways. For loans on their balance sheets, charge-offs deplete loan-loss reserves and lead to higher provisioning. Indeed, provisioning as a percentage of assets at these banks increased more than 1 percentage point in the past two years. Higher charge-off rates need not imply reduced profitability if interest margins are rising to offset the losses. However, intense competition for credit card balances has placed downward pressure on net interest margins even as losses have mounted. In sum, net interest income less provisioning fell from 5 percent of assets in 1993 to 3 percent last year.

Selected balance sheet items for credit card banks and all banks, 1996

Percentage of assets

\begin{tabular}{|c|c|c|}
\hline Item & $\begin{array}{l}\text { Credit card } \\
\text { banks }\end{array}$ & All banks \\
\hline $\begin{array}{l}\text { Loans } \ldots \ldots \ldots . . . \\
\quad \text { Consumer } \ldots . . \\
\text { Credit card } \ldots \\
\text { Securities } \ldots . . .\end{array}$ & $\begin{array}{r}87.64 \\
85.01 \\
83.98 \\
3.98\end{array}$ & $\begin{array}{r}61.12 \\
12.26 \\
4.93 \\
18.20\end{array}$ \\
\hline Managed liabilities & 79.15 & 32.73 \\
\hline Capital account & 11.54 & 8.27 \\
\hline
\end{tabular}

charge-off rate for these loans hovered near zero over most of last year, as banks recovered amounts similar to the amounts they charged off. Both delinquency and charge-off rates for C\&I loans remained near record lows in both 1995 and 1996.

By contrast, delinquency rates for loans to households have risen somewhat since 1994: Delinquency rates for credit card loans and for "other consumer loans" have reversed more than half of their declines from 1991 peaks, and the rate for residential real estate loans has reversed about one-third of its decline. Charge-off rates for credit card loans and other consumer loans also are higher, with the loss rate for credit card loans in 1996 nearly reaching the peak levels of the early 1990s. Banks that specialize in credit card lending have been particularly hurt by the rising loss rates (see box "Credit Card Banks").

Some of the disparity in the performances of household and businesses loans can be accounted for by differences in financial stress experienced by the two sectors (chart 18). For businesses, the ratio of interest payments to revenue has been relatively low in recent years, whereas for households, the ratio of interest payments and required principal payments to disposable income has risen steadily to about its elevated level at the end of the 1980s. In recent years banks have been aggressively marketing consumer credit to more-marginal borrowers. This expansion of credit to households that would not have qualified previously is probably one of the reasons household debt burden has gone up and also suggests that banks may have anticipated some of the rise in the chargeoff rates on these loans.

Another factor influencing delinquency and charge-off rates may have been changes in the pace of loan growth. An increase in the rate of growth of a loan portfolio generally lowers its average age. Because loans are less likely to go bad soon after they are made, a reduction in average age may tem- 


\section{Credit Card Banks-Continued}

\section{Measures of profitability and components of revenue at credit card banks, 1985-96}

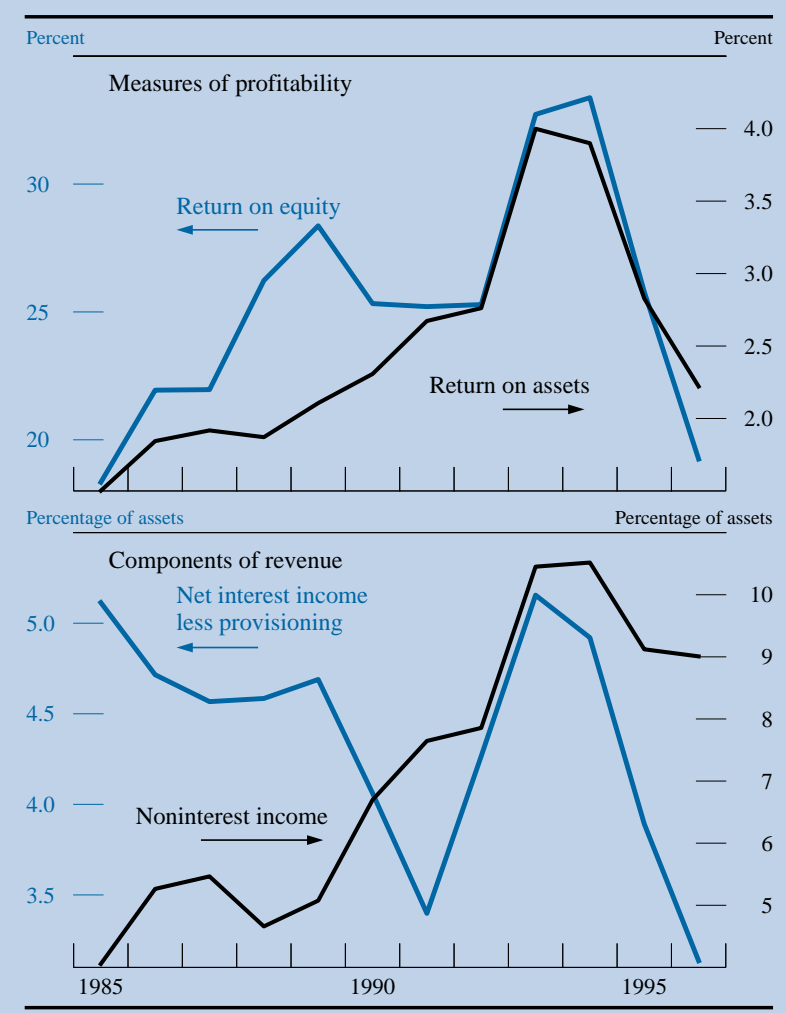

For loans that have been removed from banks' balance sheets through securitization, charge-offs result in lower fee income. The residual between the rates paid on securities backed by credit card loans and the rates earned on the underlying loans accrues to the bank as fee income, but only after loan losses have been covered. ${ }^{1}$ Noninterest income, which includes fee income, has fallen $1 \frac{1}{2}$ percentage points as a share of assets since 1993. If the net charge-off rate for securitized loans were the same as the rate reported for on-balance-sheet loans, nearly all the decline in noninterest income could be accounted for by the increased losses.

Even as loan quality at credit card banks has deteriorated, increased provisioning has pushed up the level of loan-loss reserves relative to delinquent loans. Net charge-off rates have risen more quickly than delinquency rates, however, and the ratio of reserves to charge-offs has fallen over the past two years. At the end of last year, reserves equaled about nine months of losses, down from more than one year of losses at the end of 1994. Even if loss rates worsen, profit margins at these banks are, on average, wide enough to absorb additional increases in provisioning. Furthermore, the capital ratios at credit card banks, although having fallen slightly over the past few years, remain high.

1. For more information on the securitization of consumer loans by banks, see Nelson and Reid, "Profits and Balance Sheet Developments at U.S. Commercial Banks in 1995," p. 488. porarily lower delinquency and charge-off rates. As the loans in the portfolio mature, or "season," delinquency and charge-off rates tend to rise. The rapid growth of C\&I loans in recent years may thus be depressing their delinquency and charge-off rates.

\section{DEVELOPMENTS IN 1997}

During the first quarter of 1997, bank asset growth at domestic offices continued at the robust pace posted in the preceding quarter. The value of $C \& I$ loans increased sharply, and the value of real estate loans, which had grown only slowly in 1996, expanded solidly. By contrast, the value of consumer loans on banks' books was little changed over the quarter as moderate increases in outstanding amounts on loans originated by banks were about matched by securitizations.

\section{Business and household debt burden, 1985-96}

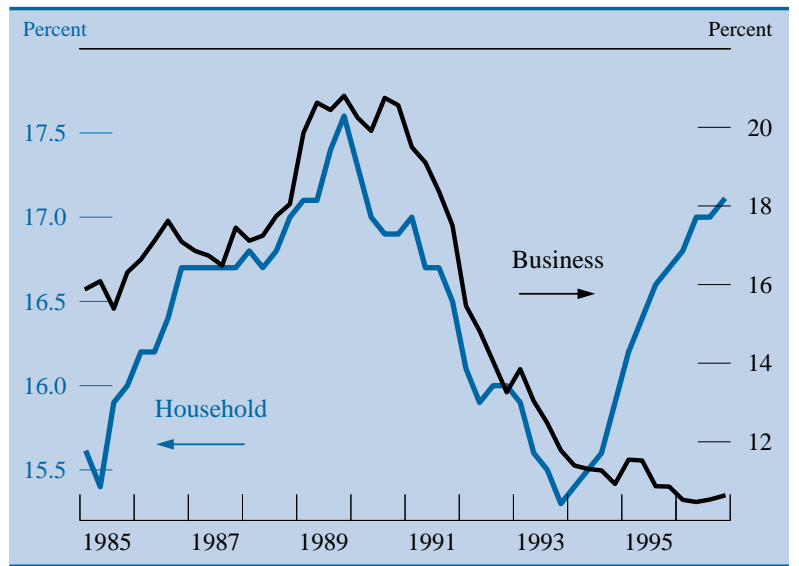

Note. The data are quarterly and are seasonally adjusted.

For businesses (nonfinancial corporations only), the debt burden is calculated as interest payments as a percentage of revenue; for households, it is an estimate of interest payments and required principal payments as a percentage of disposable income.

SoURCES. National income and product accounts and the Federal Reserve System. 
Despite some volatility perhaps resulting from fears of rising interest rates, indexes of stock prices of bank holding companies climbed further in 1997, rising 10 percent by the end of April and outpacing broader market indexes. Initial reports of bank hold- ing company profits showed solid gains in net interest and noninterest income and reductions in mergerrelated costs. Nevertheless, the earnings of several bank holding companies were again hurt by rising charge-offs of consumer loans. 
A.1. Report of income, all insured domestic commercial banks, 1987-96 Millions of dollars

\begin{tabular}{|c|c|c|c|c|c|c|c|c|c|c|}
\hline Item & 1987 & 1988 & 1989 & 1990 & 1991 & 1992 & 1993 & 1994 & 1995 & 1996 \\
\hline Gross interest income & 245,089 & 274,144 & 317,072 & 320,186 & 289,884 & 257,038 & 244,934 & 257,365 & 302,791 & 315,552 \\
\hline Taxable equivalent & 251,085 & 279,714 & 321,277 & 323,827 & 293,072 & 260,020 & 247,816 & 260,127 & 305,431 & 318,021 \\
\hline Loans $\ldots \ldots \ldots \ldots \ldots$ & 180,648 & 202,853 & 237,824 & 238,680 & 214,396 & 186,312 & 178,555 & 189,983 & 227,542 & 241,445 \\
\hline Securities ...... & 39,485 & 42,199 & 46,724 & 50,987 & 52,618 & 52,052 & 48,732 & 48,374 & 51,116 & 50,853 \\
\hline $\begin{array}{l}\text { Gross federal funds sold and reverse } \\
\text { repurchase agreements } \ldots \ldots \ldots \ldots\end{array}$ & 9,033 & 10,639 & 13,061 & 12,547 & 9,128 & 5,926 & 4,798 & 6,422 & 9,752 & 9,293 \\
\hline Other $\ldots \ldots \ldots \ldots \ldots \ldots$ & 15,923 & 18,453 & 19,463 & 17,970 & 13,745 & 12,748 & 12,848 & 12,588 & 14,383 & 13,962 \\
\hline Gross interest expense & 145,166 & 166,345 & 205,092 & 204,822 & 167,870 & 122,789 & 105,697 & 110,956 & 148,115 & 151,005 \\
\hline Deposits ............. & 115,807 & 130,310 & 157,481 & 161,365 & 138,930 & 99,038 & 79,575 & 79,205 & 105,427 & 107,951 \\
\hline $\begin{array}{l}\text { Gross federal funds purchased and } \\
\text { repurchase agreements } \ldots \ldots \ldots\end{array}$ & 15,926 & 18,963 & 24,898 & 22,769 & 14,359 & 9,279 & 8,449 & 12,481 & 18,424 & 16,902 \\
\hline Other $\ldots \ldots \ldots \ldots \ldots \ldots \ldots \ldots \ldots$ & 13,432 & 17,073 & 22,712 & 20,686 & 14,581 & 14,471 & 17,674 & 19,269 & 24,263 & 26,152 \\
\hline Net interest income & 99,923 & 107,799 & 111,980 & 115,364 & 122,014 & 134,249 & 139,237 & 146,409 & 154,676 & 164,547 \\
\hline Taxable equivalent & 105,919 & 113,369 & 116,185 & 119,005 & 125,202 & 137,231 & 142,119 & 149,171 & 157,316 & 167,016 \\
\hline Loss provisioning ${ }^{1}$ & 37,891 & 19,777 & 31,300 & 32,275 & 34,869 & 26,866 & 16,854 & 11,003 & 12,626 & 16,627 \\
\hline Noninterest income & 41,913 & 45,720 & 51,598 & 55,675 & 60,650 & 67,163 & 75,871 & 77,271 & 83,887 & 95,733 \\
\hline Service charges on deposits & 8,758 & 9,532 & 10,272 & 11,444 & 12,843 & 14,178 & 14,906 & 15,303 & 16,075 & 17,152 \\
\hline Income from fiduciary activities & 7,145 & 7,526 & 8,314 & 8,881 & 9,456 & 10,472 & 11,203 & 12,127 & 12,889 & 14,230 \\
\hline Trading income $\ldots . . . \ldots$ & 3,559 & 3,691 & 4,051 & 4,854 & 5,960 & 6,274 & 9,238 & 6,249 & 6,337 & 7,540 \\
\hline Other & 22,451 & 24,970 & 28,961 & 30,495 & 32,389 & 36,237 & 40,524 & 43,592 & 48,586 & 56,812 \\
\hline Noninterest expense & 97,857 & 103,062 & 108,993 & 116,559 & 126,061 & 133,143 & 140,608 & 145,074 & 151,260 & 163,364 \\
\hline Salaries, wages, and employee benefits & 45,405 & 47,134 & 49,413 & 52,082 & 53,602 & 55,625 & 58,542 & 60,988 & 64,076 & 68,055 \\
\hline Expenses of premises and fixed assets & 15,342 & 16,002 & 16,698 & 17,541 & 17,906 & 18,190 & 18,587 & 18,999 & 19,778 & 20,967 \\
\hline Other $\ldots \ldots \ldots \ldots \ldots \ldots \ldots \ldots \ldots \ldots \ldots \ldots$ & 37,110 & 39,926 & 42,882 & 46,934 & 54,553 & 59,329 & 63,479 & 65,087 & 67,407 & 74,342 \\
\hline Net noninterest expense & 55,944 & 57,342 & 57,395 & 60,884 & 65,411 & 65,980 & 64,737 & 67,803 & 67,373 & 67,631 \\
\hline $\begin{array}{r}\text { Realized gains on investment account } \\
\text { securities } \ldots \ldots \ldots \ldots \ldots \ldots \ldots\end{array}$ & 1,447 & 278 & 799 & 474 & 2,925 & 3,956 & 3,055 & -573 & 480 & 1,125 \\
\hline $\begin{array}{c}\text { Income before taxes and extraordinary } \\
\text { items } \ldots \ldots \ldots \ldots \ldots \ldots \ldots \ldots \ldots\end{array}$ & 7,536 & 30,956 & 24,083 & 22,680 & 24.659 & 45,358 & 60,703 & 67,034 & 75.157 & 81413 \\
\hline 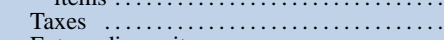 & 5,410 & 9,996 & 9,551 & 7,740 & 8,284 & 14,476 & 19,852 & 22,450 & 26,287 & 28,645 \\
\hline Extraordinary items & 200 & 811 & 313 & 649 & 993 & 404 & 2,087 & -17 & 28 & 91 \\
\hline Net income & 2,327 & 21,771 & 14,846 & 15,589 & 17,371 & 31,285 & 42,937 & 44,566 & 48,899 & $\mathbf{5 2 , 8 5 8}$ \\
\hline Cash dividends declared & 10,659 & 13,275 & 14,129 & 13,944 & 15,080 & 14,235 & 22,072 & 28,181 & 31,119 & 40,022 \\
\hline Retained income ....... & $-8,332$ & 8,496 & 716 & 1,645 & 2,291 & 17,050 & 20,865 & 16,385 & 17,779 & 12,836 \\
\hline
\end{tabular}

1. Includes provisioning for allocated transfer risk. 
A.2. Portfolio composition, interest rates, and income and expense, all insured domestic commercial banks, 1987-96 A. All banks

\begin{tabular}{|c|c|c|c|c|c|c|c|c|c|c|}
\hline Item & 1987 & 1988 & 1989 & 1990 & 1991 & 1992 & 1993 & 1994 & 1995 & 1996 \\
\hline & \multicolumn{10}{|c|}{ Balance sheet items as a percentage of average net consolidated assets } \\
\hline Interest-earning assets & 87.48 & 88.00 & 87.94 & 87.82 & 88.04 & 88.33 & 88.50 & 86.55 & 86.48 & 86.81 \\
\hline Loans and leases, net & 59.12 & 59.80 & 60.64 & 60.53 & 59.55 & 57.30 & 56.25 & 56.06 & 58.39 & 59.91 \\
\hline Commercial and industrial & 19.98 & 19.50 & 19.09 & 18.50 & 17.33 & 15.78 & 14.88 & 14.51 & 15.20 & 15.59 \\
\hline U.S. addressees .......... & 16.57 & 16.55 & 16.54 & 15.99 & 15.00 & 13.54 & 12.72 & 12.35 & 12.87 & 13.06 \\
\hline Foreign addressees ..... & 3.41 & 2.95 & 2.55 & 2.51 & 2.33 & 2.24 & 2.16 & 2.16 & 2.33 & 2.53 \\
\hline Consumer ........... & 11.42 & 11.72 & 11.89 & 11.77 & 11.45 & 11.02 & 11.00 & 11.43 & 12.11 & 12.26 \\
\hline Credit card & 3.17 & 3.47 & 3.69 & 3.78 & 3.88 & 3.82 & 3.89 & 4.21 & $\begin{array}{r}12.11 \\
4.72\end{array}$ & 4.93 \\
\hline Installment and other & 8.26 & 8.25 & 8.20 & 799 & 7.57 & 7.20 & 7.11 & 7.22 & 739 & 733 \\
\hline Real estate ........... & 19.00 & 20.86 & 22.50 & 23.86 & 24.87 & 24.87 & 24.80 & 24.43 & 25.00 & 25.04 \\
\hline In domestic offices & 18.40 & 20.18 & 21.78 & 23.10 & 24.11 & 24.18 & 24.18 & 23.81 & 24.36 & 24.42 \\
\hline Construction and land development & $\begin{array}{r}10.40 \\
3.90\end{array}$ & $\begin{array}{r}20.10 \\
4.06\end{array}$ & 4.16 & 4.00 & $\begin{array}{r}24.11 \\
3.41\end{array}$ & 2.64 & $\begin{array}{r}24.10 \\
1.99\end{array}$ & $\begin{array}{r}20.01 \\
1.65\end{array}$ & $\begin{array}{r}24.50 \\
1.59\end{array}$ & $\begin{array}{r}24.42 \\
1.63\end{array}$ \\
\hline Farmland $\ldots \ldots \ldots \ldots \ldots \ldots \ldots$ & .47 & .49 & .51 & .51 & $\begin{array}{r}5.41 \\
.53\end{array}$ & $\begin{array}{l}2.04 \\
.56\end{array}$ & .57 & .56 & .56 & .56 \\
\hline One- to four-family residential & 8.22 & 9.21 & 10.15 & 11.21 & 12.27 & 12.91 & 13.49 & 13.74 & 14.41 & 14.42 \\
\hline Home equity $\ldots \ldots \ldots \ldots \ldots$ & $\begin{array}{l}\text { o.22 } \\
\text { n.a. }\end{array}$ & 1.14 & 1.42 & 1.67 & 1.95 & 2.09 & 2.07 & 1.91 & 1.88 & 1.85 \\
\hline Other ........ & n.a. & 8.07 & 8.73 & 9.54 & 10.32 & 10.82 & 11.42 & 11.84 & 12.54 & 12.57 \\
\hline Multifamily residential & .57 & $\begin{array}{r}0.01 \\
.59\end{array}$ & .60 & .62 & .66 & .75 & $\begin{array}{r}11.42 \\
.79\end{array}$ & $\begin{array}{r}11.04 \\
.79\end{array}$ & .81 & .85 \\
\hline Nonfarm nonresidential & 5.25 & 5.83 & 6.36 & 6.76 & 7.23 & 7.32 & 7.33 & 7.07 & 6.97 & 6.96 \\
\hline In foreign offices ........ & 60 & 68 & .72 & .76 & .76 & 69 & 62 & 63 & 65 & .63 \\
\hline Depository institutions & 2.28 & 2.04 & 1.76 & 1.60 & 1.42 & 1.24 & 1.08 & 1.42 & 1.88 & 2.29 \\
\hline Foreign governments & 1.35 & 1.22 & 1.03 & .78 & .75 & .73 & .67 & .41 & .30 & .26 \\
\hline Agricultural production & 1.04 & .98 & .96 & .96 & 1.01 & 1.02 & .99 & 1.00 & .96 & .92 \\
\hline Other loans ........... & 4.98 & 4.52 & 4.31 & 3.93 & 3.60 & 3.50 & 3.56 & 3.34 & 3.15 & 3.36 \\
\hline Lease-financing receivables & 98 & 1.06 & 1.10 & 1.12 & 1.09 & 1.03 & .99 & 1.03 & 1.19 & 1.51 \\
\hline LESS: Unearned income on loans & -.52 & -50 & -48 & -42 & -36 & -28 & -21 & -16 & -.14 & -.12 \\
\hline LEss: Loss reserves $^{1} \ldots \ldots \ldots \ldots$ & -1.40 & -1.61 & -1.52 & -1.57 & -1.62 & -1.60 & -1.51 & -1.36 & -1.27 & -1.21 \\
\hline Securities ............ & 18.34 & 18.45 & 18.39 & 19.09 & 20.70 & 23.52 & 25.37 & 24.27 & 21.94 & 21.00 \\
\hline Investment account & 17.00 & 17.17 & 17.14 & 17.63 & 18.93 & 21.18 & 22.50 & 21.60 & 19.38 & 18.20 \\
\hline Debt .............. & 17.00 & 17.17 & 16.84 & 17.37 & 18.62 & 20.82 & 22.12 & 21.21 & 18.97 & 17.74 \\
\hline U.S. Treasury & 6.02 & 5.60 & $\begin{array}{r}10.84 \\
4.98\end{array}$ & 4.57 & $\begin{array}{r}10.02 \\
5.06\end{array}$ & $\begin{array}{r}20.82 \\
6.49\end{array}$ & $\begin{array}{r}22.12 \\
7.07\end{array}$ & $\begin{array}{r}21.21 \\
6.77\end{array}$ & $\begin{array}{r}10.911 \\
5.25\end{array}$ & $\begin{array}{r}17.14 \\
4.19\end{array}$ \\
\hline \multicolumn{11}{|l|}{ U.S. government agency and } \\
\hline corporation obligations & 4.14 & 4.88 & 6.04 & 7.56 & 8.75 & 9.86 & 10.73 & 10.24 & 9.81 & 9.74 \\
\hline Government-backed mortgage pools & 2.10 & 2.59 & 3.27 & 4.08 & 4.52 & 4.52 & 4.74 & 4.67 & 4.46 & 4.80 \\
\hline Collateralized mortgage obligations & n.a. & n.a. & n.a. & $\begin{array}{l}4.00 \\
1.28\end{array}$ & 2.07 & 3.12 & 3.72 & 3.24 & 2.67 & $\begin{array}{l}4.11 \\
2.11\end{array}$ \\
\hline Other $\ldots \ldots \ldots \ldots \ldots \ldots \ldots \ldots \ldots \ldots$ & 2.04 & 2.29 & 2.77 & 2.20 & 2.16 & 2.21 & 2.27 & 2.33 & 2.68 & 2.83 \\
\hline State and local government & 4.40 & 3.69 & 3.15 & 2.64 & 2.28 & 2.08 & 2.06 & 2.02 & 1.80 & 1.68 \\
\hline Other $\ldots \ldots \ldots \ldots \ldots \ldots$ & $\begin{array}{l}4.40 \\
2.44\end{array}$ & 2.99 & 2.68 & $\begin{array}{l}2.04 \\
2.59\end{array}$ & $\begin{array}{l}2.20 \\
2.53\end{array}$ & $\begin{array}{l}2.00 \\
2.40\end{array}$ & 2.25 & $\begin{array}{l}2.02 \\
2.18\end{array}$ & 2.11 & $\begin{array}{l}1.00 \\
2.13\end{array}$ \\
\hline Equity $^{2}$ & n.a. & n.a. & .29 & .27 & .31 & .37 & .38 & .39 & .41 & .45 \\
\hline Trading account & 1.34 & 1.28 & 1.25 & 1.46 & 1.77 & 2.34 & 2.87 & 2.67 & 2.55 & 2.81 \\
\hline Gross federal funds sold and reverse RPs & 4.57 & 4.55 & 4.33 & 4.46 & 4.58 & 4.54 & 4.27 & 3.82 & 3.93 & 3.82 \\
\hline Interest-bearing balances at depositories . & 5.45 & 5.21 & 4.58 & 3.75 & 3.21 & 2.97 & 2.62 & 2.40 & 2.23 & 2.08 \\
\hline \multirow{3}{*}{$\begin{array}{l}\text { Non-interest-earning assets } \ldots \ldots \ldots \ldots \ldots \ldots \ldots \\
\quad \text { Revaluation gains on off-balance-sheet items }{ }^{3} \\
\text { Other } \ldots \ldots \ldots \ldots \ldots \ldots \ldots \ldots \ldots \ldots \ldots \ldots \ldots\end{array}$} & 12.52 & 12.00 & 12.06 & 12.18 & 11.96 & 11.67 & 11.50 & 13.45 & 13.52 & 13.19 \\
\hline & $\begin{array}{l}12.52 \\
\text { n.a. }\end{array}$ & $\begin{array}{l}\text { n.a. } \\
\text { n.e0 }\end{array}$ & $\begin{array}{l}12.00 \\
\text { n.a. }\end{array}$ & $\begin{array}{l}12.10 \\
\text { n.a. }\end{array}$ & $\begin{array}{l}11.90 \\
\text { n.a. }\end{array}$ & $\begin{array}{l}11.01 \\
\text { n.a. }\end{array}$ & $\begin{array}{l}11.50 \\
\text { n.a. }\end{array}$ & $\begin{array}{r}15.43 \\
2.61\end{array}$ & 2.90 & $\begin{array}{r}15.19 \\
2.24\end{array}$ \\
\hline & 12.52 & 12.00 & 12.06 & 12.18 & 11.96 & 11.67 & 11.50 & 10.84 & 10.62 & 10.95 \\
\hline Liabilities & 93.83 & 93.84 & 93.64 & 93.60 & 93.33 & 92.82 & 92.15 & 92.12 & 91.99 & 91.73 \\
\hline Interest-bearing liabilities & 74.03 & 75.40 & 76.02 & 76.53 & 76.58 & 75.32 & 73.92 & 71.86 & 71.87 & 71.63 \\
\hline Deposits..$\ldots \ldots \ldots \ldots$ & 61.26 & 62.06 & 62.58 & 63.44 & 64.45 & 62.93 & 60.26 & 57.34 & 56.28 & 55.83 \\
\hline In foreign offices & 11.02 & 10.41 & $\begin{array}{r}0.50 \\
9.68\end{array}$ & $\begin{array}{r}0.44 \\
9.26\end{array}$ & 8.55 & 8.37 & 8.32 & $\begin{array}{r}7 . .34 \\
9.39\end{array}$ & 10.27 & 10.01 \\
\hline In domestic offices & 50.24 & 51.66 & 52.90 & 54.18 & 55.90 & 54.56 & 51.94 & 47.96 & 46.01 & 45.83 \\
\hline Other checkable deposits & 6.04 & 6.25 & 6.12 & 6.19 & 6.72 & 7.65 & 8.24 & 7.80 & 6.63 & 4.76 \\
\hline Savings (including MMDAs) & 18.28 & 17.60 & 16.28 & 16.59 & 18.00 & 20.28 & 20.90 & 19.60 & 17.47 & 18.69 \\
\hline Small-denomination time deposits & $\begin{array}{l}10.20 \\
15.06\end{array}$ & 16.25 & $\begin{array}{l}10.20 \\
18.38\end{array}$ & 19.96 & 21.30 & 19.21 & $\begin{array}{l}20.90 \\
16.98\end{array}$ & 15.33 & 16.14 & 15.96 \\
\hline Large-denomination time deposits .. & 10.86 & 11.55 & 12.13 & 11.44 & 9.89 & 7.42 & 5.81 & 5.23 & 5.77 & 6.41 \\
\hline Gross federal funds purchased and RPs & 8.13 & 8.02 & 8.22 & 8.03 & 7.09 & 7.02 & 7.47 & 7.60 & 7.70 & 7.18 \\
\hline Other & 4.64 & 5.31 & 5.22 & 5.07 & 5.03 & 5.37 & 6.19 & 6.92 & 7.88 & 8.62 \\
\hline Non-interest-bearing liabilities & 19.80 & 18.45 & 17.62 & 17.07 & 16.75 & 17.50 & 18.23 & 20.26 & 20.12 & 20.10 \\
\hline 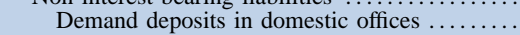 & 15.34 & 14.25 & 13.49 & 12.79 & 12.59 & 13.24 & 13.86 & 13.49 & 12.68 & 12.81 \\
\hline Revaluation losses on off-balance-sheet items ${ }^{3}$ & $\begin{array}{l}15.04 \\
\text { n.a. }\end{array}$ & n.a. & n.a. & n.a. & n.a. & $\begin{array}{l}\text { n.a. } \\
\text { n.24 }\end{array}$ & $\begin{array}{l}15.00 \\
\text { n.a. }\end{array}$ & 2.32 & 2.88 & 2.14 \\
\hline Other $\ldots \ldots \ldots \ldots \ldots \ldots \ldots \ldots \ldots \ldots \ldots \ldots \ldots$ & 4.46 & 4.20 & 4.13 & 4.27 & 4.16 & 4.27 & 4.37 & 4.45 & 4.57 & 5.14 \\
\hline Capital account & 6.17 & 6.16 & 6.36 & 6.40 & 6.67 & 7.18 & 7.85 & 7.88 & 8.01 & 8.27 \\
\hline \multicolumn{11}{|l|}{ Мемо } \\
\hline Commercial real estate loans & n.a. & n.a. & n.a. & n.a. & 11.36 & 10.59 & 9.83 & 9.15 & 9.01 & 9.06 \\
\hline Other real estate owned ...... & .35 & .39 & .39 & .50 & .75 & .82 & .63 & .36 & .19 & .14 \\
\hline \multirow{2}{*}{$\begin{array}{l}\text { Managed liabilities ............ } \\
\text { Average net consolidated assets }\end{array}$} & 35.13 & 35.74 & 35.69 & 34.24 & 30.99 & 28.65 & 28.23 & 29.57 & 32.06 & 32.73 \\
\hline & 2,922 & 3,048 & 3,187 & 3,338 & 3,379 & 3,442 & 3,566 & 3.863 & 4.149 & 4.379 \\
\hline
\end{tabular}




\section{A.2.-Continued}

A. All banks

\begin{tabular}{|c|c|c|c|c|c|c|c|c|c|c|}
\hline Item & 1987 & 1988 & 1989 & 1990 & 1991 & 1992 & 1993 & 1994 & 1995 & 1996 \\
\hline & \multicolumn{10}{|c|}{ Effective interest rate (percent) ${ }^{4}$} \\
\hline \multicolumn{11}{|l|}{ Rates earned } \\
\hline Interest-earning assets & 9.43 & 10.06 & 11.13 & 10.66 & 9.55 & 8.29 & 7.62 & 7.62 & 8.34 & 8.20 \\
\hline Taxable equivalent & 9.67 & 10.26 & 11.29 & 10.79 & 9.66 & 8.39 & 7.72 & 7.71 & 8.41 & 8.27 \\
\hline Loans and leases, gross & 10.23 & 10.86 & 12.03 & 11.48 & 10.37 & 9.21 & 8.69 & 8.63 & 9.27 & 9.10 \\
\hline Net of loss provisions & 8.08 & 9.80 & 10.44 & 9.93 & 8.69 & 7.88 & 7.87 & 8.13 & 8.76 & 8.47 \\
\hline Securities $\ldots \ldots \ldots \ldots \ldots \ldots$ & 8.10 & 8.38 & 8.73 & 8.79 & 8.16 & 7.06 & 6.08 & 5.97 & 6.52 & 6.45 \\
\hline Taxable equivalent & 8.95 & 9.07 & 9.25 & 9.20 & 8.54 & 7.37 & 6.37 & 6.21 & 6.74 & 6.69 \\
\hline Investment account. & 7.95 & 8.07 & 8.56 & 8.66 & 8.23 & 7.14 & 6.07 & 5.80 & 6.36 & 6.38 \\
\hline U.S. government and other debt & 8.19 & 8.25 & 8.80 & 8.92 & 8.40 & 7.21 & 6.08 & 5.81 & 6.43 & 6.50 \\
\hline State and local .............. & 7.27 & 7.39 & 7.45 & 7.37 & 7.25 & 6.83 & 6.26 & 5.88 & 5.82 & 5.57 \\
\hline Equity $^{2} \ldots \ldots \ldots \ldots \ldots$ & n.a. & n.a. & 7.74 & 7.34 & 6.19 & 5.32 & 4.79 & 4.79 & 5.51 & 5.25 \\
\hline Trading account & 10.01 & 12.63 & 11.11 & 10.15 & 7.53 & 6.40 & 6.16 & 7.41 & 7.73 & 6.87 \\
\hline Gross federal funds sold and reverse RPs & 6.57 & 7.52 & 9.17 & 8.06 & 5.67 & 3.59 & 3.04 & 4.26 & 5.63 & 5.22 \\
\hline Interest-bearing balances at depositories . & 7.55 & 8.71 & 10.59 & 9.96 & 8.44 & 7.32 & 6.61 & 5.70 & 6.84 & 6.22 \\
\hline \multicolumn{11}{|l|}{ Rates paid } \\
\hline Interest-bearing liabilities & 6.76 & 7.28 & 8.53 & 8.04 & 6.52 & 4.76 & 4.02 & 4.02 & 4.99 & 4.84 \\
\hline Interest-bearing deposits & 5.80 & 6.23 & 7.18 & 6.90 & 5.73 & 4.04 & 3.22 & 3.12 & 4.00 & 4.02 \\
\hline In foreign offices .... & 7.90 & 8.91 & 10.87 & 10.71 & 8.54 & 7.32 & 6.82 & 5.59 & 6.12 & 5.55 \\
\hline In domestic offices . & 5.38 & 5.75 & 6.57 & 6.30 & 5.34 & 3.59 & 2.72 & 2.71 & 3.60 & 3.71 \\
\hline Other checkable deposits & 4.55 & 4.77 & 4.83 & 4.78 & 4.33 & 2.71 & 1.99 & 1.86 & 2.07 & 2.05 \\
\hline Savings (including MMDAs) & 5.29 & 5.55 & 6.18 & 5.98 & 5.09 & 3.26 & 2.50 & 2.58 & 3.19 & 3.01 \\
\hline Large-denomination CDs ... & 6.88 & 7.47 & 8.67 & 8.03 & 6.67 & 4.91 & 4.00 & 4.10 & 5.47 & 5.42 \\
\hline Other time deposits ...... & 6.99 & 7.34 & 8.29 & 7.96 & 6.89 & 5.17 & 4.20 & 4.18 & 5.45 & 5.43 \\
\hline \multirow[t]{2}{*}{ Gross federal funds purchased and RPs } & 6.52 & 7.43 & 9.20 & 7.96 & 5.72 & 3.65 & 3.07 & 4.19 & 5.65 & 5.16 \\
\hline & \multicolumn{10}{|c|}{ Income and expense as a percentage of average net consolidated assets } \\
\hline Gross interest income & 8.39 & 9.00 & 9.95 & 9.59 & 8.58 & 7.47 & 6.87 & 6.66 & 7.30 & 7.21 \\
\hline Taxable equivalent & 8.59 & 9.18 & 10.08 & 9.70 & 8.67 & 7.55 & 6.95 & 6.73 & 7.36 & 7.26 \\
\hline Loans .............. & 6.18 & 6.66 & 7.46 & 7.15 & 6.34 & 5.41 & 5.01 & 4.92 & 5.48 & 5.51 \\
\hline Securities & 1.35 & 1.38 & 1.47 & 1.53 & 1.56 & 1.51 & 1.37 & 1.25 & 1.23 & 1.16 \\
\hline Gross federal funds sold and reverse RPs & .31 & .35 & .41 & .38 & .27 & .17 & .13 & .17 & .24 & .21 \\
\hline Other $\ldots \ldots \ldots \ldots \ldots \ldots \ldots \ldots \ldots \ldots \ldots$ & .54 & .61 & .61 & .54 & .41 & .37 & .36 & .33 & .35 & .32 \\
\hline Gross interest expense & 4.97 & 5.46 & 6.44 & 6.14 & 4.97 & 3.57 & 2.96 & 2.87 & 3.57 & 3.45 \\
\hline Deposits . ............ & 3.96 & 4.28 & 4.94 & 4.83 & 4.11 & 2.88 & 2.23 & 2.05 & 2.54 & 2.47 \\
\hline Gross federal funds purchased and RPs & .55 & .62 & .78 & .68 & .42 & $\begin{array}{r}2.00 \\
.27\end{array}$ & .24 & .32 & .44 & .39 \\
\hline 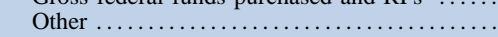 & .46 & .56 & .71 & .62 & .43 & .42 & .50 & .50 & .58 & .60 \\
\hline Net interest income & 3.42 & 3.54 & 3.51 & 3.46 & 3.61 & 3.90 & 3.90 & 3.79 & 3.73 & 3.76 \\
\hline Taxable equivalent & 3.63 & 3.72 & 3.65 & 3.57 & 3.71 & 3.99 & 3.99 & 3.86 & 3.79 & 3.81 \\
\hline Loss provisioning 5 & 1.30 & .65 & .98 & .97 & 1.03 & .78 & .47 & .28 & .30 & .38 \\
\hline Noninterest income & 1.43 & 1.50 & 1.62 & 1.67 & 1.79 & 1.95 & 2.13 & 2.00 & 2.02 & 2.19 \\
\hline Service charges on deposits & .30 & .31 & .32 & .34 & .38 & .41 & .42 & .40 & .39 & .39 \\
\hline Income from fiduciary activities & .24 & .25 & .26 & .27 & .28 & .30 & .31 & .31 & .31 & .32 \\
\hline Trading income $. . . . . \ldots \ldots . .$. & .12 & .12 & .13 & .15 & .18 & .18 & .26 & .16 & .15 & .17 \\
\hline Other $\ldots \ldots \ldots \ldots \ldots \ldots \ldots \ldots$ & .77 & .82 & .91 & .91 & .96 & 1.05 & 1.14 & 1.13 & 1.17 & 1.30 \\
\hline Noninterest expense & 3.35 & 3.38 & 3.42 & 3.49 & 3.73 & 3.87 & 3.94 & 3.76 & 3.65 & 3.73 \\
\hline Salaries, wages, and employee benefits & 1.55 & 1.55 & 1.55 & 1.56 & 1.59 & 1.62 & 1.64 & 1.58 & 1.54 & 1.55 \\
\hline Expenses of premises and fixed assets & .53 & .53 & .52 & .53 & .53 & .53 & .52 & .49 & .48 & .48 \\
\hline 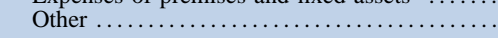 & 1.27 & 1.31 & 1.35 & 1.41 & 1.61 & 1.72 & 1.78 & 1.68 & 1.62 & 1.70 \\
\hline Net noninterest expense & 1.91 & 1.88 & 1.80 & 1.82 & 1.94 & 1.92 & 1.82 & 1.75 & 1.62 & 1.54 \\
\hline Realized gains on investment account securities . & .05 & .01 & .03 & .01 & .09 & .11 & .09 & -.01 & .01 & .03 \\
\hline Income before taxes and extraordinary items & .26 & 1.02 & .76 & .68 & .73 & 1.32 & 1.70 & 1.74 & 1.81 & 1.86 \\
\hline Taxes $\ldots \ldots \ldots \ldots \ldots \ldots$ & .19 & .33 & .30 & .23 & .25 & .42 & .56 & .58 & .63 & .65 \\
\hline Extraordinary items & .01 & .03 & .01 & .02 & .03 & .01 & .06 & $*$ & $*$ & $*$ \\
\hline Net income (return on assets) & .08 & .71 & .47 & .47 & .51 & .91 & 1.20 & & 1.18 & \\
\hline Cash dividends declared .... & .36 & .44 & .44 & .42 & .45 & .41 & .62 & .73 & $\begin{array}{r}1.10 \\
.75\end{array}$ & $\begin{array}{r}1.21 \\
.91\end{array}$ \\
\hline Retained income ........... & -.29 & .28 & .02 & .05 & .07 & .50 & .59 & .42 & .43 & .29 \\
\hline Memo: Return on equity & 1.29 & 11.61 & 7.33 & 7.29 & 7.71 & 12.66 & 15.34 & 14.64 & 14.71 & 14.60 \\
\hline
\end{tabular}

* In absolute value, less than 0.005 percent.

n.a. Not available. MMDA Money market deposit account. RP Repurchase agreement. CD Certificate of deposit.

1. Includes allocated transfer risk reserve.

2. As in the Call Report, equity securities are combined with "other debt securities" before 1989 .

3. Before 1994, the netted value of off-balance-sheet items appeared in "trading account securities" if a gain and "other non-interest-bearing liabilities" if a loss.

4. Where possible, based on the average of quarterly balance sheet data reported on schedule RC-K of the quarterly Call Report.

5. Includes provisioning for allocated transfer risk. 
A.2. Portfolio composition, interest rates, and income and expense, all insured domestic commercial banks, 1987-96 B. Ten largest banks by assets

\begin{tabular}{|c|c|c|c|c|c|c|c|c|c|c|}
\hline Item & 1987 & 1988 & 1989 & 1990 & 1991 & 1992 & 1993 & 1994 & 1995 & 1996 \\
\hline & \multicolumn{10}{|c|}{ Balance sheet items as a percentage of average net consolidated assets } \\
\hline Interest-earning assets & 85.14 & 85.22 & 85.16 & 84.85 & 85.41 & 85.16 & 84.79 & 76.97 & 77.02 & 79.94 \\
\hline Loans and leases, net & 59.36 & 58.69 & 59.66 & 61.69 & 62.14 & 58.34 & 55.57 & 49.91 & 50.05 & 53.51 \\
\hline Commercial and industrial & 24.53 & 23.36 & 22.61 & 22.91 & 22.42 & 20.32 & 18.65 & 16.43 & 16.16 & 17.17 \\
\hline U.S. addressees ....... & 13.31 & 13.01 & 13.18 & 13.39 & 13.44 & 12.00 & 10.75 & 9.16 & 8.66 & 9.59 \\
\hline Foreign addressees . & 11.22 & 10.36 & 9.43 & 9.53 & 8.97 & 8.32 & 7.90 & 7.27 & 7.50 & 7.59 \\
\hline Consumer .......... & 6.41 & 6.19 & 6.21 & 6.87 & 7.20 & 7.31 & 7.33 & 6.59 & 6.60 & 6.22 \\
\hline Credit card & 2.34 & 2.08 & 1.99 & 2.20 & 2.53 & 2.61 & 2.50 & 2.28 & 1.96 & 1.23 \\
\hline Installment and other & 4.07 & 4.10 & 4.22 & 4.67 & 4.67 & 4.70 & 4.83 & 4.31 & 4.65 & 4.99 \\
\hline Real estate $\ldots \ldots \ldots \ldots$ & 13.97 & 15.46 & 18.02 & 20.56 & 21.68 & 19.93 & 18.54 & 16.21 & 15.82 & 16.53 \\
\hline In domestic offices & 11.69 & 12.80 & 15.05 & 17.36 & 18.37 & 17.07 & 15.99 & 13.80 & 13.48 & 14.44 \\
\hline Construction and land development & 3.21 & 3.48 & 3.60 & 3.79 & 3.42 & 2.48 & 1.59 & .84 & .58 & .51 \\
\hline Farmland $\ldots \ldots \ldots \ldots \ldots \ldots \ldots \ldots$ & .06 & .06 & .08 & .08 & .08 & .07 & .07 & .06 & .06 & .06 \\
\hline One- to four-family residential & 5.17 & 5.83 & 7.45 & 9.31 & 10.34 & 10.08 & 10.29 & 9.69 & 9.62 & 10.43 \\
\hline Home equity $\ldots \ldots \ldots \ldots$ & n.a. & .76 & 1.04 & 1.31 & 1.63 & 1.63 & 1.60 & 1.40 & 1.40 & 1.53 \\
\hline Other $\ldots \ldots$. . & n.a. & 5.07 & 6.41 & 8.00 & 8.71 & 8.46 & 8.68 & 8.29 & 8.22 & 8.90 \\
\hline Multifamily residential & .61 & .65 & .68 & .68 & .57 & .58 & .53 & .41 & .38 & .38 \\
\hline Nonfarm nonresidential & 2.63 & 2.78 & 3.23 & 3.51 & 3.95 & 3.86 & 3.51 & 2.79 & 2.83 & 3.05 \\
\hline In foreign offices...$\ldots \ldots$ & 2.28 & 2.66 & 2.97 & 3.20 & 3.32 & 2.85 & 2.55 & 2.41 & 2.35 & 2.09 \\
\hline Depository institutions & 5.18 & 5.21 & 4.56 & 3.64 & 3.05 & 2.56 & 2.35 & 3.37 & 4.95 & 6.06 \\
\hline Foreign governments. & 3.64 & 3.63 & 3.34 & 2.76 & 2.88 & 2.75 & 2.46 & 1.27 & .90 & .69 \\
\hline Agricultural production & .36 & .33 & .31 & .31 & .31 & .28 & .27 & .25 & 21 & .23 \\
\hline Other loans ............. & 6.51 & 6.23 & 6.36 & 6.05 & 5.61 & 6.05 & 6.82 & 6.44 & 5.85 & 6.42 \\
\hline Lease-financing receivables & 1.38 & 1.44 & 1.49 & 1.60 & 1.68 & 1.51 & 1.30 & 1.14 & 1.14 & 1.59 \\
\hline LESS: Unearned income on loans & -.41 & -.43 & -.45 & -.39 & -.35 & -.27 & -.21 & -.16 & -.14 & -.11 \\
\hline LESS: Loss reserves ${ }^{1} \ldots \ldots \ldots \ldots$ & -2.22 & -2.74 & -2.77 & -2.63 & -2.34 & -2.08 & -1.94 & -1.63 & -1.45 & -1.31 \\
\hline Securities ............ & 12.59 & 12.96 & 13.13 & 14.03 & 15.58 & 19.13 & 22.74 & 20.43 & 19.53 & 19.83 \\
\hline Investment account & 8.19 & 8.67 & 9.05 & 9.22 & 9.38 & 10.70 & 12.45 & 11.68 & 10.65 & 10.60 \\
\hline Debt .............. & 8.19 & 8.67 & 8.83 & 8.98 & 9.08 & 10.36 & 12.08 & 11.30 & 10.27 & 10.22 \\
\hline U.S. Treasury & 1.47 & 1.41 & 1.29 & 1.09 & 1.35 & 2.30 & 2.39 & 2.17 & 2.03 & 1.93 \\
\hline \multicolumn{11}{|l|}{ U.S. government agency and } \\
\hline corporation obligations & 1.54 & 1.94 & 2.29 & 2.91 & 3.46 & 4.45 & 6.14 & 5.16 & 4.46 & 4.59 \\
\hline Government-backed mortgage pools & 1.47 & 1.84 & 2.07 & 2.24 & 2.26 & 2.43 & 3.30 & 2.79 & 2.89 & 3.58 \\
\hline Collateralized mortgage obligations . & n.a. & n.a. & n.a. & .55 & 1.12 & 1.97 & 2.76 & 2.31 & 1.50 & .95 \\
\hline Other $\ldots \ldots \ldots \ldots \ldots \ldots \ldots \ldots$ & .07 & .10 & .22 & .13 & .08 & .05 & .08 & .06 & .08 & .06 \\
\hline State and local government & 1.93 & 1.80 & 1.58 & 1.08 & .77 & .66 & .59 & .60 & .49 & .39 \\
\hline Other $\ldots \ldots \ldots \ldots \ldots \ldots \ldots$ & 3.25 & 3.52 & 3.68 & 3.90 & 3.50 & 2.95 & 2.97 & 3.37 & 3.29 & 3.31 \\
\hline Equity $^{2}$ & n.a. & n.a. & .22 & .24 & .30 & .33 & .36 & .38 & .38 & .38 \\
\hline Trading account & 4.40 & 4.29 & 4.08 & 4.81 & 6.19 & 8.43 & 10.30 & 8.74 & 8.88 & 9.23 \\
\hline Gross federal funds sold and reverse RPs & 3.91 & 4.61 & 4.12 & 2.88 & 2.96 & 3.23 & 2.71 & 2.68 & 3.20 & 3.10 \\
\hline Interest-bearing balances at depositories .. & 9.28 & 8.97 & 8.26 & 6.25 & 4.74 & 4.45 & 3.76 & 3.95 & 4.25 & 3.50 \\
\hline Non-interest-earning assets ............. & 14.86 & 14.78 & 14.84 & 15.15 & 14.59 & 14.84 & 15.21 & 23.03 & 22.98 & 20.06 \\
\hline Revaluation gains on off-balance-sheet items $^{3}$ & n.a. & n.a. & n.a. & n.a. & n.a. & n.a. & n.a. & 9.89 & 10.77 & 7.63 \\
\hline Other $\ldots \ldots \ldots \ldots \ldots \ldots \ldots \ldots \ldots \ldots \ldots \ldots \ldots \ldots$ & 14.86 & 14.78 & 14.84 & 15.15 & 14.59 & 14.84 & 15.21 & 13.14 & 12.21 & 12.43 \\
\hline Liabilities & 95.58 & 95.41 & 95.11 & 95.29 & 94.97 & 94.44 & 93.24 & 93.42 & 93.59 & 93.04 \\
\hline Interest-bearing liabilities & 73.08 & 73.76 & 74.17 & 73.97 & 74.62 & 73.08 & 71.56 & 64.33 & 63.37 & 64.45 \\
\hline 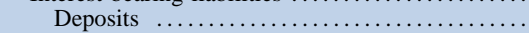 & 57.46 & 57.67 & 57.56 & 57.95 & 57.67 & 55.73 & 52.91 & 48.20 & 47.49 & 47.87 \\
\hline In foreign offices & 32.60 & 31.49 & 30.08 & 29.66 & 28.47 & 27.16 & 25.51 & 26.10 & 28.36 & 26.41 \\
\hline In domestic offices & 24.86 & 26.18 & 27.49 & 28.28 & 29.19 & 28.56 & 27.41 & 22.10 & 19.12 & 21.46 \\
\hline Other checkable deposits & 2.45 & 2.68 & 2.70 & 2.74 & 3.00 & 3.38 & 3.45 & 2.91 & 2.30 & 1.61 \\
\hline Savings (including MMDAs) & 11.04 & 11.42 & 11.32 & 12.05 & 13.50 & 14.91 & 15.33 & 12.70 & 10.56 & 12.31 \\
\hline Small-denomination time deposits & 4.55 & 5.03 & 5.64 & 6.16 & 6.55 & 5.72 & 5.09 & 3.98 & 4.04 & 4.68 \\
\hline Large-denomination time deposits & 6.82 & 7.05 & 7.82 & 7.33 & 6.14 & 4.56 & 3.53 & 2.51 & 2.23 & 2.86 \\
\hline Gross federal funds purchased and RPs . & 6.89 & 6.40 & 6.72 & 6.90 & 6.80 & 6.19 & 6.70 & 5.83 & 6.17 & 5.88 \\
\hline Other $\ldots \ldots \ldots \ldots \ldots \ldots \ldots \ldots \ldots \ldots \ldots \ldots \ldots \ldots \ldots \ldots \ldots \ldots$ & 8.74 & 9.69 & 9.89 & 9.13 & 10.15 & 11.16 & 11.94 & 10.29 & 9.71 & 10.69 \\
\hline Non-interest-bearing liabilities & 22.50 & 21.65 & 20.94 & 21.32 & 20.35 & 21.36 & 21.68 & 29.09 & 30.22 & 28.59 \\
\hline Demand deposits in domestic offices ........ & 12.64 & 11.93 & 11.60 & 10.93 & 10.36 & 11.05 & 11.27 & 10.15 & 8.88 & 9.73 \\
\hline Revaluation losses on off-balance-sheet items ${ }^{3}$. & n.a. & n.a. & n.a. & n.a. & n.a. & n.a. & n.a. & 8.75 & 10.68 & 7.27 \\
\hline Other $\ldots \ldots \ldots \ldots \ldots \ldots \ldots \ldots \ldots \ldots \ldots \ldots \ldots \ldots$ & 9.86 & 9.71 & 9.34 & 10.39 & 9.99 & 10.30 & 10.41 & 10.20 & 10.66 & 11.59 \\
\hline Capital account & 4.42 & 4.59 & 4.89 & 4.71 & 5.03 & 5.56 & 6.76 & 6.58 & 6.41 & 6.96 \\
\hline \multicolumn{11}{|l|}{ Мемо } \\
\hline Commercial real estate loans & n.a. & n.a. & n.a. & n.a. & 8.48 & 7.43 & 5.92 & 4.24 & 4.02 & 4.28 \\
\hline Other real estate owned ..... & .21 & .22 & .23 & .42 & .78 & 1.13 & 1.02 & .58 & .27 & .18 \\
\hline \multirow{3}{*}{$\begin{array}{l}\text { Managed liabilities } \ldots \ldots \ldots \ldots \\
\text { Average net consolidated assets } \\
\text { (billions of dollars) } \ldots \ldots \ldots\end{array}$} & 56.79 & 56.34 & 56.24 & 54.74 & 53.18 & 50.76 & 49.17 & 46.16 & 47.89 & 47.33 \\
\hline & & & & & & & & & & \\
\hline & 691 & 685 & 693 & 725 & 717 & 775 & 818 & 949 & 1,051 & 1,189 \\
\hline
\end{tabular}




\section{A.2.-Continued}

B. Ten largest banks by assets

\begin{tabular}{|c|c|c|c|c|c|c|c|c|c|c|}
\hline Item & 1987 & 1988 & 1989 & 1990 & 1991 & 1992 & 1993 & 1994 & 1995 & 1996 \\
\hline & \multicolumn{10}{|c|}{ Effective interest rate (percent) $)^{4}$} \\
\hline \multicolumn{11}{|l|}{ Rates earned } \\
\hline Interest-earning assets & 9.56 & 10.76 & 12.31 & 11.65 & 9.92 & 8.67 & 8.16 & 8.15 & 8.20 & 7.77 \\
\hline Taxable equivalent & 9.59 & 10.88 & 12.31 & 11.70 & 9.95 & 8.72 & 8.20 & 8.18 & 8.22 & 7.79 \\
\hline Loans and leases, gross & 10.13 & 11.35 & 13.19 & 12.29 & 10.46 & 9.36 & 9.07 & 8.89 & 8.84 & 8.38 \\
\hline Net of loss provisions & 6.63 & 10.70 & 10.87 & 11.10 & 8.58 & 7.50 & 7.95 & 8.38 & 8.62 & 8.17 \\
\hline Securities ................. & 9.49 & 10.54 & 10.11 & 9.85 & 8.52 & 7.38 & 6.69 & 7.10 & 7.41 & 6.82 \\
\hline Taxable equivalent & 9.65 & 11.06 & 10.08 & 10.00 & 8.63 & 7.54 & 6.77 & 7.19 & 7.47 & 6.87 \\
\hline Investment account & 8.70 & 8.70 & 9.20 & 9.34 & 8.99 & 7.96 & 6.90 & 6.58 & 7.06 & 6.75 \\
\hline U.S. government and other debt & 9.07 & 8.95 & 9.56 & 9.68 & 9.29 & 8.13 & 6.99 & 6.70 & 7.22 & 6.90 \\
\hline State and local .................. & 7.52 & 7.74 & 7.69 & 7.54 & 7.67 & 7.40 & 6.99 & 6.37 & 6.23 & 5.73 \\
\hline Equity $^{2} \ldots \ldots$ & n.a. & n.a. & 6.81 & 5.82 & 4.22 & 4.04 & 3.72 & 3.27 & 4.03 & 3.84 \\
\hline Trading account & 10.96 & 14.33 & 12.13 & 10.75 & 7.84 & 6.69 & 6.45 & 7.79 & 7.83 & 6.91 \\
\hline Gross federal funds sold and reverse RPs & 6.13 & 7.31 & 8.98 & 8.01 & 5.60 & 3.65 & 3.02 & 4.52 & 5.20 & 4.99 \\
\hline Interest-bearing balances at depositories .. & 7.68 & 9.13 & 10.88 & 11.06 & 10.05 & 9.29 & 8.34 & 7.27 & 7.15 & 6.71 \\
\hline \multicolumn{11}{|l|}{ Rates paid } \\
\hline Interest-bearing liabilities & 7.83 & 8.75 & 10.74 & 10.18 & 7.71 & 6.17 & 5.60 & 5.44 & 5.88 & 5.46 \\
\hline Interest-bearing deposits & 6.62 & 7.43 & 8.79 & 8.64 & 6.75 & 5.05 & 4.23 & 4.07 & 4.76 & 4.46 \\
\hline In foreign offices ..... & 8.00 & 9.00 & 10.96 & 11.11 & 8.76 & 7.55 & 6.87 & 6.04 & 6.07 & 5.62 \\
\hline In domestic offices . & 5.02 & 5.71 & 6.64 & 6.22 & 4.98 & 2.92 & 2.11 & 2.08 & 3.06 & 3.16 \\
\hline Other checkable deposits & 3.26 & 4.43 & 4.40 & 4.35 & 3.93 & 1.96 & 1.28 & 1.11 & 1.29 & 1.39 \\
\hline Savings (including MMDAs) & 5.13 & 5.55 & 6.49 & 6.21 & 5.09 & 2.95 & 2.14 & 2.35 & 3.11 & 2.80 \\
\hline Large-denomination CDs $\ldots$ & 7.29 & 7.75 & 8.87 & 7.96 & 6.50 & 4.66 & 3.55 & 3.14 & 3.73 & 4.65 \\
\hline Other time deposits . & 6.38 & 7.11 & 8.26 & 7.76 & 6.09 & 3.81 & 3.01 & 2.81 & 5.08 & 4.67 \\
\hline \multirow[t]{2}{*}{ Gross federal funds purchased and RPs } & 6.52 & 7.43 & 9.27 & 7.75 & 5.98 & 4.04 & 3.26 & 4.05 & 5.22 & 4.96 \\
\hline & \multicolumn{10}{|c|}{ Income and expense as a percentage of average net consolidated assets } \\
\hline Gross interest income & 8.45 & 9.52 & 10.82 & 10.37 & 8.77 & 7.68 & 7.22 & 6.38 & 6.42 & 6.29 \\
\hline Taxable equivalent & 8.47 & 9.63 & 10.83 & 10.43 & 8.80 & 7.72 & 7.25 & 6.40 & 6.43 & 6.31 \\
\hline Loans $\ldots . . . \ldots \ldots . . . .$. & 6.23 & 6.93 & 8.23 & 7.96 & 6.77 & 5.65 & 5.22 & 4.49 & 4.44 & 4.52 \\
\hline Securities & .71 & .75 & .83 & .86 & .84 & .85 & .86 & .77 & .75 & .72 \\
\hline Gross federal funds sold and reverse RPs & .29 & .40 & .37 & .25 & .17 & .14 & .11 & .15 & .21 & .19 \\
\hline Other & 1.22 & 1.44 & 1.39 & 1.30 & .98 & 1.05 & 1.04 & .97 & 1.00 & .88 \\
\hline Gross interest expense . & 5.77 & 6.51 & 8.01 & 7.65 & 5.81 & 4.54 & 4.06 & 3.52 & 3.74 & 3.53 \\
\hline Deposits ............. & 4.18 & 4.56 & 5.37 & 5.41 & 4.23 & 3.09 & 2.48 & 2.15 & 2.43 & 2.27 \\
\hline Gross federal funds purchase & .52 & .58 & .72 & .64 & .43 & .28 & .24 & .24 & .35 & .31 \\
\hline Other ................... & 1.07 & 1.37 & 1.92 & 1.60 & 1.15 & 1.17 & 1.35 & 1.13 & .95 & .95 \\
\hline Net interest income . & 2.68 & 3.01 & 2.82 & 2.72 & 2.96 & 3.15 & 3.16 & 2.86 & 2.68 & 2.76 \\
\hline Taxable equivalent & 2.71 & 3.12 & 2.82 & 2.77 & 2.99 & 3.18 & 3.19 & 2.88 & 2.70 & 2.78 \\
\hline Loss provisioning 5 & 2.15 & .40 & 1.45 & .77 & 1.21 & 1.12 & .64 & .26 & .11 & .11 \\
\hline Noninterest income & 1.94 & 2.07 & 2.19 & 2.27 & 2.40 & 2.59 & 2.99 & 2.33 & 2.16 & 2.35 \\
\hline Service charges on deposits & .16 & .19 & .22 & .23 & .26 & .30 & .30 & .26 & .25 & .28 \\
\hline Income from fiduciary activities & .23 & .23 & .27 & .31 & .33 & .37 & .39 & .37 & .30 & .31 \\
\hline Trading income $\ldots \ldots \ldots \ldots \ldots \ldots$ & .40 & .41 & .42 & .52 & .64 & .66 & .91 & .53 & .46 & .52 \\
\hline Other $\ldots \ldots \ldots \ldots$ & 1.16 & 1.24 & 1.29 & 1.21 & 1.16 & 1.27 & 1.38 & 1.18 & 1.15 & 1.23 \\
\hline Noninterest expense & 3.20 & 3.29 & 3.43 & 3.55 & 3.83 & 3.86 & 4.13 & 3.56 & 3.32 & 3.60 \\
\hline Salaries, wages, and employee benefits & 1.60 & 1.63 & 1.66 & 1.74 & 1.79 & 1.78 & 1.88 & 1.65 & 1.58 & 1.58 \\
\hline Expenses of premises and fixed assets & .58 & .60 & .62 & .65 & .66 & .65 & .66 & .55 & .50 & .50 \\
\hline Other . & 1.03 & 1.05 & 1.15 & 1.16 & 1.38 & 1.43 & 1.59 & 1.36 & 1.24 & 1.52 \\
\hline Net noninterest expense & 1.26 & 1.21 & 1.24 & 1.28 & 1.44 & 1.27 & 1.14 & 1.23 & 1.16 & 1.24 \\
\hline Realized gains on investment account securities . & .07 & .03 & .03 & .02 & .04 & .11 & .13 & .02 & .03 & .05 \\
\hline Income before taxes and extraordinary items & -.66 & 1.43 & .16 & .69 & .34 & .87 & 1.50 & 1.39 & 1.44 & 1.45 \\
\hline Taxes & .14 & .44 & .38 & .27 & .17 & .26 & .53 & .48 & .55 & .53 \\
\hline Extraordinary items & $*$ & .08 & .03 & .06 & .03 & * & .16 & * & * & * \\
\hline Net income (return on assets) & -.80 & 1.07 & -.19 & .48 & .21 & .61 & 1.13 & .91 & .88 & .93 \\
\hline Cash dividends declared & .28 & .38 & .37 & .26 & .21 & .18 & .28 & .58 & .57 & .73 \\
\hline Retained income . & -1.08 & .69 & -.57 & .21 & * & .43 & .85 & .33 & .31 & .19 \\
\hline Memo: Return on equity . & -18.11 & 23.30 & -3.92 & 10.13 & 4.23 & 10.91 & 16.75 & 13.86 & 13.78 & 13.34 \\
\hline
\end{tabular}

* In absolute value, less than 0.005 percent.

n.a. Not available. MMDA Money market deposit account. RP Repurchase agreement. CD Certificate of deposit.

1. Includes allocated transfer risk reserve.

2. As in the Call Report, equity securities are combined with "other debt securities" before 1989 .

3. Before 1994, the netted value of off-balance-sheet items appeared in "trading account securities" if a gain and "other non-interest-bearing liabilities" if a loss.

4. Where possible, based on the average of quarterly balance sheet data reported on schedule RC-K of the quarterly Call Report.

5. Includes provisioning for allocated transfer risk. 
A.2. Portfolio composition, interest rates, and income and expense, all insured domestic commercial banks, 1987-96 C. Banks ranked 11th through 100th by assets

\begin{tabular}{|c|c|c|c|c|c|c|c|c|c|c|}
\hline Item & 1987 & 1988 & 1989 & 1990 & 1991 & 1992 & 1993 & 1994 & 1995 & 1996 \\
\hline & \multicolumn{10}{|c|}{ Balance sheet items as a percentage of average net consolidated assets } \\
\hline Interest-earning assets & 86.20 & 87.23 & 86.91 & 86.81 & 86.88 & 87.97 & 88.36 & 88.16 & 88.31 & 87.75 \\
\hline Loans and leases, net & 61.70 & 61.99 & 62.61 & 61.22 & 60.08 & 58.30 & 57.33 & 58.56 & 62.68 & 64.24 \\
\hline Commercial and industrial & 23.72 & 23.45 & 22.75 & 21.76 & 20.53 & 18.83 & 18.03 & 18.03 & 19.26 & 18.95 \\
\hline U.S. addressees . . . . . . . . & 21.22 & 21.43 & 21.23 & 20.44 & 19.30 & 17.78 & 17.05 & 16.99 & 18.10 & 17.71 \\
\hline Foreign addressees & 2.50 & 2.02 & 1.53 & 1.33 & 1.24 & 1.05 & .98 & 1.04 & 1.16 & 1.24 \\
\hline Consumer $\ldots \ldots \ldots \ldots$ & 11.73 & 12.20 & 12.97 & 12.25 & 11.66 & 11.72 & 11.47 & 12.62 & 14.23 & 15.66 \\
\hline Credit card & 4.40 & 4.85 & 5.82 & 5.48 & 5.04 & 5.16 & 5.23 & 5.99 & 7.34 & 8.26 \\
\hline Installment and other & 7.33 & 7.35 & 7.16 & 6.76 & 6.62 & 6.56 & 6.24 & 6.63 & 6.89 & 7.40 \\
\hline Real estate .......... & 16.05 & 17.94 & 19.09 & 20.21 & 21.51 & 21.89 & 22.11 & 22.26 & 23.25 & 23.27 \\
\hline In domestic offices & 15.83 & 17.65 & 18.85 & 20.04 & 21.37 & 21.78 & 22.01 & 22.17 & 23.10 & 23.10 \\
\hline Construction and land development & 5.24 & 5.27 & 5.25 & 4.91 & 4.00 & 3.02 & 2.08 & 1.63 & 1.50 & 1.55 \\
\hline Farmland $\ldots \ldots \ldots \ldots \ldots \ldots \ldots$ & .10 & .11 & .12 & .12 & .12 & .14 & .13 & .14 & .13 & .13 \\
\hline One- to four-family residential & 5.88 & 6.85 & 7.54 & 8.53 & 10.17 & 11.36 & 12.30 & 12.98 & 14.16 & 14.16 \\
\hline Home equity $\ldots \ldots \ldots \ldots \ldots$ & n.a. & 1.17 & 1.41 & 1.67 & 2.07 & 2.50 & 2.54 & 2.33 & 2.19 & 2.08 \\
\hline Other $\ldots . .$. & n.a. & 5.68 & 6.13 & 6.86 & 8.10 & 8.85 & 9.76 & 10.65 & 11.97 & 12.08 \\
\hline Multifamily residential & .39 & .43 & .45 & .46 & .54 & .66 & .71 & .71 & .77 & .89 \\
\hline Nonfarm nonresidential & 4.22 & 4.99 & 5.49 & 6.01 & 6.53 & 6.61 & 6.79 & 6.72 & 6.54 & 6.37 \\
\hline In foreign offices $\ldots \ldots \ldots$. & .22 & .29 & .24 & .18 & .14 & .11 & .10 & .09 & .15 & .16 \\
\hline Depository institutions & 2.51 & 1.84 & 1.55 & 1.57 & 1.58 & 1.43 & 1.30 & 1.49 & 1.59 & 1.50 \\
\hline Foreign governments . & 1.53 & 1.22 & .88 & .52 & .39 & .33 & .30 & .28 & .20 & .20 \\
\hline Agricultural production & .30 & .29 & .29 & .28 & .31 & .31 & .29 & .29 & .26 & .28 \\
\hline Other loans ........... & 6.25 & 5.54 & 5.17 & 4.82 & 4.55 & 4.28 & 4.05 & 3.47 & 3.32 & 3.30 \\
\hline Lease-financing receivables & 1.52 & 1.69 & 1.73 & 1.67 & 1.53 & 1.49 & 1.47 & 1.60 & 1.96 & 2.41 \\
\hline LESS: Unearned income on loans & -.40 & -.37 & -.34 & -.26 & -.22 & -.17 & -.11 & -.07 & -.07 & -.06 \\
\hline LESs: Loss reserves ${ }^{1} \ldots \ldots \ldots \ldots$ & -1.51 & -1.80 & -1.48 & -1.60 & -1.76 & -1.79 & -1.60 & -1.41 & -1.32 & -1.27 \\
\hline Securities $\ldots \ldots \ldots \ldots$. & 15.26 & 15.54 & 15.21 & 16.19 & 17.38 & 20.38 & 21.97 & 21.19 & 18.64 & 16.87 \\
\hline Investment account & 14.45 & 14.73 & 14.38 & 15.32 & 16.25 & 19.24 & 20.60 & 19.82 & 17.88 & 16.06 \\
\hline Debt $\ldots \ldots \ldots \ldots$ & 14.45 & 14.73 & 14.16 & 15.14 & 16.02 & 18.99 & 20.34 & 19.50 & 17.51 & 15.62 \\
\hline U.S. Treasury $\ldots \ldots \ldots \ldots \ldots$ & 5.06 & 4.89 & 4.10 & 3.42 & 3.78 & 5.88 & 7.05 & 6.85 & 4.82 & 3.34 \\
\hline \multicolumn{11}{|l|}{ U.S. government agency and } \\
\hline corporation obligations & 3.13 & 3.58 & 5.01 & 7.42 & 8.43 & 9.26 & 9.55 & 9.28 & 9.40 & 9.12 \\
\hline Government-backed mortgage pools & 2.36 & 2.96 & 4.03 & 5.32 & 5.38 & 5.22 & 5.21 & 5.30 & 5.06 & 5.42 \\
\hline Collateralized mortgage obligations . & n.a. & n.a. & n.a. & 1.58 & 2.48 & 3.54 & 3.71 & 3.07 & 2.82 & 2.16 \\
\hline Other $\ldots \ldots \ldots \ldots \ldots \ldots \ldots \ldots$ & .77 & .61 & .98 & .53 & .57 & .50 & .63 & .91 & 1.51 & 1.54 \\
\hline State and local government & 4.07 & 3.32 & 2.70 & 2.03 & 1.63 & 1.46 & 1.31 & 1.21 & 1.11 & .99 \\
\hline Other $\ldots \ldots \ldots \ldots \ldots \ldots$ & 2.18 & 2.94 & 2.35 & 2.27 & 2.19 & 2.39 & 2.43 & 2.15 & 2.17 & 2.17 \\
\hline Equity $^{2}$ & n.a. & n.a. & .22 & .18 & .22 & .25 & .26 & .32 & .37 & .44 \\
\hline Trading account & .81 & .82 & .83 & .88 & 1.13 & 1.14 & 1.37 & 1.37 & .76 & .80 \\
\hline Gross federal funds sold and reverse RPs & 3.07 & 3.68 & 3.71 & 4.41 & 4.90 & 4.78 & 4.98 & 5.11 & 4.52 & 4.26 \\
\hline Interest-bearing balances at depositories & 6.16 & 6.01 & 5.38 & 4.98 & 4.51 & 4.52 & 4.08 & 3.30 & 2.47 & 2.38 \\
\hline Non-interest-earning assets $\ldots \ldots \ldots \ldots \ldots$ & 13.80 & 12.77 & 13.09 & 13.19 & 13.12 & 12.03 & 11.64 & 11.84 & 11.69 & 12.25 \\
\hline Revaluation gains on off-balance-sheet items ${ }^{3}$ & n.a. & n.a. & n.a. & n.a. & & & n.a. & .57 & .50 & .51 \\
\hline 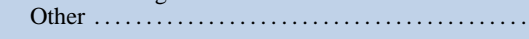 & 13.80 & 12.77 & 13.09 & 13.19 & 13.12 & 12.03 & 11.64 & 11.28 & 11.19 & 11.74 \\
\hline Liabilities & 94.56 & 94.77 & 94.45 & 94.35 & 93.93 & 93.13 & 92.56 & 92.47 & 92.23 & 92.02 \\
\hline Interest-bearing liabilities . & 73.01 & 75.34 & 76.23 & 77.02 & 76.07 & 74.66 & 73.38 & 72.86 & 74.05 & 73.14 \\
\hline Deposits ............. & 52.61 & 55.02 & 56.45 & 57.46 & 59.24 & 56.99 & 54.22 & 53.03 & 52.32 & 51.82 \\
\hline In foreign offices & 10.14 & 9.68 & 8.63 & 7.84 & 6.69 & 6.20 & 6.78 & 8.05 & 8.12 & 7.52 \\
\hline In domestic offices & 42.48 & 45.34 & 47.82 & 49.62 & 52.54 & 50.79 & 47.43 & 44.98 & 44.20 & 44.30 \\
\hline Other checkable deposits & 4.42 & 4.68 & 4.67 & 4.75 & 5.36 & 6.26 & 7.21 & 6.91 & 5.63 & 3.09 \\
\hline Savings (including MMDAs) & 16.02 & 15.67 & 14.58 & 15.50 & 17.62 & 20.21 & 20.60 & 20.13 & 18.78 & 20.73 \\
\hline Small-denomination time deposits & 9.63 & 11.05 & 13.49 & 15.59 & 17.99 & 15.98 & 14.19 & 13.26 & 14.24 & 14.09 \\
\hline Large-denomination time deposits & 12.40 & 13.95 & 15.08 & 13.78 & 11.56 & 8.34 & 5.44 & 4.68 & 5.55 & 6.39 \\
\hline Gross federal funds purchased and RPs & 14.52 & 13.72 & 13.22 & 13.03 & 10.94 & 11.45 & 11.93 & 11.48 & 11.37 & 10.00 \\
\hline Other $\ldots \ldots \ldots \ldots \ldots \ldots \ldots \ldots \ldots \ldots \ldots \ldots \ldots$ & 5.87 & 6.59 & 6.57 & 6.53 & 5.89 & 6.22 & 7.23 & 8.34 & 10.36 & 11.32 \\
\hline Non-interest-bearing liabilities & 21.55 & 19.44 & 18.22 & 17.33 & 17.87 & 18.47 & 19.18 & 19.62 & 18.18 & 18.89 \\
\hline Demand deposits in domestic offices & 16.62 & 15.04 & 13.86 & 13.23 & 13.76 & 14.52 & 15.38 & 15.27 & 14.26 & 14.47 \\
\hline Revaluation losses on off-balance-sheet items ${ }^{3}$. & n.a. & & & & n.a. & & & .53 & .49 & .49 \\
\hline 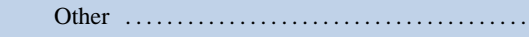 & 4.93 & 4.40 & 4.36 & 4.10 & 4.10 & 3.95 & 3.80 & 3.82 & 3.43 & 3.93 \\
\hline Capital account & 5.44 & 5.23 & 5.55 & 5.65 & 6.07 & 6.87 & 7.44 & 7.53 & 7.77 & 7.98 \\
\hline \multicolumn{11}{|l|}{ Мемо } \\
\hline Commercial real estate loans & n.a. & n.a. & n.a. & n.a. & 11.28 & 10.43 & 9.58 & 8.98 & 8.65 & 8.49 \\
\hline Other real estate owned . & .22 & .31 & .30 & .46 & .76 & .70 & .47 & .25 & .13 & .08 \\
\hline Managed liabilities & 43.29 & 44.27 & 43.81 & 41.50 & 35.42 & 32.53 & 31.69 & 32.83 & 35.64 & 35.56 \\
\hline \multicolumn{11}{|l|}{ Average net consolidated assets } \\
\hline (billions of dollars) $\ldots \ldots \ldots$ & 802 & 870 & 940 & 995 & 66 & 1,003 & 1,082 & 1,204 & 1,338 & 1,450 \\
\hline
\end{tabular}




\section{A.2.-Continued}

C. Banks ranked 11th through 100th by assets

\begin{tabular}{|c|c|c|c|c|c|c|c|c|c|c|}
\hline Item & 1987 & 1988 & 1989 & 1990 & 1991 & 1992 & 1993 & 1994 & 1995 & 1996 \\
\hline & \multicolumn{10}{|c|}{ Effective interest rate (percent) ${ }^{4}$} \\
\hline \multicolumn{11}{|l|}{ Rates earned } \\
\hline Interest-earning assets & 9.19 & 9.87 & 11.10 & 10.41 & 9.22 & 8.01 & 7.37 & 7.29 & 8.31 & 8.26 \\
\hline Taxable equivalent & 9.40 & 10.07 & 11.27 & 10.50 & 9.32 & 8.11 & 7.46 & 7.37 & 8.37 & 8.33 \\
\hline Loans and leases, gross & 9.78 & 10.48 & 11.74 & 11.04 & 9.87 & 8.77 & 8.26 & 8.22 & 9.11 & 9.04 \\
\hline Net of loss provisions & 7.33 & 9.19 & 9.87 & 9.03 & 7.89 & 7.47 & 7.47 & 7.68 & 8.50 & 8.18 \\
\hline Securities $\ldots \ldots \ldots \ldots \ldots$. & 7.87 & 8.21 & 8.76 & 8.81 & 8.16 & 7.08 & 6.06 & 5.70 & 6.38 & 6.49 \\
\hline Taxable equivalent & 8.67 & 8.92 & 9.36 & 9.12 & 8.49 & 7.38 & 6.34 & 5.92 & 6.57 & 6.73 \\
\hline Investment account. & 7.93 & 8.24 & 8.77 & 8.87 & 8.28 & 7.21 & 6.16 & 5.70 & 6.34 & 6.48 \\
\hline U.S. government and other debt & 8.25 & 8.51 & 9.06 & 9.13 & 8.42 & 7.25 & 6.16 & 5.69 & 6.38 & 6.57 \\
\hline State and local .............. & 7.09 & 7.29 & 7.41 & 7.22 & 7.23 & 6.81 & 6.32 & 6.04 & 6.06 & 5.90 \\
\hline Equity $^{2} \ldots \ldots \ldots \ldots \ldots$ & n.a. & n.a. & 9.19 & 8.09 & 7.32 & 6.75 & 5.23 & 5.00 & 5.68 & 4.86 \\
\hline Trading account & 6.99 & 7.68 & 8.66 & 8.01 & 6.46 & 4.73 & 4.74 & 5.75 & 7.27 & 6.61 \\
\hline Gross federal funds sold and reverse RPs & 6.59 & 7.61 & 9.35 & 8.11 & 5.76 & 3.71 & 3.11 & 4.31 & 5.91 & 5.31 \\
\hline Interest-bearing balances at depositories . & 7.68 & 8.87 & 11.35 & 9.72 & 8.15 & 6.77 & 6.50 & 4.69 & 6.78 & 5.86 \\
\hline \multicolumn{11}{|l|}{ Rates paid } \\
\hline Interest-bearing liabilities & 6.75 & 7.34 & 8.66 & 7.93 & 6.34 & 4.45 & 3.76 & 3.72 & 4.94 & 4.75 \\
\hline Interest-bearing deposits & 5.91 & 6.44 & 7.51 & 6.95 & 5.69 & 3.90 & 3.11 & 2.88 & 3.93 & 3.95 \\
\hline In foreign offices .... & 7.78 & 8.92 & 11.08 & 10.08 & 8.38 & 7.26 & 7.37 & 4.60 & 6.30 & 5.34 \\
\hline In domestic offices . & 5.51 & 5.97 & 6.93 & 6.50 & 5.39 & 3.56 & 2.61 & 2.64 & 3.57 & 3.73 \\
\hline Other checkable deposits & 4.44 & 4.53 & 4.57 & 4.64 & 4.16 & 2.45 & 1.70 & 1.62 & 1.89 & 1.81 \\
\hline Savings (including MMDAs) & 5.27 & 5.63 & 6.42 & 6.03 & 4.98 & 3.08 & 2.33 & 2.46 & 3.11 & 2.93 \\
\hline Large-denomination CDs ... & 7.02 & 7.65 & 8.75 & 8.09 & 6.72 & 5.13 & 4.31 & 4.21 & 5.70 & 5.54 \\
\hline Other time deposits ...... & 7.07 & 7.56 & 8.72 & 8.02 & 6.81 & 5.11 & 4.07 & 4.18 & 5.35 & 5.30 \\
\hline \multirow[t]{2}{*}{ Gross federal funds purchased and RPs } & 6.63 & 7.50 & 9.35 & 8.11 & 5.68 & 3.57 & 3.04 & 4.28 & 5.86 & 5.27 \\
\hline & \multicolumn{10}{|c|}{ Income and expense as a percentage of average net consolidated assets } \\
\hline Gross interest income & 8.05 & 8.72 & 9.77 & 9.26 & 8.17 & 7.15 & 6.59 & 6.46 & 7.40 & 7.33 \\
\hline Taxable equivalent & 8.23 & 8.90 & 9.91 & 9.34 & 8.24 & 7.22 & 6.65 & 6.51 & 7.46 & 7.37 \\
\hline Loans .............. & 6.19 & 6.69 & 7.51 & 6.97 & 6.09 & 5.24 & 4.85 & 4.91 & 5.79 & 5.88 \\
\hline Securities & 1.14 & 1.21 & 1.26 & 1.36 & 1.35 & 1.39 & 1.27 & 1.13 & 1.13 & 1.04 \\
\hline Gross federal funds sold and reverse RPs & .20 & .25 & .36 & .37 & .28 & .19 & .15 & .21 & .27 & .23 \\
\hline Other $\ldots \ldots \ldots \ldots \ldots \ldots \ldots \ldots \ldots \ldots \ldots$ & .51 & .57 & .65 & .56 & .45 & .34 & .32 & .21 & .21 & .18 \\
\hline Gross interest expense & 4.85 & 5.45 & 6.50 & 6.06 & 4.75 & 3.28 & 2.74 & 2.67 & 3.62 & 3.43 \\
\hline Deposits ............. & 3.41 & 3.86 & 4.59 & 4.34 & 3.70 & 2.49 & 1.94 & 1.73 & 2.29 & 2.20 \\
\hline Gross federal funds purchased and RPs & .96 & 1.03 & 1.24 & 1.12 & .67 & .43 & .38 & .51 & .67 & .55 \\
\hline 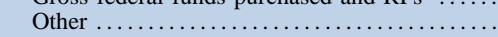 & .48 & .56 & .66 & .60 & .38 & .35 & .43 & .43 & .66 & .68 \\
\hline Net interest income & 3.19 & 3.27 & 3.28 & 3.21 & 3.42 & 3.87 & 3.85 & 3.79 & 3.79 & 3.90 \\
\hline Taxable equivalent & 3.38 & 3.45 & 3.41 & 3.29 & 3.49 & 3.94 & 3.91 & 3.85 & 3.84 & 3.94 \\
\hline Loss provisioning 5 & 1.55 & .82 & 1.20 & 1.27 & 1.23 & .78 & .47 & .32 & .39 & .56 \\
\hline Noninterest income & 1.53 & 1.62 & 1.86 & 1.84 & 2.01 & 2.25 & 2.29 & 2.25 & 2.38 & 2.63 \\
\hline Service charges on deposits & .29 & .30 & .31 & .34 & .40 & .45 & .46 & .45 & .44 & .44 \\
\hline Income from fiduciary activities & .36 & .35 & .35 & .33 & .35 & .38 & .38 & .39 & .40 & .43 \\
\hline Trading income........... & .07 & .07 & .08 & .08 & .10 & .09 & .14 & .08 & .09 & .08 \\
\hline Other $\ldots \ldots \ldots \ldots \ldots \ldots \ldots$ & .81 & .89 & 1.12 & 1.08 & 1.16 & 1.33 & 1.32 & 1.33 & 1.45 & 1.69 \\
\hline Noninterest expense & 3.23 & 3.29 & 3.34 & 3.43 & 3.72 & 3.99 & 3.95 & 3.86 & 3.79 & 3.89 \\
\hline Salaries, wages, and employee benefits & 1.48 & 1.48 & 1.47 & 1.46 & 1.51 & 1.54 & 1.52 & 1.50 & 1.47 & 1.52 \\
\hline Expenses of premises and fixed assets & .49 & .50 & .50 & .49 & .50 & .50 & .48 & .47 & .47 & .48 \\
\hline 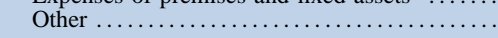 & 1.26 & 1.31 & 1.37 & 1.48 & 1.72 & 1.96 & 1.95 & 1.89 & 1.85 & 1.89 \\
\hline Net noninterest expense & 1.70 & 1.67 & 1.47 & 1.59 & 1.71 & 1.74 & 1.66 & 1.61 & 1.41 & 1.26 \\
\hline Realized gains on investment account securities . & .05 & * & .04 & .03 & .01 & .01 & .14 & .15 & .09 & -.01 \\
\hline Income before taxes and extraordinary items & $*$ & .77 & .65 & .37 & .62 & 1.51 & 1.82 & 1.85 & 2.01 & 2.11 \\
\hline Taxes $\ldots \ldots \ldots \ldots \ldots \ldots$ & .09 & .28 & .18 & .15 & .19 & .49 & .56 & .63 & .70 & .76 \\
\hline Extraordinary items & $*$ & .02 & $*$ & .01 & .03 & .03 & $*$ & $*$ & $*$ & $*$ \\
\hline Net income (return on assets) & -.09 & .51 & .47 & .23 & .47 & 1.05 & 1.26 & 1.22 & 1.31 & 1.35 \\
\hline Cash dividends declared .... & .34 & .41 & .40 & .37 & .47 & .46 & .76 & .86 & .85 & 1.10 \\
\hline Retained income ............ & -.43 & .09 & .06 & -.14 & $* 1$ & .58 & .49 & .36 & .036 & .26 \\
\hline Memo: Return on equity & -1.70 & 9.72 & 8.41 & 4.07 & 7.71 & 15.21 & 16.91 & 16.27 & 16.85 & 16.93 \\
\hline
\end{tabular}

* In absolute value, less than 0.005 percent.

n.a. Not available. MMDA Money market deposit account. RP Repurchase agreement. CD Certificate of deposit.

1. Includes allocated transfer risk reserve.

2. As in the Call Report, equity securities are combined with "other debt securities" before 1989.

3. Before 1994, the netted value of off-balance-sheet items appeared in "trading account securities" if a gain and "other non-interest-bearing liabilities" if a loss.

4. Where possible, based on the average of quarterly balance sheet data reported on schedule RC-K of the quarterly Call Report.

5. Includes provisioning for allocated transfer risk. 
A.2. Portfolio composition, interest rates, and income and expense, all insured domestic commercial banks, 1987-96 D. Banks ranked 101st through 1,000th by assets

\begin{tabular}{|c|c|c|c|c|c|c|c|c|c|c|}
\hline Item & 1987 & 1988 & 1989 & 1990 & 1991 & 1992 & 1993 & 1994 & 1995 & 1996 \\
\hline & \multicolumn{10}{|c|}{ Balance sheet items as a percentage of average net consolidated assets } \\
\hline Interest-earning assets & 88.34 & 88.88 & 88.98 & 88.84 & 88.91 & 89.02 & 89.55 & 90.09 & 90.13 & 90.14 \\
\hline Loans and leases, net & 61.60 & 63.03 & 63.62 & 63.09 & 61.03 & 58.51 & 57.94 & 59.74 & 62.23 & 62.69 \\
\hline Commercial and industrial & 18.12 & 17.83 & 17.68 & 16.69 & 15.05 & 13.33 & 12.19 & 12.07 & 12.68 & 12.76 \\
\hline U.S. addressees ........ & 17.87 & 17.67 & 17.53 & 16.56 & 14.89 & 13.15 & 12.03 & 11.90 & 12.52 & 12.58 \\
\hline Foreign addressees $\ldots$. & .24 & .16 & .15 & .13 & .16 & .18 & .16 & .16 & .16 & .18 \\
\hline Consumer ........... & 15.34 & 15.91 & 15.49 & 15.48 & 15.10 & 14.22 & 14.84 & 15.85 & 16.39 & 16.09 \\
\hline Credit card & 4.65 & 5.21 & 4.83 & 5.22 & 5.71 & $\begin{array}{r}14.22 \\
5.42\end{array}$ & $\begin{array}{r}14.04 \\
5.65\end{array}$ & 6.06 & 6.45 & 6.90 \\
\hline Installment and other & 10.69 & 10.70 & 10.66 & 10.26 & 9.40 & 8.80 & 9.19 & 9.79 & 9.94 & 9.19 \\
\hline Real estate ........... & 22.25 & 24.28 & 25.97 & 27.01 & 27.53 & 28.10 & 28.60 & 29.42 & 30.77 & 31.27 \\
\hline In domestic offices & 22.25 & 24.27 & 25.95 & 26.99 & 27.49 & 28.06 & 28.58 & 29.40 & 30.75 & 31.24 \\
\hline Construction and land development & 4.57 & $\begin{array}{r}24.21 \\
4.73\end{array}$ & 4.82 & 4.37 & 3.67 & $\begin{array}{r}2.00 \\
2.86\end{array}$ & 2.26 & 2.08 & 2.21 & $\begin{array}{r}31.24 \\
2.38\end{array}$ \\
\hline Farmland $\ldots \ldots \ldots \ldots \ldots \ldots \ldots$ & .26 & .27 & .27 & .28 & .28 & .32 & .34 & .36 & .40 & .46 \\
\hline One- to four-family residential & 9.48 & 10.64 & 11.56 & 12.49 & 13.23 & 14.25 & 15.17 & 16.25 & 17.47 & 17.28 \\
\hline Home equity $\ldots \ldots \ldots \ldots \ldots$ & n.a. & 1.73 & 2.08 & 2.31 & 2.53 & 2.56 & 2.50 & 2.33 & 2.36 & 2.30 \\
\hline Other ........ & n.a. & 8.91 & 9.48 & 10.18 & 10.70 & 11.69 & 12.66 & 13.92 & 15.11 & 14.98 \\
\hline Multifamily residential & .68 & .67 & $\begin{array}{r}.70 \\
.70\end{array}$ & .73 & .80 & .95 & 1.07 & 1.13 & 1.21 & 1.28 \\
\hline Nonfarm nonresidential & $\begin{array}{l}.00 \\
7.26\end{array}$ & 7.97 & 8.61 & 9.11 & 9.50 & 9.68 & 9.74 & 9.57 & 9.47 & 9.84 \\
\hline In foreign offices $\ldots \ldots \ldots$ & .01 & 01 & .01 & 03 & .05 & .04 & .02 & .03 & 02 & 02 \\
\hline Depository institutions & 1.13 & 1.01 & .92 & 1.05 & .93 & .80 & .43 & .39 & .35 & .48 \\
\hline Foreign governments & .25 & .20 & .16 & .09 & .07 & .05 & .03 & .02 & .02 & .02 \\
\hline Agricultural production & .48 & .47 & .45 & .47 & .49 & .54 & .56 & .62 & .69 & .70 \\
\hline Other loans ............ & 4.94 & 4.23 & 3.77 & 3.16 & 2.81 & 2.47 & 2.16 & 2.00 & 1.80 & 1.69 \\
\hline Lease-financing receivables & .72 & .78 & .82 & .83 & .85 & .78 & .77 & .82 & .90 & 1.00 \\
\hline LESS: Unearned income on loans & -61 & -60 & -.56 & -.00 & -.40 & -30 & -.21 & -.15 & -12 & -10 \\
\hline LEss: Loss reserves $^{1} \ldots \ldots \ldots \ldots$ & -1.01 & -1.07 & -1.07 & -1.20 & -1.42 & -1.49 & -1.44 & -1.30 & -1.23 & -1.23 \\
\hline Securities ............ & 18.72 & 18.52 & 18.75 & 19.34 & 21.28 & 24.12 & 25.92 & 25.71 & 23.06 & 22.64 \\
\hline Investment account & 18.50 & 18.25 & 18.38 & 18.87 & 20.92 & 23.77 & 25.63 & 25.39 & 22.86 & 22.51 \\
\hline Debt .............. & 18.50 & 18.25 & 18.02 & 18.54 & 20.55 & 23.31 & 25.15 & 24.95 & 22.39 & 21.99 \\
\hline U.S. Treasury & $\begin{array}{r}18.50 \\
7.14\end{array}$ & $\begin{array}{r}18.25 \\
6.52\end{array}$ & $\begin{array}{r}18.02 \\
5.91\end{array}$ & $\begin{array}{r}10.54 \\
5.44\end{array}$ & $\begin{array}{r}20.33 \\
6.16\end{array}$ & $\begin{array}{r}23.31 \\
7.75\end{array}$ & 8.63 & $\begin{array}{r}24.93 \\
8.26\end{array}$ & $\begin{array}{r}22.39 \\
6.47\end{array}$ & $\begin{array}{r}21.99 \\
5.59\end{array}$ \\
\hline \multicolumn{11}{|l|}{ U.S. government agency and } \\
\hline corporation obligations & 4.06 & 4.81 & 6.07 & 7.75 & 9.35 & 11.07 & 12.32 & 12.67 & 12.21 & 12.62 \\
\hline Government-backed mortgage pools & 1.89 & 2.33 & 3.03 & 3.83 & 4.51 & 4.74 & 4.97 & 5.57 & 5.42 & 5.67 \\
\hline Collateralized mortgage obligations & $\begin{array}{l}\text { n.a. } \\
\text { n.a. }\end{array}$ & n.a. & n.a. & 1.74 & 2.74 & 3.95 & 4.82 & 4.39 & 3.55 & 3.11 \\
\hline Other $\ldots \ldots \ldots \ldots \ldots \ldots \ldots \ldots \ldots \ldots$ & 2.17 & 2.48 & 3.04 & 2.17 & 2.11 & 2.38 & 2.53 & 2.71 & 3.25 & 3.84 \\
\hline State and local government & 5.03 & 4.10 & 3.50 & 3.11 & 2.65 & 2.27 & 2.26 & 2.29 & 2.13 & 2.23 \\
\hline Other $\ldots \ldots \ldots \ldots \ldots \ldots$. & 2.26 & 2.82 & 2.55 & 2.25 & 2.38 & 2.22 & $\begin{array}{l}2.20 \\
1.94\end{array}$ & 1.74 & $\begin{array}{l}2.15 \\
1.58\end{array}$ & 1.55 \\
\hline Equity $^{2}$ & n.a. & n.a. & .35 & .32 & .37 & .46 & .47 & .44 & .47 & .52 \\
\hline Trading account & .22 & .28 & .38 & .48 & .37 & .35 & .29 & .32 & .20 & .13 \\
\hline Gross federal funds sold and reverse RPs & 4.94 & 4.45 & 4.11 & 4.51 & 4.71 & 4.92 & 4.48 & 3.64 & 3.91 & 3.86 \\
\hline Interest-bearing balances at depositories . & 3.08 & 2.87 & 2.49 & 1.90 & 1.90 & 1.47 & 1.20 & 1.00 & 93 & .96 \\
\hline Non-interest-earning assets $\ldots \ldots \ldots \ldots \ldots \ldots$ & 11.66 & 11.12 & 11.02 & 11.16 & 11.09 & 10.98 & 10.45 & 9.91 & 9.87 & 9.86 \\
\hline Revaluation gains on off-balance-sheet items $\mathrm{s}^{3}$ & $\begin{array}{l}11.00 \\
\text { n.a. }\end{array}$ & $\begin{array}{l}11.12 \\
\text { n.a. }\end{array}$ & $\begin{array}{l}11.02 \\
\text { n.a. }\end{array}$ & $\begin{array}{l}11.10 \\
\text { n.a. }\end{array}$ & n.a. & $\begin{array}{l}10.90 \\
\text { n.a. }\end{array}$ & $\begin{array}{l}10.4 J \\
\text { n.a. }\end{array}$ & $\begin{array}{r}9.91 \\
.02\end{array}$ & $\begin{array}{r}9.01 \\
.05\end{array}$ & $\begin{array}{r}9.00 \\
.02\end{array}$ \\
\hline 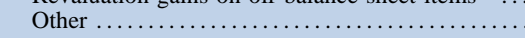 & 11.66 & 11.12 & 11.02 & 11.16 & 11.09 & 10.98 & 10.45 & 9.90 & 9.83 & 9.83 \\
\hline Liabilities & 93.28 & 93.34 & 93.28 & 93.07 & 92.89 & 92.47 & 91.85 & 91.62 & 91.36 & 91.06 \\
\hline Interest-bearing liabilities & 73.92 & 75.59 & 76.42 & 77.04 & 77.25 & 75.98 & 74.42 & 74.77 & 75.02 & 75.09 \\
\hline Deposits ............ & 62.43 & 63.00 & 63.74 & 65.05 & 66.33 & 65.62 & 63.04 & 60.38 & 59.59 & 59.82 \\
\hline In foreign offices & 1.96 & 2.04 & $\begin{array}{r}0.14 \\
2.09\end{array}$ & 1.65 & 1.76 & $\begin{array}{l}0.02 \\
1.56\end{array}$ & 1.43 & $\begin{array}{r}0.50 \\
1.69\end{array}$ & 1.71 & 1.33 \\
\hline In domestic offices & 60.47 & 60.97 & 61.65 & 63.40 & 64.58 & 64.06 & 61.61 & 58.69 & 57.88 & 58.49 \\
\hline Other checkable deposits & 7.27 & 7.39 & 7.14 & 7.31 & 7.83 & 9.14 & 9.94 & 9.70 & 8.53 & 6.20 \\
\hline Savings (including MMDAs) & 22.83 & 21.27 & 19.52 & 19.69 & 20.79 & 23.33 & 24.05 & 22.92 & 20.72 & 22.43 \\
\hline Small-denomination time deposits & $\begin{array}{l}22.03 \\
17.75\end{array}$ & 19.34 & 22.08 & 24.09 & 25.23 & 23.55 & 20.77 & 19.29 & 21.08 & 21.55 \\
\hline Large-denomination time deposits ... & 12.62 & 12.96 & 12.91 & 12.31 & 10.73 & 8.06 & 6.84 & 6.78 & 7.54 & 8.31 \\
\hline Gross federal funds purchased and RPs . & 8.46 & 8.63 & 9.21 & 8.43 & 7.46 & $\begin{array}{l}0.00 \\
7.17\end{array}$ & 7.43 & 8.45 & 8.30 & 8.17 \\
\hline Other $\ldots \ldots \ldots \ldots \ldots \ldots \ldots \ldots \ldots \ldots \ldots \ldots \ldots$ & $\begin{array}{l}0.40 \\
3.03\end{array}$ & 3.96 & 3.47 & $\begin{array}{l}0.43 \\
3.56\end{array}$ & 3.45 & 3.19 & 3.94 & $\begin{array}{l}0.45 \\
5.94\end{array}$ & 7.14 & $\begin{array}{l}0.17 \\
7.10\end{array}$ \\
\hline Non-interest-bearing liabilities & 19.36 & 17.74 & 16.85 & 16.03 & 15.64 & 16.49 & 17.43 & 16.85 & 16.34 & 15.97 \\
\hline Demand deposits in domestic offices .......... & 17.35 & 15.84 & 14.86 & 14.07 & 13.57 & 14.39 & 15.07 & 14.58 & 14.05 & 13.81 \\
\hline Revaluation losses on off-balance-sheet items ${ }^{3}$ & n.a. & $\begin{array}{l}15.04 \\
\text { n.a. }\end{array}$ & n.a. & n.a. & n.a. & n.a. & n.a. & .02 & .05 & $\begin{array}{r}15.01 \\
.02\end{array}$ \\
\hline 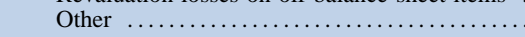 & 2.00 & 1.90 & 1.99 & 1.96 & 2.07 & 2.10 & 2.36 & 2.25 & 2.24 & 2.14 \\
\hline Capital account & 6.72 & 6.66 & 6.72 & 6.93 & 7.11 & 7.53 & 8.15 & 8.38 & 8.64 & 8.94 \\
\hline \multicolumn{11}{|l|}{ Мемо } \\
\hline Commercial real estate loans & n.a. & n.a. & n.a. & n.a. & 13.84 & 12.95 & 12.30 & 11.92 & 11.97 & 12.51 \\
\hline Other real estate owned ..... & .37 & .42 & .43 & .52 & .77 & .80 & .57 & .28 & .17 & .13 \\
\hline Managed liabilities ........... & 26.00 & 27.51 & 27.62 & 25.93 & 23.40 & 19.97 & 19.65 & 22.86 & 24.69 & 24.92 \\
\hline $\begin{array}{l}\text { Average net consolidated assets } \\
\text { (billions of dollars) } \ldots . . . \text {. }\end{array}$ & 771 & 839 & 892 & 937 & 961 & 968 & 977 & 1.032 & 1.094 & 1.078 \\
\hline
\end{tabular}




\section{A.2.-Continued}

D. Banks ranked 101st through 1,000th by assets

\begin{tabular}{|c|c|c|c|c|c|c|c|c|c|c|}
\hline Item & 1987 & 1988 & 1989 & 1990 & 1991 & 1992 & 1993 & 1994 & 1995 & 1996 \\
\hline & \multicolumn{10}{|c|}{ Effective interest rate (percent) ${ }^{4}$} \\
\hline \multicolumn{11}{|l|}{ Rates earned } \\
\hline Interest-earning assets & 9.47 & 9.92 & 10.75 & 10.44 & 9.54 & 8.17 & 7.44 & 7.61 & 8.45 & 8.44 \\
\hline Taxable equivalent & 9.82 & 10.16 & 10.96 & 10.60 & 9.68 & 8.29 & 7.56 & 7.70 & 8.54 & 8.53 \\
\hline Loans and leases, gross & 10.33 & 10.77 & 11.62 & 11.24 & 10.41 & 9.15 & 8.58 & 8.67 & 9.49 & 9.47 \\
\hline Net of loss provisions & 9.05 & 9.62 & 10.45 & 9.50 & 8.70 & 7.87 & 7.77 & 8.13 & 8.80 & 8.65 \\
\hline Securities $\ldots \ldots \ldots \ldots \ldots$. & 7.68 & 7.84 & 8.34 & 8.54 & 8.10 & 6.91 & 5.79 & 5.71 & 6.25 & 6.32 \\
\hline Taxable equivalent & 8.76 & 8.58 & 8.98 & 9.02 & 8.53 & 7.22 & 6.11 & 5.96 & 6.51 & 6.60 \\
\hline Investment account. & 7.71 & 7.85 & 8.36 & 8.51 & 8.12 & 6.93 & 5.80 & 5.72 & 6.25 & 6.32 \\
\hline U.S. government and other debt & 7.96 & 8.05 & 8.62 & 8.77 & 8.29 & 6.97 & 5.77 & 5.70 & 6.30 & 6.42 \\
\hline State and local .............. & 7.03 & 7.17 & 7.28 & 7.34 & 7.25 & 6.87 & 6.30 & 5.94 & 5.83 & 5.50 \\
\hline Equity $^{2} \ldots \ldots \ldots \ldots \ldots$ & n.a. & n.a. & 6.90 & 6.94 & 6.02 & 5.06 & 4.95 & 5.34 & 6.06 & 6.33 \\
\hline Trading account & 5.80 & 6.96 & 7.61 & 9.92 & 6.86 & 5.62 & 4.82 & 5.29 & 5.55 & 5.69 \\
\hline Gross federal funds sold and reverse RPs & 6.64 & 7.47 & 9.05 & 7.98 & 5.63 & 3.49 & 3.02 & 4.07 & 5.45 & 5.26 \\
\hline Interest-bearing balances at depositories . & 7.04 & 7.82 & 9.21 & 8.52 & 6.82 & 4.61 & 3.50 & 4.25 & 6.09 & 5.55 \\
\hline \multicolumn{11}{|l|}{ Rates paid } \\
\hline Interest-bearing liabilities & 6.31 & 6.72 & 7.73 & 7.28 & 6.09 & 4.21 & 3.33 & 3.58 & 4.65 & 4.59 \\
\hline Interest-bearing deposits & 5.46 & 5.82 & 6.63 & 6.36 & 5.42 & 3.67 & 2.82 & 2.86 & 3.73 & 3.87 \\
\hline In foreign offices .... & 6.77 & 7.65 & 8.98 & 8.12 & 6.38 & 4.25 & 3.35 & 4.31 & 5.93 & 5.42 \\
\hline In domestic offices . & 5.43 & 5.77 & 6.56 & 6.32 & 5.39 & 3.66 & 2.81 & 2.83 & 3.67 & 3.84 \\
\hline Other checkable deposits & 4.65 & 4.77 & 4.88 & 4.77 & 4.28 & 2.68 & 2.02 & 1.87 & 2.03 & 1.97 \\
\hline Savings (including MMDAs) & 5.29 & 5.54 & 6.13 & 5.99 & 5.13 & 3.35 & 2.58 & 2.65 & 3.24 & 3.12 \\
\hline Large-denomination CDs ... & 6.83 & 7.42 & 8.70 & 8.05 & 6.62 & 4.77 & 3.89 & 4.24 & 5.62 & 5.49 \\
\hline Other time deposits ..... & 7.16 & 7.46 & 8.32 & 8.06 & 7.07 & 5.37 & 4.41 & 4.42 & 5.54 & 5.60 \\
\hline \multirow[t]{2}{*}{ Gross federal funds purchased and RPs } & 6.35 & 7.40 & 9.01 & 7.87 & 5.61 & 3.47 & 2.95 & 4.13 & 5.61 & 5.15 \\
\hline & \multicolumn{10}{|c|}{ Income and expense as a percentage of average net consolidated assets } \\
\hline Gross interest income & 8.40 & 8.88 & 9.68 & 9.40 & 8.62 & 7.39 & 6.76 & 6.93 & 7.71 & 7.71 \\
\hline Taxable equivalent & 8.72 & 9.10 & 9.86 & 9.53 & 8.74 & 7.49 & 6.85 & 7.01 & 7.79 & 7.79 \\
\hline Loans .............. & 6.45 & 6.89 & 7.52 & 7.23 & 6.50 & 5.48 & 5.08 & 5.27 & 6.01 & 6.02 \\
\hline Securities & 1.43 & 1.43 & 1.54 & 1.61 & 1.70 & 1.65 & 1.49 & 1.45 & 1.43 & 1.42 \\
\hline Gross federal funds sold and reverse RPs & .31 & .32 & .38 & .36 & .27 & .17 & .14 & .14 & .21 & .20 \\
\hline Other $\ldots \ldots \ldots \ldots \ldots \ldots \ldots \ldots \ldots \ldots \ldots$ & .22 & .24 & .25 & .20 & .15 & .08 & .06 & .06 & .07 & .06 \\
\hline Gross interest expense & 4.59 & 5.03 & 5.84 & 5.55 & 4.67 & 3.17 & 2.47 & 2.66 & 3.47 & 3.42 \\
\hline Deposits . ............ & 3.82 & 4.10 & 4.70 & 4.59 & 4.02 & 2.75 & 2.07 & 2.02 & 2.56 & 2.57 \\
\hline Gross federal funds purchased and RPs & .53 & .64 & .83 & .67 & .42 & .25 & .22 & .35 & .46 & .42 \\
\hline 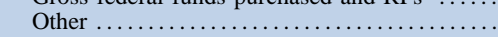 & .23 & .29 & .31 & .29 & .23 & .17 & .17 & .29 & .45 & .42 \\
\hline Net interest income & 3.81 & 3.85 & 3.84 & 3.84 & 3.95 & 4.21 & 4.29 & 4.27 & 4.25 & 4.30 \\
\hline Taxable equivalent & 4.13 & 4.07 & 4.02 & 3.98 & 4.07 & 4.32 & 4.39 & 4.36 & 4.33 & 4.37 \\
\hline Loss provisioning 5 & .80 & .74 & .75 & 1.12 & 1.07 & .77 & .48 & .33 & .43 & .52 \\
\hline Noninterest income & 1.36 & 1.36 & 1.38 & 1.50 & 1.64 & 1.70 & 1.84 & 1.86 & 1.84 & 1.87 \\
\hline Service charges on deposits & .34 & .35 & .36 & .37 & .40 & .44 & .45 & .42 & .42 & .41 \\
\hline Income from fiduciary activities & .25 & .25 & .25 & .26 & .27 & .28 & .29 & .28 & .27 & .28 \\
\hline Trading income........... & .03 & .03 & .04 & .02 & .04 & .02 & .03 & .02 & .03 & .02 \\
\hline Other $\ldots \ldots \ldots \ldots \ldots \ldots \ldots \ldots$ & .73 & .74 & .74 & .84 & .94 & .95 & 1.08 & 1.14 & 1.12 & 1.16 \\
\hline Noninterest expense & 3.54 & 3.50 & 3.45 & 3.51 & 3.75 & 3.89 & 3.93 & 3.79 & 3.69 & 3.69 \\
\hline Salaries, wages, and employee benefits & 1.54 & 1.49 & 1.48 & 1.47 & 1.48 & 1.51 & 1.52 & 1.49 & 1.44 & 1.44 \\
\hline Expenses of premises and fixed assets & .52 & .50 & .49 & .49 & .49 & .50 & .48 & .47 & .45 & .45 \\
\hline 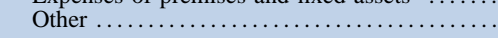 & 1.47 & 1.51 & 1.49 & 1.55 & 1.79 & 1.88 & 1.93 & 1.83 & 1.79 & 1.80 \\
\hline Net noninterest expense & 2.18 & 2.14 & 2.07 & 2.01 & 2.11 & 2.19 & 2.09 & 1.93 & 1.85 & 1.82 \\
\hline Realized gains on investment account securities . & .04 & $*$ & .01 & .01 & .09 & .10 & .06 & -.05 & -.01 & .02 \\
\hline Income before taxes and extraordinary items & .88 & .98 & 1.02 & .72 & .86 & 1.35 & 1.79 & 1.97 & 1.96 & 1.98 \\
\hline Taxes $\ldots \ldots \ldots \ldots \ldots \ldots \ldots$ & .27 & .32 & .32 & .22 & .29 & .44 & .61 & .67 & .68 & .69 \\
\hline Extraordinary items & .02 & .01 & $*$ & $*$ & .03 & $*$ & .04 & $*$ & $*$ & $*$ \\
\hline Net income (return on assets) & .62 & .67 & .71 & .51 & .60 & .92 & 1.22 & 1.29 & 1.28 & 1.29 \\
\hline Cash dividends declared .... & .44 & .48 & .48 & .53 & .58 & .48 & .79 & .81 & $\begin{array}{r}1.20 \\
.87\end{array}$ & 1.04 \\
\hline Retained income $\ldots . . . .$. & .18 & .18 & .23 & -.02 & .02 & .43 & .43 & .48 & .41 & .25 \\
\hline Memo: Return on equity & 9.25 & 10.01 & 10.54 & 7.41 & 8.45 & 12.16 & 14.94 & 15.45 & 14.86 & 14.42 \\
\hline
\end{tabular}

* In absolute value, less than 0.005 percent.

n.a. Not available. MMDA Money market deposit account. RP Repurchase agreement. CD Certificate of deposit.

1. Includes allocated transfer risk reserve.

2. As in the Call Report, equity securities are combined with "other debt securities" before 1989 .

3. Before 1994, the netted value of off-balance-sheet items appeared in "trading account securities" if a gain and "other non-interest-bearing liabilities" if a loss.

4. Where possible, based on the average of quarterly balance sheet data reported on schedule RC-K of the quarterly Call Report.

5. Includes provisioning for allocated transfer risk. 
A.2. Portfolio composition, interest rates, and income and expense, all insured domestic commercial banks, 1987-96 E. Banks not ranked among the 1,000 largest by assets

\begin{tabular}{|c|c|c|c|c|c|c|c|c|c|c|}
\hline Item & 1987 & 1988 & 1989 & 1990 & 1991 & 1992 & 1993 & 1994 & 1995 & 1996 \\
\hline & \multicolumn{10}{|c|}{ Balance sheet items as a percentage of average net consolidated assets } \\
\hline Interest-earning assets & 90.51 & 90.81 & 90.90 & 91.06 & 91.24 & 91.39 & 91.65 & 91.72 & 91.70 & 91.64 \\
\hline Loans and leases, net & 52.82 & 53.88 & 54.84 & 54.74 & 54.05 & 53.03 & 52.94 & 54.64 & 56.60 & 57.38 \\
\hline Commercial and industrial & 12.84 & 12.34 & 12.10 & 11.53 & 10.59 & 9.74 & 9.24 & 9.31 & 9.66 & 9.97 \\
\hline U.S. addressees $\ldots . \ldots \ldots$ & 12.81 & 12.32 & 12.07 & 11.49 & 10.55 & 9.70 & 9.20 & 9.27 & 9.59 & 9.90 \\
\hline Foreign addressees ... & .03 & .02 & .03 & .04 & .04 & .04 & .04 & .05 & .06 & .07 \\
\hline Consumer $\ldots \ldots \ldots \ldots$ & 11.74 & 11.48 & 11.46 & 11.20 & 10.49 & 9.68 & 9.17 & 9.38 & 9.54 & 9.41 \\
\hline Credit card & .80 & .86 & .93 & 1.00 & 1.08 & 1.00 & .92 & .96 & 1.01 & 1.03 \\
\hline Installment and other & 10.94 & 10.62 & 10.53 & 10.20 & 9.41 & 8.68 & 8.25 & 8.41 & 8.53 & 8.38 \\
\hline Real estate ........... & 24.07 & 26.02 & 27.36 & 28.35 & 29.31 & 30.15 & 31.10 & 32.19 & 33.55 & 34.11 \\
\hline In domestic offices & 24.07 & 26.02 & 27.36 & 28.35 & 29.31 & 30.15 & 31.09 & 32.18 & 33.54 & 34.10 \\
\hline Construction and land development & 2.19 & 2.22 & 2.29 & 2.37 & 2.18 & 1.98 & 1.93 & 2.14 & 2.38 & 2.61 \\
\hline Farmland..$\ldots \ldots \ldots \ldots \ldots \ldots$ & 1.59 & 1.74 & 1.82 & 1.86 & 1.93 & 2.06 & 2.20 & 2.34 & 2.48 & 2.55 \\
\hline One- to four-family residential & 12.80 & 14.06 & 14.81 & 15.37 & 15.99 & 16.44 & 16.82 & 16.94 & 17.45 & 17.48 \\
\hline Home equity $\ldots \ldots \ldots \ldots \ldots$ & n.a. & .73 & .94 & 1.16 & 1.29 & 1.34 & 1.27 & 1.21 & 1.20 & 1.19 \\
\hline Other & n.a. & 13.32 & 13.86 & 14.21 & 14.69 & 15.10 & 15.55 & 15.73 & 16.25 & 16.29 \\
\hline Multifamily residential & .60 & .61 & .62 & .66 & .71 & .77 & .84 & .93 & .95 & .92 \\
\hline Nonfarm nonresidential & 6.90 & 7.40 & 7.82 & 8.09 & 8.49 & 8.91 & 9.30 & 9.83 & 10.27 & 10.54 \\
\hline In foreign offices $\ldots \ldots \ldots$. & $*$ & $*$ & * & $*$ & $*$ & $*$ & $*$ & * & * & $*$ \\
\hline Depository institutions & .30 & .31 & .26 & .23 & .20 & .13 & .12 & .13 & .16 & .17 \\
\hline Foreign governments & .01 & .02 & .01 & .01 & .01 & .01 & .02 & .01 & $*$ & $*$ \\
\hline Agricultural production & 3.30 & 3.25 & 3.28 & 3.30 & 3.48 & 3.54 & 3.58 & 3.89 & 3.95 & 3.92 \\
\hline Other loans ............ & 1.90 & 1.75 & 1.67 & 1.41 & 1.24 & .99 & .87 & .81 & .76 & .73 \\
\hline Lease-financing receivables & .19 & .19 & .19 & .18 & .17 & .17 & .18 & .20 & .22 & .23 \\
\hline LESS: Unearned income on loans & -.67 & -.61 & -.60 & -.58 & -.51 & -.43 & -.36 & -.31 & -.30 & -.27 \\
\hline LESS: Loss reserves ${ }^{1} \ldots \ldots \ldots \ldots$ & -.86 & -.88 & -.88 & -.89 & -.93 & -.96 & -.97 & -.95 & -.93 & -.90 \\
\hline Securities...$\ldots \ldots \ldots$ & 27.67 & 27.98 & 27.92 & 28.38 & 29.98 & 32.10 & 33.06 & 32.90 & 30.51 & 29.53 \\
\hline Investment account & 27.59 & 27.93 & 27.85 & 28.28 & 29.92 & 32.04 & 33.00 & 32.86 & 30.47 & 29.50 \\
\hline Debt $\ldots \ldots \ldots \ldots$ & 27.59 & 27.93 & 27.45 & 27.92 & 29.55 & 31.60 & 32.55 & 32.42 & 30.02 & 29.01 \\
\hline U.S. Treasury $\ldots \ldots \ldots \ldots$ & 10.64 & 9.75 & 8.84 & 8.77 & 9.24 & 10.25 & 10.48 & 10.81 & 9.19 & 7.85 \\
\hline \multicolumn{11}{|l|}{ U.S. government agency and } \\
\hline Government-backed mortgage pools & $\begin{array}{l}8.18 \\
2.66\end{array}$ & $\begin{array}{l}9.80 \\
3.22\end{array}$ & $\begin{array}{r}11.31 \\
3.76\end{array}$ & $\begin{array}{r}12.43 \\
4.58\end{array}$ & $\begin{array}{r}13.81 \\
5.59\end{array}$ & $\begin{array}{r}15.04 \\
5.52\end{array}$ & $\begin{array}{r}15.80 \\
5.38\end{array}$ & $\begin{array}{r}15.35 \\
4.81\end{array}$ & $\begin{array}{r}15.13 \\
4.19\end{array}$ & $\begin{array}{r}15.6 / \\
4.21\end{array}$ \\
\hline Collateralized mortgage obligations . & n.a. & n.a. & n.a. & .92 & 1.55 & 2.66 & 3.33 & 3.11 & 2.76 & 2.46 \\
\hline Other $\ldots \ldots \ldots \ldots \ldots \ldots$ & 5.52 & 6.58 & 7.61 & 6.94 & 6.67 & 6.85 & 7.09 & 7.43 & 8.18 & 9.00 \\
\hline State and local government & 6.63 & 5.65 & 4.94 & 4.56 & 4.26 & 4.29 & 4.70 & 5.01 & 4.69 & 4.62 \\
\hline Other $\ldots \ldots \ldots \ldots \ldots \ldots$ & 2.13 & 2.72 & 2.30 & 2.15 & 2.23 & 2.03 & 1.57 & 1.25 & 1.01 & .86 \\
\hline Equity $^{2}$ & n.a. & n.a. & .40 & .36 & .38 & .44 & .45 & .44 & .45 & .49 \\
\hline Trading account & .08 & .05 & .07 & .10 & .06 & .05 & .07 & .04 & .03 & .03 \\
\hline Gross federal funds sold and reverse RPs & 6.66 & 5.76 & 5.74 & 6.13 & 5.64 & 5.10 & 4.68 & 3.42 & 3.92 & 4.04 \\
\hline Interest-bearing balances at depositories & 3.36 & 3.19 & 2.40 & 1.81 & 1.57 & 1.16 & .97 & .76 & .67 & .69 \\
\hline Non-interest-earning assets $\ldots \ldots \ldots \ldots \ldots$ & 9.49 & 9.19 & 9.10 & 8.94 & 8.76 & 8.61 & 8.35 & 8.28 & 8.30 & 8.36 \\
\hline Revaluation gains on off-balance-sheet items ${ }^{3}$ & n.a. & n.a. & n.a. & n.a. & n.a. & n.a. & n.a. & $*$ & $*$ & * \\
\hline Other $\ldots \ldots \ldots \ldots \ldots \ldots \ldots \ldots \ldots \ldots \ldots \ldots \ldots \ldots$ & 9.49 & 9.19 & 9.10 & 8.94 & 8.76 & 8.61 & 8.35 & 8.28 & 8.30 & 8.36 \\
\hline Liabilities & 91.74 & 91.61 & 91.44 & 91.40 & 91.38 & 91.07 & 90.63 & 90.43 & 90.03 & 89.81 \\
\hline Interest-bearing liabilities & 76.39 & 76.94 & 77.13 & 77.83 & 78.40 & 77.83 & 76.88 & 76.19 & 75.74 & 75.58 \\
\hline Deposits ............ & 74.39 & 74.84 & 75.00 & 75.79 & 76.41 & 75.75 & 74.54 & 73.14 & 72.70 & 72.47 \\
\hline In foreign offices & .04 & .04 & .06 & .07 & .08 & .07 & .08 & .09 & .11 & .10 \\
\hline In domestic offices & 74.35 & 74.81 & 74.93 & 75.72 & 76.34 & 75.68 & 74.45 & 73.05 & 72.59 & 72.36 \\
\hline Other checkable deposits & 10.33 & 10.64 & 10.38 & 10.45 & 10.98 & 12.33 & 13.15 & 13.31 & 12.37 & 11.75 \\
\hline Savings (including MMDAs) & 23.30 & 21.92 & 19.51 & 18.73 & 19.35 & 22.10 & 23.55 & 23.23 & 20.41 & 19.56 \\
\hline Small-denomination time deposits & 29.56 & 30.98 & 33.66 & 35.37 & 35.85 & 32.85 & 30.10 & 28.83 & 30.92 & 31.28 \\
\hline Large-denomination time deposits & 11.16 & 11.27 & 11.38 & 11.17 & 10.15 & 8.40 & 7.65 & 7.68 & 8.89 & 9.77 \\
\hline Gross federal funds purchased and RPs & 1.27 & 1.35 & 1.35 & 1.36 & 1.31 & 1.36 & 1.44 & 1.89 & 1.78 & 1.70 \\
\hline Other $\ldots \ldots \ldots \ldots \ldots \ldots \ldots \ldots \ldots \ldots \ldots$ & .73 & .75 & .78 & .67 & .68 & .72 & .91 & 1.16 & 1.25 & 1.41 \\
\hline Non-interest-bearing liabilities & 15.34 & 14.67 & 14.31 & 13.57 & 12.98 & 13.24 & 13.75 & 14.24 & 14.30 & 14.23 \\
\hline Demand deposits in domestic offices & 14.23 & 13.58 & 13.09 & 12.37 & 11.83 & 12.23 & 12.82 & 13.34 & 13.23 & 13.12 \\
\hline Revaluation losses on off-balance-sheet items ${ }^{3}$ & n.a. & n.a. & n.a. & n.a. & n.a. & n.a. & n.a. & $*$ & $*$ & $*$ \\
\hline Other $\ldots \ldots \ldots \ldots \ldots \ldots \ldots \ldots \ldots \ldots \ldots \ldots \ldots \ldots \ldots$ & 1.11 & 1.09 & 1.22 & 1.21 & 1.15 & 1.01 & .93 & .90 & 1.07 & 1.10 \\
\hline Capital account & 8.26 & 8.39 & 8.56 & 8.60 & 8.62 & 8.93 & 9.37 & 9.57 & 9.97 & 10.19 \\
\hline \multicolumn{11}{|l|}{ Мемо } \\
\hline Commercial real estate loans & n.a. & n.a. & n.a. & n.a. & 11.03 & 11.08 & 11.38 & 12.10 & 12.77 & 13.26 \\
\hline Other real estate owned ... & .63 & .65 & .63 & .61 & .66 & .65 & .52 & .35 & .25 & .20 \\
\hline Managed liabilities $\ldots \ldots \ldots \ldots$ & 13.14 & 13.34 & 13.53 & 13.24 & 12.18 & 10.53 & 10.06 & 10.81 & 12.04 & 12.99 \\
\hline $\begin{array}{l}\text { Average net consolidated assets } \\
\text { (billions of dollars) } \ldots \ldots \ldots\end{array}$ & 659 & 654 & 662 & 681 & 695 & 697 & 688 & 679 & 667 & 661 \\
\hline
\end{tabular}




\section{A.2.-Continued}

E. Banks not ranked among the 1,000 largest by assets

\begin{tabular}{|c|c|c|c|c|c|c|c|c|c|c|}
\hline Item & 1987 & 1988 & 1989 & 1990 & 1991 & 1992 & 1993 & 1994 & 1995 & 1996 \\
\hline & \multicolumn{10}{|c|}{ Effective interest rate (percent) ${ }^{4}$} \\
\hline \multicolumn{11}{|l|}{ Rates earned } \\
\hline Interest-earning assets & 9.54 & 9.76 & 10.50 & 10.32 & 9.64 & 8.43 & 7.62 & 7.58 & 8.39 & 8.35 \\
\hline Taxable equivalent & 9.87 & 10.01 & 10.72 & 10.52 & 9.82 & 8.59 & 7.78 & 7.73 & 8.54 & 8.50 \\
\hline Loans and leases, gross & 10.87 & 11.03 & 11.76 & 11.60 & 11.03 & 9.83 & 9.13 & 9.01 & 9.85 & 9.78 \\
\hline Net of loss provisions & 9.60 & 9.99 & 10.86 & 10.65 & 10.09 & 9.05 & 8.62 & 8.66 & 9.44 & 9.35 \\
\hline Securities $\ldots \ldots \ldots \ldots \ldots$. & 7.93 & 7.93 & 8.37 & 8.42 & 8.03 & 6.99 & 5.92 & 5.61 & 6.10 & 6.10 \\
\hline Taxable equivalent & 8.93 & 8.64 & 9.01 & 8.99 & 8.53 & 7.40 & 6.33 & 5.99 & 6.50 & 6.52 \\
\hline Investment account. & 7.92 & 7.92 & 8.36 & 8.41 & 8.03 & 6.99 & 5.93 & 5.61 & 6.10 & 6.10 \\
\hline U.S. government and other debt & 8.05 & 8.01 & 8.51 & 8.59 & 8.19 & 7.06 & 5.91 & 5.60 & 6.19 & 6.22 \\
\hline State and local .............. & 7.53 & 7.57 & 7.57 & 7.46 & 7.17 & 6.71 & 6.09 & 5.69 & 5.64 & 5.44 \\
\hline Equity $^{2} \ldots \ldots \ldots \ldots \ldots \ldots$ & n.a. & n.a. & 8.19 & 8.34 & 7.13 & 5.63 & 5.16 & 5.52 & 6.29 & 6.06 \\
\hline Trading account & 9.04 & 14.88 & 14.84 & 12.13 & 8.52 & 7.12 & 4.83 & 6.03 & 6.09 & 6.49 \\
\hline Gross federal funds sold and reverse RPs & 6.82 & 7.68 & 9.25 & 8.12 & 5.66 & 3.51 & 2.95 & 4.09 & 5.97 & 5.34 \\
\hline Interest-bearing balances at depositories . & 7.38 & 8.07 & 9.12 & 8.55 & 7.36 & 5.60 & 4.53 & 4.64 & 5.89 & 6.12 \\
\hline \multicolumn{11}{|l|}{ Rates paid } \\
\hline Interest-bearing liabilities & 6.20 & 6.41 & 7.16 & 7.02 & 6.18 & 4.44 & 3.54 & 3.49 & 4.47 & 4.49 \\
\hline Interest-bearing deposits & 5.38 & 5.57 & 6.24 & 6.13 & 5.39 & 3.82 & 3.00 & 2.91 & 3.76 & 3.82 \\
\hline In foreign offices .... & 7.29 & 7.62 & 9.35 & 7.57 & 5.95 & 3.97 & 2.91 & 3.92 & 5.73 & 11.30 \\
\hline In domestic offices . & 5.38 & 5.57 & 6.24 & 6.13 & 5.38 & 3.82 & 3.00 & 2.91 & 3.76 & 3.82 \\
\hline Other checkable deposits & 4.93 & 4.99 & 5.09 & 5.02 & 4.61 & 3.14 & 2.42 & 2.30 & 2.50 & 2.41 \\
\hline Savings (including MMDAs) & 5.37 & 5.48 & 5.81 & 5.74 & 5.18 & 3.62 & 2.91 & 2.83 & 3.32 & 3.24 \\
\hline Large-denomination CDs ... & 6.57 & 7.13 & 8.36 & 7.92 & 6.74 & 4.90 & 3.96 & 4.12 & 5.56 & 5.50 \\
\hline Other time deposits ...... & 6.97 & 7.17 & 8.03 & 7.88 & 6.98 & 5.36 & 4.39 & 4.28 & 5.52 & 5.60 \\
\hline \multirow[t]{2}{*}{ Gross federal funds purchased and RPs } & 6.26 & 6.79 & 8.51 & 8.03 & 5.71 & 3.74 & 3.17 & 4.12 & 5.61 & 5.08 \\
\hline & \multicolumn{10}{|c|}{ Income and expense as a percentage of average net consolidated assets } \\
\hline Gross interest income & 8.72 & 8.95 & 9.65 & 9.51 & 8.92 & 7.79 & 7.05 & 7.02 & 7.79 & 7.75 \\
\hline Taxable equivalent & 9.02 & 9.17 & 9.85 & 9.68 & 9.07 & 7.94 & 7.19 & 7.16 & 7.92 & 7.88 \\
\hline Loans .............. & 5.82 & 6.01 & 6.53 & 6.44 & 6.05 & 5.30 & 4.91 & 4.99 & 5.64 & 5.67 \\
\hline Securities & 2.19 & 2.21 & 2.33 & 2.38 & 2.40 & 2.24 & 1.96 & 1.84 & 1.86 & 1.80 \\
\hline Gross federal funds sold and reverse RPs & .47 & .47 & .57 & .53 & .34 & .18 & .14 & .15 & .25 & .24 \\
\hline Other $\ldots \ldots \ldots \ldots \ldots \ldots \ldots \ldots \ldots \ldots \ldots$ & .25 & .26 & .23 & .17 & .12 & .07 & .05 & .04 & .04 & .04 \\
\hline Gross interest expense & 4.72 & 4.91 & 5.50 & 5.44 & 4.83 & 3.45 & 2.72 & 2.65 & 3.38 & 3.39 \\
\hline Deposits ............. & 4.58 & 4.76 & 5.32 & 5.28 & 4.71 & 3.36 & 2.63 & 2.52 & 3.20 & 3.22 \\
\hline Gross federal funds purchased and RPs & .08 & .10 & .12 & .11 & .07 & .05 & .04 & .07 & .10 & .08 \\
\hline 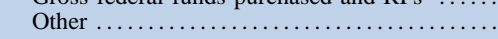 & .06 & .06 & .06 & .05 & .05 & .04 & .04 & .06 & .08 & .08 \\
\hline Net interest income & 4.01 & 4.04 & 4.15 & 4.07 & 4.09 & 4.34 & 4.33 & 4.36 & 4.41 & 4.37 \\
\hline Taxable equivalent & 4.30 & 4.26 & 4.34 & 4.24 & 4.24 & 4.49 & 4.47 & 4.50 & 4.54 & 4.49 \\
\hline Loss provisioning 5 & .68 & .56 & .50 & .53 & .51 & .42 & .27 & .19 & .23 & .25 \\
\hline Noninterest income & .88 & .92 & 1.00 & 1.01 & 1.08 & 1.16 & 1.25 & 1.30 & 1.38 & 1.42 \\
\hline Service charges on deposits & .41 & .41 & .41 & .42 & .44 & .45 & .45 & .44 & .44 & .44 \\
\hline Income from fiduciary activities & .11 & .12 & .14 & .14 & .14 & .16 & .16 & .17 & .22 & .19 \\
\hline Trading income $. . . . . \ldots \ldots . .$. & $*$ & $*$ & .01 & .01 & .01 & .01 & .01 & $*$ & .01 & $*$ \\
\hline Other $\ldots \ldots \ldots \ldots \ldots \ldots \ldots \ldots \ldots$ & .35 & .39 & .44 & .44 & .49 & .55 & .64 & .69 & .71 & .78 \\
\hline Noninterest expense & 3.43 & 3.44 & 3.48 & 3.49 & 3.60 & 3.67 & 3.73 & 3.78 & 3.80 & 3.69 \\
\hline Salaries, wages, and employee benefits & 1.62 & 1.62 & 1.65 & 1.64 & 1.65 & 1.69 & 1.72 & 1.75 & 1.80 & 1.77 \\
\hline Expenses of premises and fixed assets & .52 & .51 & .51 & .49 & .49 & .49 & .48 & .49 & .50 & .49 \\
\hline 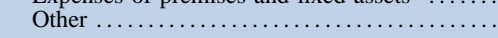 & 1.30 & 1.32 & 1.33 & 1.36 & 1.47 & 1.49 & 1.53 & 1.55 & 1.51 & 1.43 \\
\hline Net noninterest expense & 2.56 & 2.53 & 2.49 & 2.48 & 2.53 & 2.51 & 2.48 & 2.48 & 2.42 & 2.27 \\
\hline Realized gains on investment account securities . & .03 & .01 & .01 & * & .06 & .09 & .07 & -.03 & * & .01 \\
\hline Income before taxes and extraordinary items & .81 & .95 & 1.18 & 1.06 & 1.10 & 1.50 & 1.64 & 1.66 & 1.76 & 1.85 \\
\hline Taxes $\ldots \ldots \ldots \ldots \ldots \ldots$ & .25 & .29 & .37 & .34 & .35 & .47 & .51 & .51 & .55 & .59 \\
\hline Extraordinary items & .02 & .02 & .02 & .02 & .01 & .02 & .05 & $*$ & $*$ & $*$ \\
\hline Net income (return on assets) & .58 & .68 & .83 & .74 & .77 & 1.04 & 1.19 & & & \\
\hline Cash dividends declared ... & .40 & .46 & .52 & .49 & .47 & .51 & .56 & .57 & .62 & .64 \\
\hline Retained income ........... & .18 & .21 & .30 & .24 & .30 & .53 & .63 & .58 & .02 & .62 \\
\hline Memo: Return on equity & 6.99 & 8.09 & 9.66 & 8.60 & 8.95 & 11.64 & 12.66 & 12.03 & 12.12 & 12.38 \\
\hline
\end{tabular}

* In absolute value, less than 0.005 percent.

n.a. Not available. MMDA Money market deposit account. RP Repurchase agreement. CD Certificate of deposit.

1. Includes allocated transfer risk reserve.

2. As in the Call Report, equity securities are combined with "other debt securities" before 1989.

3. Before 1994, the netted value of off-balance-sheet items appeared in "trading account securities" if a gain and "other non-interest-bearing liabilities" if a loss.

4. Where possible, based on the average of quarterly balance sheet data reported on schedule RC-K of the quarterly Call Report.

5. Includes provisioning for allocated transfer risk. 